\title{
Avaliação de Técnicas de Captura para Sistemas Detectores de Intrusão
}

\author{
Dalton Matsuo Tavares
}

\begin{abstract}
Monografia apresentada ao Instituto de Ciências Matemáticas e de Computação ICMC/USP - para a defesa de mestrado, como parte dos requisitos para a obtenção do título de Mestre na Área de Ciências de Computação e Matemática Computacional.
\end{abstract}

Orientador: Prof. Dr. Edson dos Santos Moreira

\section{São Carlos/SP}

Abril/2002 



\section{Agradecimentos}

Esse espaço é dedicado a elogiar e destacar a participação de todos aqueles que tiveram algum grau de participação com o desenvolvimento deste trabalho. Como de costume, começo agradecendo a Deus por ter me dado a inspiração necessária', paciência e perseverança para que eu pudesse concluir da melhor forma possível esse trabalho. Em seguida, agradeço ao apoio de meus pais, pois sem eles, francamente, eu nunca teria chegado aqui. Agradeço ao meu orientador, professor Edson dos Santos Moreira por ter me dado a oportunidade de trabalhar com a subárea de computação que mais aprecio: segurança computacional. Com isso, pude dar continuidade ao trabalho que venho desenvolvendo desde a graduação enfocando sistemas detectores de intrusão (SDIs). Como todo bom trabalho tem sempre uma conseqüência, acabei perturbando muito meus amigos do grupo de segurança, para o esclarecimento de minhas (infindáveis) dúvidas, principalmente relativas a parte prática do projeto. Nesse espaço, não posso deixar de lembrar de Mauro César Bernardes e Stênio Firmino Pereira Filho; companheiros de trabalho e acima de tudo amigos das horas difíceis (e boas também). Também devo agradecer a Adenilso da Silva Simão, grande guru do $\mathrm{ET}_{\mathrm{E}} \mathrm{X}$ do Laboratório de Engenharia de Software (LABES); e uma das principais influências para a composição da dissertação usando esse formatador de texto.

A todos aqueles que me ouviram e por conseguinte, aturaram os meus delírios nesses últimos meses (devido a pressão), gostaria de expressar o meu mais sincero obrigado! Assim, não corro o risco de esquecer ninguém!

\footnotetext{
${ }^{1}$ Falando em inspiração necessária, não poderia deixar de mencionar alguns ícones que foram peças chave nos momentos de dificuldade... Essas entidades cósmicas são Homer Simpson, um exemplo para a compreensão de situações difíceis e Sr. Madruga, baluarte da força e da virtude.
} 


\section{Sumário}

1 Introdução 1

1.1 Histórico do grupo . . . . . . . . . . . . . . . . 2

1.2 Escopo do trabalho . . . . . . . . . . . . . . . . 3

1.3 Estrutura da dissertação . . . . . . . . . . . . . . . . . 3

2 Segurança Computacional

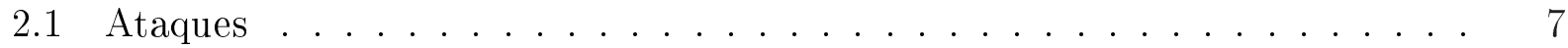

2.1.1 Tipos de ataques mais freqüentes . . . . . . . . . . . 8

2.1.1.1 Ataques de Sondagem ............. 8

2.1.1.2 Ataques de comprometimento de recurso . . . . . . . . . 9

2.1.1.3 Ataques de penetração . . . . . . . . . . . 10

2.1.2 Determinando a localização de um atacante . . . . . . . . . . 10

2.2 Vulnerabilidades . . . . . . . . . . . . . . . . . 11

2.2.1 Erro de validação de entrada . . . . . . . . . . . . . 11

2.2.2 Erros de validação de acesso. . . . . . . . . . . . . 12

2.2 .3 Convenções de nome . . . . . . . . . . . . . . . 13

2.3 Ferramentas Defensivas . . . . . . . . . . . . . 13

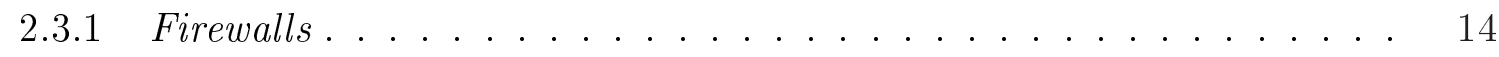

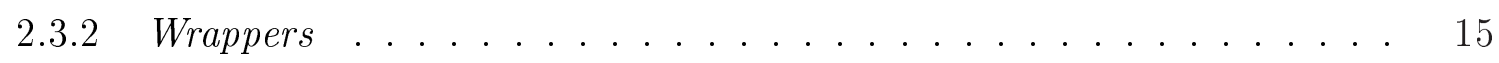

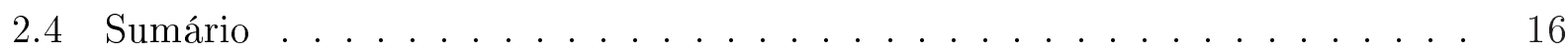

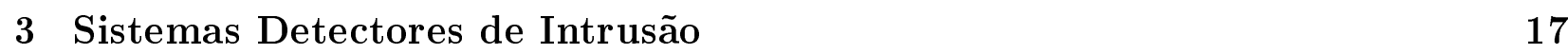

3.1 Detecção de Intrusão . . . . . . . . . . . . . . . . . . . . 18

3.1 .1 Modelo genérico para SDIs . . . . . . . . . . . 18

3.1.2 Modelos baseados em fontes de informação . . . . . . . . . . . 19

3.1.3 Modelos baseados em análise . . . . . . . . . . . . 22

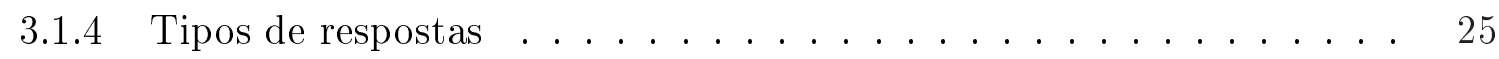

3.1.5 Considerações sobre a segurança do SDI . . . . . . . . . . . . 25

3.2 Ferramentas que complementam a ação do SDI . . . . . . . . . . . 26

3.3 Características desejáveis de um SDI . . . . . . . . . . . . . . 29 
3.4 Detecção de intrusão centralizada e distribuída . . . . . . . . . . . . . . 31

3.4.1 Comparação entre SDIs centralizados e distribuídos . . . . . . . . . 31

3.5 Sumário . . . . . . . . . . . . . . . . . . . 32

4 Agentes $\quad 35$

4.1 Breve introdução a tecnologia de agentes . . . . . . . . . . . 35

4.1.1 Utilizando agentes autônomos na construção de um SDI distribuído • 36

4.1.2 Taxonomia dos Agentes . . . . . . . . . . . . . 39

4.2 Agentes Móveis . . . . . . . . . . . . . . . . 41

4.2.1 O modelo de comunicação dos aglets . . . . . . . . . . 42

4.2.1.1 A camada de comunicação . . . . . . . . . . . . . 42

4.2.1.2 API de comunicação . . . . . . . . . . . 43

4.2.1.3 Protocolo de transferência de agentes . . . . . . . . . . 43

4.3 Sumário . . . . . . . . . . . . . . . . . . . . . 45

5 Arquitetura do sistema: original e novas inclusões $\quad 47$

5.1 Estrutura original do modelo . . . . . . . . . . . . . . 47

5.2 Ambiente de implementação do modelo . . . . . . . . . . . . . . 50

5.3 Novas inclusões ao sistema: camada de agentes de vigilância . . . . . . . . 50

5.3 .1 Agente de interface . . . . . . . . . . . . . . 51

5.3 .2 Agente de verificação de hospedeiros . . . . . . . . . . . 52

5.3.3 Agentes de verificação de usuários conectados ao sistema . . . . . . 54

5.3 .4 Agentes de verificação de usuários suspeitos . . . . . . . . . . 55

5.3.5 Agentes de sondagem (scanning) . . . . . . . . . . 55

5.3.6 Agente especializado em identificação de backdoors . . . . . . . . . 56

5.3 .7 Agente de verificação de serviços . . . . . . . . . . . . 57

5.3.8 Agente de validação de serviços . . . . . . . . . . . . . 57

5.3 .9 Agente de monitoria de serviços . . . . . . . . . . . . 57

5.3 .10 Agente de verificação de utilização de recursos do sistema . . . . . . . 58

5.3 .11 Agentes de configuração de profiles . . . . . . . . . . . . 58

5.3 .12 Agente de pré-seleção de dados . . . . . . . . . . . . . 59

5.3.12.1 Proposta para a detecção preliminar dos ataques . . . . . 60

5.3.13 Agente de captura de pacotes . . . . . . . . . . . 65

5.3.13.1 BSD Packet Filter . . . . . . . . . . . . . . 66

5.3.13.2 Biblioteca de captura - libpcap . . . . . . . . . 68

5.3.13.3 Mensagens de comunicação entre o agente de captura e o agente de pré-seleção de dados . . . . . . . . . . 70

5.3 .14 Comportamento do sistema . . . . . . . . . . . 71 
5.4 Considerações sobre a arquitetura descrita . . . . . . . . . . . . 72

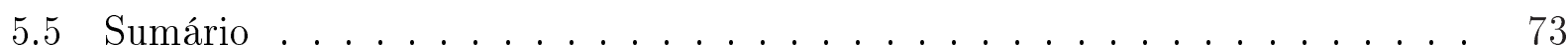

6 Infraestrutura de hardware e sua influência no sistema $\quad 75$

6.1 Agente de captura baseado em análise de vulnerabilidades . . . . . . . . 75

6.1.1 Vulnerabilidades de switches . . . . . . . . . . . 76

6.1.1.1 ARP Spoofing. . . . . . . . . . . . 77

6.1.1.2 MAC Flooding . . . . . . . . . . . . . 77

6.1.1.3 MAC Duplicating . . . . . . . . . . . . . 77

6.1.2 Considerações sobre as técnicas de ataque descritas . . . . . . . . 78

6.1.3 Mecanismos de proteção contra os ataques descritos . . . . . . . . 79

6.1.3.1 Algoritmos de Spanning Tree ............. 79

6.1.3.2 IP Filtering . . . . . . . . . . . . . . 79

6.1.3.3 Port Security . . . . . . . . . . . . 79

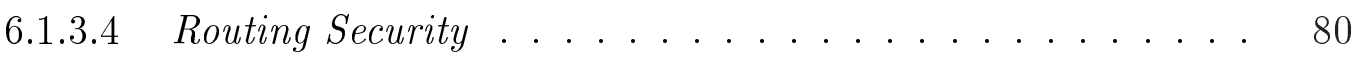

6.2 Descrição dos recursos do switch . . . . . . . . . . . . . . . 80

6.2.1 Características do sistema inerentes aos switches . . . . . . . . 81

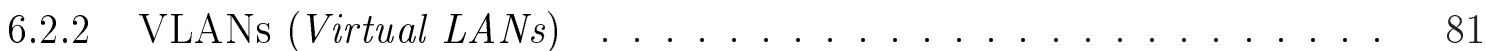

6.2.2.1 Características de VLANs . . . . . . . . . 82

6.2.3 Portas de captura ou espelhamento (Port mirroring) . . . . . . . 83

6.2.4 Outras características do switch - Módulos SDIs . . . . . . . . . 86

6.3 Sumário . . . . . . . . . . . . . . . . . . . 87

7 Conclusões e Proposta para Trabalhos Futuros $\quad 89$

7.1 Modelagem do SDI como um sistema de informação . . . . . . . . . . . . . 91 


\section{Lista de Figuras}

4.1 HTTP tunneling do ATP. . . . . . . . . . . . . . . . . . . 44

5.1 Arquitetura de um sistema de agentes móveis. . . . . . . . . . . . . . . 48

5.2 Representação do vetor de monitoração. . . . . . . . . . . . . . . . 61

5.3 Representação da Tabela de Controle de Conexões (TCC). . . . . . . . . . . 64

5.4 Estrutura interna da TCC. . . . . . . . . . . . . . . . . . . 64

5.5 Funcionamento do BPF. . . . . . . . . . . . . . . . 67

5.6 Exemplo de uma execução do agente de captura (Tavares et al., 2002). . . . 71

6.1 Posicionamento da estação de captura . . . . . . . . . . . . . . . . . . . 84

6.2 Mapeamento de pacote encapsulado pelo 802.1q. . . . . . . . . . . 85 


\section{Lista de Tabelas}

3.1 Comparação entre SDIs centralizados e distribuídos com respeito as características desejáveis descritas na seção 3.3. . . . . . . . . . . . . . .

3.2 Comparação entre SDIs centralizados e distribuídos com respeito as características desejáveis descritas na seção 3.3 (continuação) . . . . . . . . . . . . . 34

5.1 Valores de NS, referentes as portas, adotados no agente de pré-seleção para determinar o disparo automático do agente de captura. . . . . . . . . . . . 


\section{Resumo}

O objetivo principal do presente trabalho é apresentar uma proposta que permita a combinação entre uma solução de captura de pacotes já existente e não muito flexível (sniffer) e o conceito de agentes móveis para aplicação em redes segmentadas. Essa pesquisa possui como foco principal a aplicação da técnica captura de pacotes em SDIs network based, utilizando para isso o modelo desenvolvido no ICMC (Cansian, 1997) e posteriormente adequado ao ambiente de agentes móveis (Bernardes, 1999). Assim sendo, foi especificada a camada base do ambiente desenvolvido em (Bernardes, 1999) visando as interações entre seus agentes e o agente de captura de pacotes.

\section{Abstract}

The main objective of the current work is to present a proposal that allows the combination between an existent and not so flexible packet capture solution (sniffer) and the concept of mobile agents for application in switched networks. This research focuses the application of the packet capture technique in IDSs network-based, using for this purpose the model developed at ICMC (Cansian, 1997) and later adjusted to the mobile agents environment (Bernardes, 1999). Therefore, the base layer of the developed environment (Bernardes, 1999) was specified focusing the interactions between its agents and the packet capture agent. 
A necessidade por segurança computacional tem se intensificado nos últimos anos. Relatórios fornecidos por entidades confiáveis (maiores detalhes no capítulo 2) indicam um aumento considerável na ocorrência de ataques. Em decorrência deste ambiente computacional cada vez mais hostil, administradores de sistema e gerentes de segurança tem dedicado uma parcela crescente de seu tempo ao estudo da taxonomia dos ataques (a forma pela qual os ataques são levados a termo) para que possam desenvolver mecanismos de prevenção.

A conseqüência destes estudos levou ao desenvolvimento de um amplo conjunto de ferramentas de segurança; muitas das quais são baseadas em técnicas utilizadas inicialmente em ataques. Infelizmente, as ferramentas tradicionais não tem sido suficientes para conter o surgimento crescente de ataques sofisticados, desencadeados por indivíduos que são verdadeiros estudiosos do assunto. Isto tem levado a uma pesquisa mais arrojada das atividades intrusivas para que esta ameaça seja debelada.

Um exemplo de ataque mais sofisticado são os famigerados ataques distribuídos, difíceis de serem rastreados e comprovados a tempo de evitar prejuízos à corporação. A descoberta de vulnerabilidades em sistemas computacionais tem ocorrido a uma velocidade alarmante, sendo que estas podem pertencer a classes variadas. Em resposta a esses novos tipos de ataques, foi estabelecido um novo paradigma para o desenvolvimento de ferramentas de segurança: os sistemas detectores de intrusão (SDIs). Esta é uma classe de ferramentas defensivas mais flexíveis, com o potencial necessário para identificar um amplo conjunto de ataques. 


\subsection{Histórico do grupo}

Para atender a demanda por novas tecnologias de segurança, o grupo de segurança da informação (GSI) do laboratório intermídia tem estudado arduamente as tecnologias utilizadas para o desenvolvimento de SDIs, sendo esse, um dos principais focos de pesquisa atualmente. O SDI desenvolvido no ICMC evoluiu significativamente desde o início do projeto; sendo possível destacar, pelo menos, 4 fases bem definidas:

1. Projeto MultiView - implementado através da integração de várias ferramentas existentes em Unix (gawk, ping, etherfind, etc.) e estruturas de dados complexas em um ambiente gráfico bastante robusto e capaz de visualizar topologias de rede, mostrar informações de sub-redes e de equipamentos (Oda, 1994). Nessa fase, ocorreu ainda, a adição de recursos multimídia para vídeo-conferência (Lieira, 1995) (Moraes, 1995) e o desenvolvimento de um agente SNMP (Cicilini, 1994).

2. Projeto NetTracker - resultado da evolução do modelo de gerenciamento incluindo administração via WWW, método de extensão dos serviços do gerente e carregamento dinâmico de módulos (Mouro, 1997) (Mouro et al., 1997). A implementação foi feita em linguagem Java e uma implementação de SNMPv2 deveria ter sido integrada. Entretanto, os órgãos de padronização e o mercado abandonaram aquele padrão e lançaram uma nova versão: o SNMPv3, que possui características de modularidade semelhantes ao NetTracker (Morishita, 1997).

3. A terceira fase, consistiu na integração de serviços de detecção de intrusos baseado em redes neurais (Cansian, 1997) (Bonifácio, 1998). Este sistema foi concebido para ser utilizado através do ambiente NetTracker.

4. Em sua fase mais extensa (que perdura até os dias atuais), as pesquisas do grupo de segurança tem visado o emprego da tecnologia de agentes móveis a sistemas detectores de intrusão.

A princípio, foi especificado e desenvolvido um protótipo de ambiente de gerenciamento de segurança apoiado por agentes móveis (Reami, 1998). Posteriormente, foi apresentada uma proposta de modelagem (Bernardes, 1999) para as especificações introduzidas em (Reami, 1998). Em (Bernardes, 1999) foram modelados alguns cenários de utilização do ambiente, além da implementação de um deles para a verificação de anomalias.

Para uma visão mais apurada da tecnologia de agentes, foi desenvolvida uma pesquisa contendo uma avaliação detalhada de ambientes servidores para agentes móveis (Pereira Filho, 2001) cujo objetivo foi estabelecer as bases de comparação entre os diversos ambientes disponíveis. Paralelamente foi desenvolvido um trabalho considerando as diversas tecnologias que podem ser usadas para conferir inteligência a agentes móveis (Ambrósio, 2002). 


\subsection{Escopo do trabalho}

O presente trabalho tem por objetivo propor mecanismos de integração para as tecnologias de detecção de intrusão propostas anteriormente no grupo de pesquisa (notadamente na fase 4 do projeto) e os dispositivos de segmentação de redes (switches). Estas ferramentas relativamente novas tem provado seu valor ao facilitar o gerenciamento de grandes sites, através do estabelecimento de uma hierarquia de rede. Isso propicia o aumento da largura de banda, além de um acréscimo ao nível de segurança da rede (observe que esta não representa sua função principal). Os switches firmaram-se como ferramenta de uso difundido, embora tenham imposto algumas barreiras às atividades de gerenciamento de segurança da rede.

A dificuldade referente ao gerenciamento de segurança em switches ocorre devido aos problemas de integração das ferramentas de monitoramento existentes em domínios segmentados. Para o escopo deste documento, a classe de ferramentas em questão refere-se aos sistemas detectores de intrusão (SDIs). A maioria dos atuais SDIs comerciais e acadêmicos desenvolvidos para proteção de redes limitam-se a análise de tráfego em meiobroadcast. Como isso não é possível em redes chaveadas, deve-se propor um novo paradigma de desenvolvimento para SDIs com o objetivo de possibilitar sua utilização juntamente com os dispositivos de chaveamento.

A base para a discussão será o sistema proposto inicialmente em (Cansian, 1997) e cujo desenvolvimento teve sua continuidade em (Tavares et al., 1999). Este sistema (assim como a grande totalidade dos sistemas comerciais) encontra-se limitado a aplicação em redes broadcast. Serão apresentados os resultados referentes as soluções propostas para a integração do sistema detector de intrusão e os switches utilizando as tecnologias de agentes móveis estudadas ao longo da fase de pesquisa atual.

A tecnologia de agentes móveis utilizada foi baseada nos resultados obtidos em (Pereira Filho, 2001) e, no modelo arquitetural utilizado e inspirado no modelo descrito em (Bernardes, 1999).

\subsection{Estrutura da dissertação}

Os próximos capítulos irão estabelecer as bases para a discussão do sistema proposto. Os capítulos 2, 3 e 4 possuem apenas caráter informativo visando contextualizar o presente trabalho e fornecer as bases necessárias para o melhor entendimento do leitor em seções posteriores. Os demais capítulos descrevem o trabalho desenvolvido para o projeto de mestrado seguindo a estratégia:

- Definição da arquitetura do sistema; 
- Desenvolvimento e acréscimos ao modelo adotado;

- Considerações sobre a implementação do modelo e;

- Propostas para trabalhos futuros.

Nos seguintes parágrafos encontra-se o resumo do conteúdo dos demais capítulos da dissertação e a ordem seguida para alcançar as metas descritas:

O capítulo 2 terá por objetivo apresentar a motivação para justificar os esforços crescentes no campo de segurança computacional.

O capítulo 3 apresentará uma forte base para a discussão da tecnologia de sistemas detectores de intrusão. Serão abordados vários pontos dessa arquitetura, principalmente as características relacionadas a sistemas centralizados e distribuídos

O capítulo 4 refere-se a tecnologia de agentes móveis. Os conceitos definidos nesse capítulo serão de suma importância para as discussões posteriores relativas ao sistema especificado.

O capítulo 5 descreve a abordagem recentemente utilizada para a estruturação do sistema detector de intrusão do ICMC, utilizando a tecnologia de agentes móveis descrita em (Bernardes, 1999) e previamente avaliada em (Pereira Filho, 2001). O foco principal da discussão é o agente responsável pela captura de pacotes da rede embora todos os agentes presentes na primeira camada do sistema tenham sido especificados.

O capítulo 6 desenvolve uma discussão relativa a arquitetura da rede na qual o sistema detector de intrusão será inserido. A tecnologia destacada nesse capítulo são os dispositivos de rede conhecidos como switches e as características mais importantes para integração ao sistema.

O capítulo 7 irá traçar as considerações finais sobre o trabalho desenvolvido em paralelo com considerações para desenvolvimento de trabalhos futuros. 


\section{Segurança Computacional}

Nos primórdios da Internet, as redes corporativas eram compostas (em sua grande maioria) por linhas privadas alugadas. Existia a figura do CPD (Central de Processamento de Dados) onde um computador central (mainframe) realizava toda a carga de processamento. As únicas formas de comunicação conhecidas eram representadas pela figura dosdumb terminals e impressoras. Os princípios de segurança eram bastante rudimentares: proteção física do mainframe e periféricos ${ }^{1}$.

Com a evolução dos sistemas computacionais (e conseqüentemente da Internet) os princípios relacionados a segurança constituíram um quadro totalmente novo. A Internet tornou-se um veículo de comunicação onde, cada canal passa a representar um foco de ataque potencial. A gama de dispositivos relacionados evoluiu enormemente. Como exemplo, podem ser citados servidores, roteadores, switches, gateways VPN, firewalls, computadores desktop e notebooks. Embora algumas destas tecnologias tenham como objetivo principal aumentar o grau de proteção da rede, indiretamente, podem introduzir vulnerabilidades que comprometam-na ainda mais.

Através deste panorama inicial, pode-se notar que os administradores de sistemas e gerentes de segurança estão travando uma verdadeira batalha com o intuito de manter seus sistemas atualizados e inacessíveis àqueles que não possuem a permissão necessária. Foi neste contexto que surgiu o conceito de Internet Warfare $^{2}$ :

\footnotetext{
${ }^{1}$ fonte: http://rr.sans.org/securitybasics/tech_dept.php (visitado em 29/01/2002).

${ }^{2} \mathrm{O}$ termo mais próximo seria 'guerrilha digital'. Entretanto, como essa terminologia não é utilizada, optou-se por manter o vocábulo em sua forma original.
} 
"Atividade na qual um ou mais indivíduos utilizam meios ilícitos com o intuito de adquirir a informação mantida por uma determinada organizaçãơ. O objetivo do ataque pode ser danificar a informação, hardware, software ou comprometer recursos. Este termo também envolve qualquer ação defensiva tomada para repelir o ataquét."

Apesar de não ser um conceito formal, é genérico o suficiente para descrever a situação referente a segurança computacional atualmente. O grau com o qual este conceito pode ser aplicado varia de acordo com a instituição sendo analisada. Em geral, o que define o nível de segurança de uma determinada organização é seu nível tecnológicớ (Anonymous, 1997). Em última análise, esse nível tecnológico reflete o valor da informação a ser protegida pela organização.

Os investimentos em segurança, alcançaram patamares bastante elevados nos últimos anos evidenciando a preocupação crescente com este campo. Estudos recentes levam a conclusão de que investir na manutenção da segurança e prevenção contra crimes digitais é muito mais vantajoso do que arcar com as despesas referentes ao comprometimento da integridade dos dados de uma organização e, principalmente, o impacto negativo relativo a imagem pública da mesma. A pesquisa de segurança produzida pelo Computer Security Institute (CSI) e pelo Federal Bureau of Investigation (FBI) no mercado americano em 2001 registrou prejuízos de quase US\$ 378 milhões com problemas de segurança da informação,valor $42 \%$ superior ao apresentado em 2000.

O problema principal registrado no Brasil refere-se ao comportamento passivo assumido pela grande maioria das instituições quando o assunto tratado é a segurança de seus dados. Como foi registrado na pesquisa anual realizada pela Modulo Security Solutions (MSS), uma das grandes empresas brasileiras atuando no ramo de segurança, o número de organizações que não tomam as devidas atitudes ou, que tomam providências inadequadas ainda é bastante elevado. Segundo a última pesquisa realizada:

- $53 \%$ tomam providências internas.

- $39 \%$ corrigem o problema.

- $23 \%$ tomam providências legais.

\section{- $8 \%$ não tomam nenhuma providência}

Essa tendência pode ser atribuída a ausência de uma política de segurança bem estruturada e a não elaboração de um plano de continuidade. Além disso, a ausência de

\footnotetext{
${ }^{3}$ No presente contexto, organização refere-se a um indivíduo, corporação ou governo

4 adaptado a partir de (Anonymous, 1997)

${ }^{5}$ Por tecnologia refere-se a todos os aspectos referentes as ferramentas empregadas, incluindo conexões de alta velocidade, software, hardware e assim por diante.

${ }^{6}$ Fonte: http://www.gocsi.com e http://www.modulo.com.br (visitado em 29/01/2002)
} 
profissionais capacitados no mercado é outra característica determinante. Uma estimativa fornecida por Stephen Northcutt afirma que 1 entre 20 profissionais de segurança possui a competência e conhecimento necessários para que possam elevar a condição de um sistema de 'desconhecida' até um nível de segurança estável?. Esses fatores em conjunto podem ser considerados os responsáveis diretos pela reincidência de ataques em alguns sites.

Uma forma de sanar este problema foram os investimentos registrados em segurança por parte das empresas nos últimos anos. O cenário, em 2001, registrava um investimento de $71 \%$ para a elaboração da política de segurança das empresas seguido por $65 \%$ destinado a capacitação de equipe técnica ${ }^{8}$. Note que o objetivo principal não é erradicar a ocorrência de incidentes de segurança, mas sim, tornar sua ocorrência menos freqüente.

Para proporcionar uma maior compreensão do leitor com relação ao cenário de segurança computacional, é necessário que seja fornecida uma breve introdução a nomenclatura e taxonomia dos ataques. O tópico é discutido de maneira sucinta proporcionando o entendimento necessário às discussões posteriores. O restante do capítulo irá descrever os principais métodos de ataque utilizados assim como algumas das ferramentas de segurança tradicionais para combatê-los. O objetivo é introduzir o contexto no qual serão inseridas as discussões futuras sobre Sistemas Detectores de Intrusão (SDIs) e agentes móveis.

\subsection{Ataques}

Muitos ataques de computador corrompem o sistema de maneira bastante específica. Por exemplo, certos ataques podem habilitar um cracker $^{9}$ a ler arquivos mas não permitem a alteração de qualquer componente do sistema. Outro tipo de ataque pode ocasionar o desligamento de certos componentes mas não o acesso a arquivos. Considerando as diversas características de ataques de computador, eles geralmente resultam em violações de quatro propriedades de segurança: disponibilidade, confidencialidade, integridade e controle. Estas violações são descritas abaixo ${ }^{10}$ :

Confidencialidade. Consiste no acesso aos dados sem autorização (implícita ou explícita) do proprietário da informação.

\footnotetext{
${ }^{7}$ fonte: http://www.giac.org/cert_dif.php (visitado em 29/01/2002)

${ }^{8}$ Para um quadro mais detalhado consulte http://www.modulo.com.br/pdf/pesq_seg_01.zip (visitado em 29/01/2002) e consulte a $7^{a}$ Pesquisa Nacional sobre Segurança da Informação.

${ }^{9} \mathrm{Um}$ cracker pode ser definido como qualquer indivíduo que utiliza conhecimentos avançados sobre computação para o comprometimento de segurança (Anonymous, 1997).

${ }^{10}$ Alguns autores mencionam a característica de não-repudiação aliada as demais; entretanto, para as discussões posteriores, ela pode ser brevemente desconsiderada.
} 
Integridade. Um ataque causa uma violação de integridade se permitir que o estado do sistema ou de qualquer outro dado residindo ou trafegando no sistema seja alterado ilegalmente.

Disponibilidade. Um ataque causa uma violação de disponibilidade se ele não permitir que um usuário autorizado (humano ou máquina) acesse um recurso particular de sistema quando, onde, e na forma que for necessário.

Controle. Um ataque causa uma violação de controle se ele garantir privilégios que violem a política de controle de acesso do sistema. Estes privilégios habilitam uma violação de confidencialidade, integridade ou disponibilidade subseqüente.

\subsubsection{Tipos de ataques mais freqüentes}

Existem três tipos de ataques reportados com mais freqüência atualmente; são eles: ataques de sondagem (scanning attacks), ataques de comprometimento de recurso (Denial of Service attacks - DoS), e ataques de penetração de sistema11. Estes ataques podem ser lançados localmente ou remotamente, utilizando uma rede para acessar o alvo. Um profissional de segurança deve entender as diferenças entre estes tipos de ataques e as medidas a serem tomadas perante cada um deles.

\subsubsection{Ataques de Sondagem}

Ocorrem quando um atacante procura um alvo na rede ou sistema através do envio de tipos diferentes de pacotes (por exemplo, um pacote IP com todos os campos vazios e apenas o campo de número de sincronia SYN preenchido). Usando as respostas enviadas pelo alvo, o atacante pode aprender sobre as características do sistema e suas vulnerabilidades. Assim, um ataque de sondagem comporta-se como uma ferramenta de identificação de alvos para um atacante.

Vale a pena observar que estes ataques não penetram ou comprometem os sistemas. Os nomes para as ferramentas que executam estas atividades são variados: network mappers, port mappers, network scanners, port scanners, ou vulnerability scanners ${ }^{12}$. Ataques de sondagem podem identificar:

- A topologia de uma rede alvo;

\footnotetext{
${ }^{11}$ Uma lista detalhada dos ataques mais utilizados encontra-se em: http://www.sans.org/top20.htm (visitado em 02/04/2002)

${ }^{12}$ Os nomes originais das ferramentas foram mantidos apenas para fins de documentação.
} 
- Os tipos de tráfego de rede permitidos através de umfirewall;

- Os hosts ativos na rede;

- Os sistemas operacionais que estes hosts estão executando;

- Algum software servidor que esteja sendo executado;

- Os números de versão de todos os softwares detectados.

Sondas de vulnerabilidade (vulnerability scanners) são tipos especiais de ferramentas que procuram falhas específicas em hosts. Assim, a execução de um programa de sondagem ${ }^{13}$, irá resultar em uma lista de hosts (endereços IPs) vulneráveis a um ataque particular.

Com esta informação, um invasor pode identificar precisamente os sistemas de uma vítima na rede alvo além de ataques específicos que possam ser usados para penetrar tais sistemas. Em outras palavras, o invasor utiliza um software de sondagem para coletar o maior número de informações sobre o alvo, antes de lançar o ataque. Infelizmente para as vítimas, como é legal entrar em um banco e vislumbrar o sistema de segurança visível, alguns advogados argumentam que é perfeitamente legal efetuar a sondagem de um computador ou rede. Do ponto de vista do invasor, eles estão procurando legalmente por recursos acessíveis publicamente na Internet.

Existem justificativas legítimas para atividades de sondagem. Os mecanismos de procura na Internet (Web search engines) podem sondar a procura de novas páginas web. Um indivíduo pode sondar a Internet em busca de músicas disponíveis em repositórios gratuitos. Fundamentalmente, o tipo de tecnologia que permite a alguém descobrir recursos disponíveis é o mesmo empregado para a análise de um sistema em busca de fraquezas (através do uso de ferramentas de análise de vulnerabilidades). Sondagens são ataques bastante comuns, sendo os precursores da maioria das tentativas de invasão. Se um indivíduo estiver conectado a Internet, é quase certo que será sondado, se não diariamente, pelo menos algumas vezes por semana ${ }^{14}$.

\subsubsection{Ataques de comprometimento de recurso}

Ataques de comprometimento de recurso (Denial of service attacks - DoS) tentam diminuir a eficiência ou desabilitar os sistemas ou serviços da rede alvo. Em certas comunidades da Internet, ataques DoS são comuns. Por exemplo, usuários deInternet relay chats engajados em disputas verbais comumente recorrem a ataques DoS para vencer discussões

\footnotetext{
${ }^{13}$ Como por exemplo o nmap encontrado em http://www.insecure.org (visitado em 29/01/2002)

${ }^{14}$ Estatísticas bastante precisas podem ser encontradas em http://www.nic.br/stats.html/ (visitado em $12 / 04 / 2002)$
} 
com seus oponentes (empregando programas que geram um fluxo intenso de mensagens). Embora sejam usados para propósitos tão triviais, ataques DoS podem ser empregados para desativar grandes organizações. Em incidentes tornados públicos, ataques DoS eram culpados pelas perdas em operações de comércio eletrônico, com os clientes impossibilitados de acessar e realizar aquisições. Existem dois tipos principais de ataques DoS: por exploração de falhas ${ }^{5}$ (flaw exploitation) e inundação ${ }^{16}$ (flooding).

Uma variante deste ataque é denominada Distributed DoS (DDoS). É resultado da manipulação conjunta de vários sites por um invasor, agindo como um grande sistema de ataque, com o intuito de sobrecarregar um determinado sistema alvo. Com isso, procura-se sobrepujar a capacidade de processamento robusta dos servidores utilizados atualmente.

\subsubsection{Ataques de penetração}

Ataques de penetração (penetration attacks) envolvem a aquisição e/ou alteração de privilégios, recursos, ou dados. Considere essas violações de integridade e controle contrastando com os ataques DoS que violam a disponibilidade de um recurso e, ataques de sondagem, que ainda não são considerados ilegais. Um ataque de penetração pode ganhar o controle de um sistema através da exploração de uma grande variedade de falhas desoftware.

\subsubsection{Determinando a localização de um atacante}

Uma forma de determinar a localização do agressor seria através de informações de sistema (system logs) geradas por wrappers, ou através da saída gerada por um sistema detector de intrusão (SDI). Enfim, a maioria das ferramentas de segurança, na ocorrência de uma situação que foge ao comportamento normal, oferecem mecanismos para detectar a origem imediata do ataque. O endereço obtido deve ser encarado com cautela, considerando que atacantes mudam seu endereço IP de forma arbitrária (o endereço não representa necessariamente o ponto de origem do ataque).

A chave para determinar a veracidade de um endereço IP, é identificar o tipo de ataque e então determinar se o agressor precisa ou não receber uma resposta enviada pela vítima. Caso o atacante lance um ataque de apenas uma via (one-way attack), como muitos ataques DoS de inundação, onde não é necessária uma resposta do alvo, os pacotes podem ser rotulados com endereços IP aleatórios. Por outro lado, quando as respostas emitidas pela vítima forem relevantes, o que geralmente é realidade em ataques de penetração, então o agressor não pode forjar seu endereço origem. Em resumo, atacantes devem usar seu endereço correto quando estiverem lançando ataques de penetração mas não quando se trata de ataques DoS.

\footnotetext{
${ }^{15}$ Consiste na exploração de falhas no software do alvo com o objetivo de causar o esgotamento de recursos.

${ }^{16}$ Enviam a um sistema ou componente de sistema mais informação do que pode processar.
} 
Vale a pena observar que existem exceções a essa regra (por exemplo, ao lidar com atacantes experientes). Um atacante pode enviar pacotes adulterados (possuindo um endereço origem falso), utilizando-se de algum mecanismo para 'grampear' a resposta gerada para o endereço falso. Isto pode ser feito sem acesso ao computador portador do endereço falso. Esta manipulação do endereço IP é chamada de IP spoofing.

\subsection{Vulnerabilidades}

Um ataque procura sempre explorar vulnerabilidades (falhas potenciais) de sistema. Esta informação é de suma importância após a ocorrência de um ataque, pois permite que o administrador de sistema pesquise e corrija a vulnerabilidade explorada. Nesta seção, serão discutidos os principais tipos de vulnerabilidades.

Muitos esquemas diferentes foram propostos para classificar vulnerabilidades, entretanto, foge ao escopo deste documento uma discussão individual mais aprofundada. De forma a simplificar a discussão, um padrão de terminologia foi utilizado (Bace and Mell, 2001). As próximas seções irão apresentar os tipos de vulnerabilidades mais comuns com base neste padrão.

\subsubsection{Erro de validação de entrada}

Os dados recebidos por um sistema não são checados de maneira apropriada, resultando em uma vulnerabilidade que pode ser explorada através do envio de uma certa seqüência de entrada. Existem dois tipos importantes de erros de validação: erros de estouro de buffer (buffer overflow) e erros de condição limite (boundary condition errors).

Erros de estouro de buffer. Em erros de estouro de buffer, a entrada recebida pelo sistema é maior do que a esperada (esta condição não é verificada). O buffer de entrada é preenchido causando sobrecarga da memória alocada. Através da construção sábia desta entrada extra, um atacante pode provocar a execução de instruções em seu nome.

Erros de condição limite. Em erros de condição limite, a entrada recebida por um sistema, seja ela gerada por humano ou máquina, excede um limite assumido. Alguns exemplos podem ser:

- O sistema pode esgotar sua memória, espaço em disco, ou largura de banda.

- Uma variável pode alcançar seu valor máximo e acabar retornando ao seu valor mínimo. 
- As variáveis em uma equação podem ser ajustadas para provocar uma divisão por zero.

Percebe-se, segundo os exemplos supra citados, que erros de estouro debuffer podem ser considerados uma subclasse de erros de condição limite. Entretanto, devido a sua importância e generalidade, os ataques de estouro debuffer são classificados em uma categoria separada.

\subsubsection{Erros de validação de acesso.}

Em um erro de validação de acesso, o sistema torna-se vulnerável devido a uma falha no mecanismo de controle de acesso e não em decorrência de um erro de configuração causado pelo usuário.

Erro de manipulação de condição causado por exceção -Neste caso, o sistema torna-se de alguma forma vulnerável devido a uma exceção que surge sob certas circunstâncias. A manipulação (ou manipulação errônea) da exceção pelo sistema habilita uma vulnerabilidade.

Erro de ambiente - O ambiente no qual um sistema está instalado torna-o vulnerável. Isto se deve, por exemplo, a uma interação inesperada entre uma aplicação e o sistema operacional ou entre duas aplicações no mesmo host. Um sistema vulnerável pode ser configurado de maneira apropriada e talvez torne o ambiente de teste dos desenvolvedores seguro. O problema é que o ambiente de instalação viola de alguma forma as premissas de segurança previamente definidos.

Erro de configuração - Um erro de configuração ocorre quando os parâmetros de configuração de um usuário são ajustados de forma que o sistema fique vulnerável. Essa vulnerabilidade não é o resultado de uma falha de projeto do sistema, mas da forma como o usuário final realizou sua configuração. Também é considerado um erro de configuração quando um sistema é enviado pelo desenvolvedor com uma configuração fraca. A prática referente a ajustes de configuração em sistemas (com o intuito de torná-los menos vulneráveis a erros de usuários e/ou configuração fraca proveniente de fabricante) denomina-searmoring ${ }^{17}$.

Condição de corrida. Ocorrem quando existe um atraso entre o momento em que o sistema verifica se uma operação é permitida pelo modelo de segurança e o momento em

\footnotetext{
${ }^{17}$ Para maiores informações consulte http://www.enteract.com/ lspitz/ (visitado em 29/01/2002).
} 
que o sistema realmente desempenha a operação. O problema real ocorre quando o ambiente encontra-se na transição entre esses dois instantes; de tal forma que o modelo de segurança não permita a operação. Atacantes podem tirar vantagem desta pequena janela de oportunidade e convencer o sistema a executar operações ilegais como por exemplo, a escrita no arquivo de senhas enquanto estiver em estado de maior privilégio.

\subsubsection{Convenções de nome}

Até recentemente, não havia uma convenção de nomes para ataques ou vulnerabilidades de computador. Isto tornou muito difícil comparar a efetividade de ferramentas de segurança considerando que cada fabricante gerava uma lista de resultados diferente ao analisar eventos que refletiam um mesmo conjunto de ataques. Isto também tornou difícil coordenar o uso de mais de um tipo de ferramenta de segurança em uma rede, já que cada uma produzia um conjunto próprio de mensagens ao detectar uma irregularidade.

Felizmente, existem esforços desempenhados por parte da comunidade de segurança de redes para desenvolver uma nomenclatura comum para ataques e vulnerabilidades de computador. A iniciativa mais conhecida é a Common Vulnerabilities and Exposures List (CVE) e é mantida pelo MITRE ${ }^{18}$ contando com a participação de profissionais de segurança distribuídos pelo mundo. Muitos fabricantes de ferramentas de segurança para rede concordaram em tornar seus produtos compatíveis com o CVE. A lista CVE pode ser procurada e visualizada usando o índice de vulnerabilidades ICAT do NIST ${ }^{19}$.

\subsection{Ferramentas Defensivas}

A categoria de ferramentas defensivas engloba uma gama bastante variada de dispositivos. Entretanto, não é o objetivo deste trabalho descrever cada uma das ferramentas disponíveis no mercado de segurança (como anti-vírus, tripwires, etc.). Algumas categorias de ferramentas serão descritas no próximo capítulo (analisadores de anomalias, verificadores de integridade e etc.), e serão utilizadas como um acréscimo às funções desempenhadas pelo SDI. Esta seção tem um objetivo mais específico: discutir ferramentas defensivas consagradas, voltadas para proteção de redes. Com isso, pretende-se conduzir a discussão para o assunto que é o tema do próximo capítulo: sistemas detectores de intrusão (SDIs).

\footnotetext{
${ }^{18}$ Para mais informações vide http://www.mitre.org (visitado em 29/01/2002).

${ }^{19}$ Fonte: http://icat.nist.gov/icat.cfm. O site principal do CVE é: http://cve.mitre.org (visitado em 29/01/2002).
} 


\subsubsection{Firewalls}

Firewalls são dispositivos que oferecem um certo grau de isolamento às máquinas de uma Intranet em relação ao mundo exterior. Esta ferramenta deve ser usada como um acréscimo as medidas de segurança de uma organização (a política de segurança não deve ser baseada unicamente neste recurso).

Posicionado em pontos estratégicos de uma rede, promove algum nível de controle sobre o tráfego que será trocado entre ambos. O termo firewall, devidamente adaptado pode ser traduzido como 'parede corta fogo'. A idéia é atrasar o progresso do fogo em caso de incêndio propiciando a chegada de ajuda. Dentro da organização, sua função seria minimizar os estragos em caso de quebra de segurança a um grupo de máquinas e não a rede inteira. Posicionado entre a organização e a Internet, previne ataques de indivíduos que tenham adquirido acesso não autorizado em algum ponto da rede.

Em geral, as premissas (ou regras) usadas em firewalls são 'permita todos os acessos' ou 'negue todos os acessos exceto os explicitamente indicados'. Esta última é um exemplo de política bastante radical mas permite um melhor controle dos acessos feitos a sites da organização. O inconveniente é que a quantidade de regras utilizadas pode ser proibitiva. No caso da $1^{a}$ proposta, apenas domínios que representem ameaças são filtrados. Apesar de mais fácil de gerenciar, esta política demanda a exposição prévia do domínio da organização (ou de algum outro domínio, considerando que este tipo de informação seja compartilhada). Isto é basicamente esperar que o criminoso bata a porta para tomar alguma atitude.

Quanto ao seu posicionamento, um firewall é colocado no ponto de intersecção entre duas redes. Além do controle de acesso proporcionado, existem uma série de propostas previstas para o seu uso:

- Restrição de acesso a determinadas máquinas ou domínio.

- Monitoramento de comunicações, através da análise do tráfego entre os pontos da rede pelo qual é responsável.

- Pode ser usado para 'grampear' comunicações entre a rede interna e a rede externa para detectar ataques de penetração ou subversão interna.

- Caso exista um firewall entre cada rede interna conectada, este pode ser usado para cifrar o tráfego entre as redes de forma a criar uma VPN.

Apesar de todas estas vantagens e aplicações, um firewall não é a solução para todos os problemas de segurança. Pode ser considerado apenas, um bom componente de segurança. Além disso, antes de depositar todas as esperanças em um firewall, vale a pena considerar algumas questões quanto a segurança oferecida pelo firewall (Garfinkel and Spafford, 1996): 
- Talvez a instalação do firewall em alguns sites tenha sido falha, ou muito permissiva.

- Talvez os usuários internos a organização encontrem maneiras para despistar ofirewall através da conexão de modems não autorizados, gerando problemas.

- Talvez a utilização de firewalls leve ao excesso de confiança e um conseqüente relaxo por parte do time de segurança.

- Talvez sites usando firewalls sejam alvos mais atraentes do que aqueles que não usem este recurso.

- Talvez, como sugerido por muitos outros estudos, a grande maioria dos incidentes continuem sendo causadas por pessoas internas a organização, e estes não possam ser parados por firewalls.

A conclusão a ser tirada a partir destas informações é que um ou maisfirewalls podem ajudar na segurança do site, mas o restante da segurança deve ser planejada de forma que os sistemas estejam protegidos em caso de uma eventual falha do firewall $^{20}$.

\subsubsection{Wrappers}

Um wrapper é um programa usado para controlar o acesso a um segundo programa. Ele literalmente 'envolve' (wraps) o programa permitindo que seu nível de segurança seja reforçado de tal forma que o programa por si só não conseguiria.

Wrappers são invenções relativamente recentes em segurança UnIX. Estes programas surgiram da necessidade de modificar os sistemas operacionais sem acesso ao código fonte do sistema.

Entretanto, seu uso tem aumentado tornando-o uma ferramenta de segurança elegante por uma série de razões:

- A lógica de segurança está encapsulada em um único programa; são simples e fáceis de validar.

- O programa protegido permanece uma entidade separada, podendo ser atualizado sem a necessidade de que o wrapper seja certificado uma segunda vez.

\footnotetext{
${ }^{20}$ Um firewall também está sujeito a ataques como qualquer outro dispositivo de segurança. Isto pode ser comprovado através dos ataques de comprometimento de recurso realizados contra o FireWall-1 produto da Check Point Software Technologies em 19 de junho de 2000 e 6 de fevereiro de 2001. Para maiores detalhes vide:

http://www.kb.cert.org/vuls/id/446689 (visitado em 29/01/2002)

http://www.kb.cert.org/vuls/id/35958 (visitado em 29/01/2002)
} 
- Wrappers chamam o programa executado através da chamada de sistemaexec(). Um único wrapper pode ser usado para controlar o acesso a uma variedade de outros programas.

- Uma função comum de um wrapper é limitar a quantidade de informação acessada por um programa com capacidade de rede. O projeto de tais programas pode assumir um excesso de confiança no meio sem a validação adequada.

\subsection{Sumário}

O objetivo desta seção foi estabelecer as bases necessárias para justificar os investimentos em segurança da informação. Para isso, foram apresentados alguns dados obtidos em pesquisas recentes realizadas no Brasil e Estados Unidos.

A ausência de uma política de segurança bem definida tem sido o principal responsável pelos prejuízos das empresas e pela falta de dados e evidências que possam ser usados para rastrear o invasor e posteriormente implicá-lo legalmente pelo ocorrido. A falta mais grave em alguns casos é a incapacidade de quantificar as perdas e determinar se com certeza as instituições foram invadidas.

A discussão relativa a ataques procurou enfocar os principais conceitos envolvidos, com o intuito de fornecer a base conceitual para discussões futuras. Também foram apresentadas algumas ferramentas tradicionais utilizadas (firewalls e wrappers) para o reforço de segurança especificamente em redes de computadores. Considerando que essas soluções estão disponíveis no mercado e já sofreram todo um processo de adaptação para o amadurecimento da tecnologia, então, o que justifica os grandes investimentos de corporações e do governo em novos paradigmas para o desenvolvimento de ferramentas; em especial sistemas detectores de intrusão (SDIs)?

A resposta mais próxima a essa pergunta é que não existe solução única quando o assunto tratado é segurança. Se considerarmos, por exemplo, o caso de um firewall, seu contexto de aplicação limita-se unicamente a proteção do perímetro da rede através da filtragem de tráfego proveniente do meio externo. Em caso de falha, o administrador levará um certo tempo até tomar consciência do ocorrido. O SDI funcionaria como um 'alarme' relatando atividades ilícitas, e conseqüentemente, complementando a ação do firewall. $\mathrm{O}$ próximo capítulo irá discutir essa classe de ferramentas em maiores detalhes procurando explicitar suas principais características. 


\section{Sistemas Detectores de Intrusão}

O campo de detecção de intrusão cresceu consideravelmente nos últimos anos, fato percebido graças ao surgimento de um grande número de Sistemas Detectores de Intrusão (SDIs) desenvolvidos com o intuito de atender a diferentes necessidades. A detecção de intrusão torna-se cada vez mais necessária devido ao crescimento considerável de sistemas computacionais conectados as redes.

Segundo (Axelsson, 2000) o campo de detecção de intrusão computacional tem sido pesquisado há aproximadamente 20 anos, mantendo o ritmo de desenvolvimento durante os últimos 10 anos. Os primeiros sistemas para detecção de intrusão em redes de computadores utilizavam uma arquitetura centralizada (ou um ponto centralizado de tomada de decisões), mesmo quando os dados coletados eram distribuídos. Mais recentemente, este paradigma tem sofrido modificações, através do desenvolvimento de SDIs descentralizados e aplicação de uma grande variedade de técnicas. Como exemplos pode-se citar oHummer (Polla et al., 1998), Emerald (Porras and Neumann, 1997), (Neumann and Porras, 1999) (que compartilhava dados entre domínios), e o AAPHID2 (Zamboni and Spafford, 2000), (Balasubramaniyan et al., 1998) (uma abordagem altamente distribuída baseada em agentes). As características de SDIs centralizados e distribuídos, assim como um estudo comparativo serão o assunto da seção 3.4

Neste capítulo serão apresentadas as bases conceituais seguidas para o desenvolvimento de SDIs e as questões mais importantes a serem consideradas em seu planejamento. Serão discutidas as vantagens e desvantagens inerentes a utilização desta tecnologia bem como os critérios utilizados pelas organizações para a escolha do SDI mais adequado. Os conceitos estabelecidos neste capítulo serão referenciados posteriormente. 


\subsection{Detecção de Intrusão}

Para o escopo deste documento, o termo detecção de intrusão pode ser definido como:

"O problema relacionado a identificação de indivíduos (possivelmente crackers) que visam a utilização de um sistema computacional sem a autorização apropriada, ou ainda, a caracterização de abuso deliberado de privilégios por parte de usuários legítimos do sistema (ameaça do usuário interno)"(Mukherjee et al., 1994).

A definição da palavra intrusão presente no dicionário', não prevê o conceito de abuso realizado por usuário interno. Este conceito foi agregado a definição presente em (Heady et al., 1990), onde esse termo é enunciado como 'qualquer conjunto de ações que tentam comprometer a integridade, confidencialidade, ou disponibilidade de um recurso', não obstante o sucesso ou falha das ações desempenhadas. Com isso, uma definição possível para sistemas detectores de intrusão seria:

"Um sistema de detecção de intrusão é representado por um sistema computacional (possivelmente uma combinação de software e hardware) que tem por objetivo executar a detecção de intrusão".

A maioria dos sistemas de detecção de intrusão tentam realizar sua tarefa em tempo real (Mukherjee et al., 1994), entretanto, existem sistemas que não possuem essa característica. Isso se deve a natureza da análise executada (Kim and Spafford, 1994) ou ainda, ao fato de serem projetados para efetuar análise forense (Farmer and Venema, 1999), (Tan et al., 1999).

\subsubsection{Modelo genérico para SDIs}

Existe uma grande variedade de SDIs disponíveis hoje, caracterizados por diferentes abordagens de monitoramento e análise. Cada abordagem tem vantagens e desvantagens distintas. Além disso, todas as abordagens podem ser descritas em termos de um modelo de processos genérico para SDIs.

Este modelo (Bace and Mell, 2001) pode ser descrito em termos de três componentes fundamentais:

\footnotetext{
${ }^{1}$ Fonte: Merriam-Webster OnLine - Webster Dictionary, http://www.m-w.com/dictionary (visitado em $31 / 01 / 2002)$.
} 
- Fontes de informação - São as diversas fontes de eventos usadas para determinar se uma intrusão realmente ocorreu. Podem ser obtidas em diferentes níveis do sistema, sendo que as mais comuns são referentes ao monitoramento de rede, computador (host) e aplicação.

- Análise - É a parte dos SDIs que realmente organiza e obtém sentido nas fontes de informação obtidas, decidindo quando os eventos descritos indicam se intrusões estão em curso ou se já ocorreram. As abordagens de análise mais comuns são 'detecção por uso indevido' e 'detecção por anomalia'.

- Resposta - É o conjunto de ações tomadas pelo sistema. Uma vez que as intrusões são detectadas, estas são agrupadas tipicamente em medidas ativas e passivas. As medidas ativas envolvem algumas intervenções automáticas por parte do sistema, e as medidas passivas fornecem o relatório das descobertas do SDI aos humanos, que são responsáveis por tomar uma ação baseada nos informes.

\subsubsection{Modelos baseados em fontes de informação}

A forma mais comum para a classificação de SDIs é através das fontes de informação utilizadas. Alguns SDIs analisam pacotes de rede, capturados de backbones ou segmentos de LAN, para rastrear atacantes. Outros SDIs analisam fontes de informações geradas pelo sistema operacional ou software de aplicação em busca de sinais de intrusão.

Esta modalidade pode ser dividida em SDIs network-based, host-based e application-based. A seguir, cada um destes modelos será descrito em detalhes.

SDIs network-based - A grande maioria dos SDIs comerciais tem como ambiente operacional as redes de computadores. Estes SDIs detectam ataques através da captura e análise dos pacotes da rede. Ao 'escutar' um segmento de rede, um SDInetwork-based pode monitorar o tráfego de múltiplos hosts.

Os SDIs network-based são compostos, geralmente, por conjuntos de sensores de propósito específico (posicionados em hosts) colocados pontos estratégicos da rede. Estas unidades monitoram o tráfego, desempenhando uma análise local e reportam ataques a um console de gerenciamento central. Como os sensores estão limitados a executar o SDI, eles podem ser mais facilmente protegidos contra ataques. Muitos destes sensores são projetados para executar em modo camuflado (stealth mode), para tornar mais difícil ao atacante determinar sua presença e localização.

Vantagens: 
- Poucos elementos bem posicionados podem monitorar uma rede extensa.

- SDIs network-based tem pequeno impacto sobre uma rede existente. São em geral dispositivos passivos com a finalidade de monitorar um segmento de rede sem interferir em sua operação normal. Assim, torna-se fácil redimensionar uma rede para a inclusão de um SDI network-based com mínimo esforço.

- Podem ser bastante seguros contra ataques além de invisíveis a muitos atacantes.

\section{Desvantagens:}

- Dependendo do fluxo de informações na rede, pode apresentar dificuldade para processá-lo, podendo falhar no reconhecimento de ataques lançados durante períodos de tráfego intenso. Alguns fabricantes estão procurando resolver este problema através da implementação de SDIs em hardware dedicado. A necessidade de analisar pacotes rapidamente também obriga os fabricantes a detectarem um maior número de ataques com o uso mínimo de recursos computacionais, o que pode levar a uma redução na efetividade da detecção.

- Muitas das vantagens de SDIs network-based não se aplicam a redes chaveadas modernas. Dispositivos denominados switches subdividem as redes em vários segmentos menores (geralmente um segmento fast Ethernet por host) fornecendo ligações dedicadas a hosts servidos pelo mesmo switch.

- SDIs network-based, de um modo geral, não podem analisar informação cifrada. Este problema está aumentando à medida que mais organizações (e atacantes) usam redes privadas virtuais (virtual private networks - VPNs).

- Muitos SDIs network-based não sabem se um ataque foi bem sucedido; apenas percebem o seu início. Isto significa que após detectar um ataque, os administradores devem investigar manualmente cada host atacado para determinar se realmente seu perímetro foi violado.

- Alguns SDIs network-based apresentam problemas para lidar com ataques distribuídos que envolvem fragmentação de pacotes. Estes pacotes mal formados podem causar a instabilidade e provável crash do SDI.

SDIs host-based - SDIs host-based operam sobre a informação coletada em um sistema computador individual. Esta vantagem permite que SDIshost-based analisem atividades com alto grau de confiabilidade e precisão, determinando exatamente que processos e usuários estão envolvidos em um ataque particular no sistema operacional. Além disso, 
diferente de SDIs network-based, SDIs host-based podem identificar os resultados de uma tentativa de ataque, pois possuem a capacidade de acessar e monitorar diretamente os arquivos de dados e processos de sistema geralmente visados pelos atacantes.

\section{Vantagens:}

- SDIs host-based, com sua habilidade de monitorar eventos locais a um host, podem reconhecer ataques não identificados por um SDI network-based.

- SDIs host-based podem operar freqüentemente em um ambiente onde o tráfego de rede é cifrado. As fontes de informação são geradas antes que os dados sejam codificados e/ou depois que os dados são decifrados no computador destino.

- SDIs host-based não são afetados por redes chaveadas.

- Quando os SDIs host-based operam sobre os registros de auditoria do SO, podem ajudar a detectar cavalos de tróia ${ }^{2}$ ou outros ataques que envolvam falhas de integridade de software. Estas aparecem como inconsistências na execução do processo.

\section{Desvantagens:}

- SDIs host-based são mais difíceis de gerenciar pois a informação deve ser configurada e gerenciada para cada host monitorado.

- Como as fontes de informação (e algumas vezes parte dos motores de análise) residem em um computador visado por atacantes, o SDI pode ser atacado e desabilitado como parte do processo.

- SDIs host-based não são bem adaptados à detecção de sondagens de rede ou outros tipos de análise que tem como alvo uma rede inteira. Reconhece apenas os pacotes de rede recebidos pelo host monitorado.

- SDIs host-based podem ser desabilitados por certos ataques de comprometimento de recurso (DoS) (Ptacek and Newsham, 1998).

- Quando SDIs host-based usam registros de auditoria do sistema operacional como fonte de informação, a quantidade de dados pode ser enorme, exigindo armazenamento local adicional no sistema.

\footnotetext{
${ }^{2}$ Programa destrutivo que é mascarado como uma aplicação benigna. Diferente dos vírus de computador, cavalos de tróia não se replicam, mas podem ser tão destrutivos quanto os vírus. Fonte: http://www.webopedia.com/TERM/T/Trojan_horse.html (visitado em 01/02/2002).

${ }^{3}$ Embora já existam procedimentos que evitem ataques desta natureza a SDIs (Paxson and Handley, 1999).
} 
- SDIs host-based usam os recursos computacionais dos hosts que estão monitorando infligindo um custo de desempenho aos mesmos.

SDIs Application-based - SDIs application-based são um subconjunto de SDIs host-based que analisam os eventos desencadeados por uma aplicação de software. As fontes de informação mais comuns usadas por SDIs application-based são os arquivos de registro $(\log s)$ contendo informações sobre as transações realizadas pela aplicação. Procuram identificar os excessos cometidos por usuários legítimos.

\section{Vantagens:}

- SDIs application-based podem monitorar a interação entre os usuários e a aplicação, o que permite freqüentemente atribuir atividade não autorizada a um determinado individuo.

- SDIs application-based podem quase sempre trabalhar em ambientes cifrados, desde que se relacionem com a aplicação ao final da transação, onde a informação é apresentada aos usuários na forma decifrada.

\section{Desvantagens:}

- SDIs application-based podem ser mais vulneráveis a ataques do que SDIs host-based. Isto se deve ao fato de as informações de aplicação não serem tão bem protegidas quanto os registros de auditoria do sistema.

- Como SDIs host-based freqüentemente monitoram eventos no nível de abstração do usuário, eles geralmente não podem detectar cavalos de tróia ou outros softwares adulterados para ataque. Assim sendo, é aconselhável usar um SDI application-based combinado a um SDI host-based e/ou network-based.

\subsubsection{Modelos baseados em análise}

Em trabalhos anteriores (Sebring et al., 1988), (Axelsson, 2000), foram identificados dois tipos principais de estratégias para detecção de intrusão:

\section{Detecção por uso indevido ou baseada em assinatura (signature-based) -} Detectores de uso indevido analisam a atividade do sistema, procurando por eventos ou conjuntos de eventos que se encaixem em um padrão pré-definido que descreva um ataque conhecido. Como os padrões correspondentes aos ataques conhecidos são chamados de 
'assinaturas' a deteç̧ão por uso indevido é também citada na literatura como detecção baseada em assinatura (signature-based). Exemplos de sistemas de deteç̧ão por uso indevido são o IDIOT (Kumar and Spafford, 1995), o STAT (Ilgun et al., 1995), além do SDI desenvolvido pelo ICMC (Cansian, 1997).

A forma mais comum de deteç̧ão de assinaturas usadas em produtos comerciais especifica cada padrão de evento correspondente a um ataque como uma assinatura separada. Entretanto, existem abordagens mais sofisticadas (chamadas de técnicas baseadas em estado ou state-based (Bace and Mell, 2001)) que podem relacionar uma assinatura a um grupo de ataques.

\section{Vantagens:}

- Detectores por uso indevido são muito efetivos na deteç̧ão de ataques sem a geração de um número exagerado de alarmes falsos (Phung, 2000).

- Podem diagnosticar de forma confiável e rápida o uso de uma ferramenta ou técnica de ataque específica. Isso pode ajudar gerentes de segurança a priorizar as medidas corretivas.

- Permitem que gerentes de sistema (sem levar em conta seu nível de habilidade) determinem problemas de segurança e iniciem procedimentos de resposta a incidentes.

Desvantagens:

- Detectores de uso indevido podem somente detectar ataques conhecidos. Assim sendo, devem ser constantemente atualizados com assinaturas de novos ataques.

- Muitos detectores de uso indevido são projetados para usar assinaturas rigidamente definidas que ocasionam a não detecção de variantes de ataques comuns. Detectores de uso indevido baseados em estado podem superar esta limitação, mas não são comumente usados em SDIs comerciais.

Deteç̧ão por anomalia - SDIs baseados em deteç̧ão por anomalia (como o IDES (Lunt et al., 1992)) concentram suas atividades na busca de perfis que fogem significativamente do comportamento normal estabelecido. Neste caso, procura-se identificar abusos de privilégios legítimos que não podem ser facilmente codificados em políticas de segurança.

Por exemplo, o perfil normal de um usuário pode conter as freqüências médias de alguns comandos do sistema usados em suas sessões. Se em uma sessão que está sendo monitorada as freqüências são significativamente menores ou maiores, então será disparado um alarme de anomalia.

Os princípios usados em deteç̧ão por anomalia incluem: 
- Detecção por limiar (threshold), na qual certos atributos do comportamento do usuário e do sistema são expressos em termos de quantidades, com alguns níveis estabelecidos como permissivos. Tais atributos de comportamento podem incluir o número de arquivos acessados por um usuário em um dado período de tempo, o número de tentativas mal sucedidas para acessar o sistema, a quantidade de CPU utilizada por um processo, etc. Este nível pode ser estático ou heurístico (i.e. projetado para mudar com os valores reais observados ao longo do tempo).

- Medidas estatísticas paramétricas, onde a distribuição de atributos do perfil é assumida de forma a se encaixar em um padrão particular, e não paramétrica, onde a distribuição de atributos do perfil são 'aprendidas' a partir de um conjunto de valores, observados ao longo do tempo.

- Medidas baseadas em regras, que são semelhantes a medidas estatísticas não paramétricas no aspecto referente aos dados observados definidos como padrões de uso aceitáveis, mas diferente, levando em consideração que aqueles padrões são especificados como regras, não quantidades numéricas.

- Outras medidas, incluindo redes neurais, algoritmos genéticos, e modelos de sistemas imunes ${ }^{4}$.

Das medidas apresentadas, apenas as duas primeiras são usadas em SDIs comerciais atualmente.

\section{Vantagens:}

- SDIs baseados em deteç̧ão por anomalia avaliam comportamento incomum, e assim, possuem a habilidade de detectar sintomas de ataques sem conhecer os detalhes específicos.

- Sistemas dessa natureza produzem informação, que por sua vez, pode ser usada para definir assinaturas para detectores de uso indevido.

\section{Desvantagens:}

- Abordagens de detecção por anomalia geralmente produzem um grande número de alarmes falsos devido aos comportamentos imprevisíveis de usuários e redes.

- Esta abordagem freqüentemente necessita de um conjunto de treinamento extenso obtido a partir de registros de eventos do sistema para caracterizar padrões de comportamento normal.

\footnotetext{
${ }^{4}$ Temas de outro trabalho do grupo de segurança (Ambrósio, 2002)
} 
- Existe a possibilidade de um atacante 'ensinar' ao sistema que suas atividades ilegítimas fazem parte do comportamento normal.

\subsubsection{Tipos de respostas}

Uma vez que as informações sobre os eventos tenham sido obtidas e analisadas para encontrar os sintomas dos ataques, são geradas as respostas. Algumas dessas respostas envolvem o relatório dos resultados e descobertas a uma localização pré estabelecida. Outras envolvem respostas automáticas. Embora pesquisadores ignorarem freqüentemente a importância de boas funções de resposta em um SDI, deve-se estar ciente de sua importância no processo de deteç̧ão.

Os tipos de resposta são classificados em:

Respostas ativas - São ações automáticas tomadas quando certos tipos de intrusões são detectadas.

Respostas passivas - SDIs de resposta passiva fornecem respostas aos usuários do sistema dependendo de humanos para a realização de ações subseqüentes. Muitos SDIs comerciais baseiam-se unicamente em respostas passivas.

\subsubsection{Considerações sobre a segurança do SDI}

Ao desenvolver um SDI, o projetista deve considerar mecanismos de proteção (failsafe features), cujo objetivo é evitar que o SDI seja despistado ou sobrepujado por um atacante. Esta é uma das diferenças fundamentais entre ferramentas de gerenciamento de sistema e ferramentas de gerenciamento de segurança. Um exemplo que justifica esta preocupação com a segurança do SDI é a transmissão de alarmes ao administrador, sem nenhuma medida que garanta a integridade e privacidade da informação. Desta forma, expõe-se em demasia a presença do sistema ao invasor de plantão.

Túneis cifrados ou outras medidas que se utilizem de criptografia para autenticar o SDI são excelentes meios de garantir a segurança e confiabilidade do sistema. Na próxima seção, será apresentado um conjunto de ferramentas cuja função é complementar a ação do SDI, e com isso, minimizar a possibilidade de exposição do mesmo a ação do invasor. 


\subsection{Ferramentas que complementam a ação do SDI}

Existem várias ferramentas que complementam a ação de um SDI e também são rotuladas como produtos de detecção de intrusão pelos fabricantes por desempenharem funções similares. Esta seção discute algumas destas ferramentas e descreve como elas podem melhorar a capacidade de detecção de intrusão da organização.

Sistemas de análise ou avaliação de vulnerabilidades- Ferramentas para análise de vulnerabilidades (também conhecidas como ferramentas de avaliação de vulnerabilidades) procuram determinar se uma rede ou host é vulnerável a ataques conhecidos. Essa técnica representa um caso especial no processo de detecção de intrusão. As fontes de informação usadas são atributos de estado do sistema resultantes de tentativas de ataque. Esses dados são coletadas por uma parte do motor de análise. O período de análise é interval-based ${ }^{5}$, e o tipo de análise é detecção por uso indevido.

O processo de análise é feito tomando-se uma amostra dos atributos do sistema, armazenando os resultados da amostra em um repositório de dados seguro e comparando-os a pelo menos um conjunto de referência tido como a configuração 'ideal' do sistema. Qualquer diferença entre os dois conjuntos é identificada e reportada.

Alguns exemplos de ferramentas que utilizam um esquema de teste baseado em vulnerabilidades do sistema são: o nmap (citado na seção 2.1.1.1), o nessus ${ }^{6}$, o saint ${ }^{7}$, o dsniff ${ }^{8}$, o satan ${ }^{9}$ entre outros. Um exemplo de ferramenta que utiliza métodos de inferência são os verificadores de rootkits ${ }^{10}$.

\section{Vantagens:}

- É de grande valor como parte do sistema de monitoramento, permitindo a detecção de problemas em sistemas que não suportam SDIs.

- Fornecem capacidades para teste de segurança específicos para documentar o estado dos sistemas no início de um programa de segurança, e para estabelecer o limite onde as maiores mudanças ocorrem.

\footnotetext{
${ }^{5}$ Em um SDI interval-based o fluxo de informação de pontos de monitoramento (um host ou sensor) para os motores de análise não é contínuo. Na realidade, a informação é manipulada de maneira semelhante a esquemas de comunicação "store and forward".

${ }^{6}$ http://www.nessus.org/ (visitado em 04/02/2002)

${ }^{7}$ http://www.wwdsi.com/saint/ (visitado em 04/02/2002)

${ }^{8}$ http://naughty.monkey.org/ dugsong/dsniff/ (visitado em (visitado em 04/02/2002))

${ }^{9}$ http://www.fish.com/satan/ (visitado em 04/02/2002)

${ }^{10}$ http://www.chkrootkit.org/ (visitado em 04/02/2002)
} 
- Se forem usados regularmente, podem apontar mudanças de maneira confiável no estado de segurança de um sistema, alertando o time de segurança à cerca de problemas que demandam correção.

- Oferecem uma maneira para implementar checagem dupla quanto a mudanças realizadas no sistema por administradores ou gerentes de segurança, assegurando que ao resolver um determinado problema, outros problemas não serão causados.

\section{Desvantagens:}

- Analisadores host-based são fortemente ligados a sistemas operacionais específicos e aplicações, sendo assim mais trabalhosos para construir, manter e gerenciar.

- Analisadores network-based são independentes de plataforma mas menos precisos e sujeitos a falsos alarmes.

- Algumas verificações network-based, especialmente aquelas relacionadas a ataques de comprometimento de recurso, podem causar um crash nos sistemas que estão sendo testados.

- Quando estiver desempenhando a avaliação de um sistema onde exista um SDI, este pode bloquear acessos futuros. Outro agravante refere-se aos testes freqüentes em alguns SDIs baseados em anomalia. A quantidade elevada de testes pode 'treiná-los' de forma a ignorarem ataques reais.

- Organizações que se utilizem destas políticas de análise devem assegurar que seus testes permaneçam limitados aos sistemas dentro de seus limites de controle, gerencial e político. Medidas para garantir a privacidade devem ser consideradas, especialmente quando os dados do cliente ou empregado estão incluídos nas fontes de informação.

Verificadores de integridade de arquivo- Essas ferramentas utilizam um sumário de mensagens (message digest) ou outro método de checksum cifrado para arquivos e objetos críticos do sistema, comparando-os a valores de referência, e apontando as diferenças.

O uso de checksums cifrados é importante pois freqüentemente atacantes alteram arquivos de sistema, em um de três estágios do ataque. Primeiro, alteram arquivos de sistema como objetivo do ataque (na colocação de um cavalo de tróia por exemplo), buscando de viabilizar pontos de entrada no sistema (backdoors), através dos quais possam ganhar acesso novamente em um momento posterior. Finalmente, tentam de cobrir suas 'pegadas', de tal forma que os proprietários do sistema não estejam cientes do ataque.

Vantagens: 
- Verificadores de integridade podem ser úteis no processo de atualização (aplicação de patches) ou outra mudança desejável nos binários do sistema.

- Constitui uma ferramenta valorosa àqueles conduzindo uma análise forense de sistemas que tenham sido atacados, pois habilitam um diagnóstico rápido e confiável da 'impressão digital' de um ataque. Isto permite que gerentes de sistema otimizem a restauração do serviço após a ocorrência de incidentes.

\section{Desvantagem:}

- Se uma política de manutenção não for definida para as assinaturas geradas pela ferramenta de verificação de integridade, sua utilização pode mascarar a presença do invasor no sistema e, por conseguinte, gerar uma falsa sensação de segurança ao usuário.

O produto freeware Tripwire ${ }^{11}$ é provavelmente o exemplo mais conhecido de verificador de integridade de arquivo.

Honey pots e Padded cells - São ferramentas recentes e ainda não amplamente difundidas. A grosso modo, o objetivo por trás do uso de tais ferramentas é criar um ambiente simulado onde a atividade intrusiva possa ser estudada sem o conhecimento do atacante. A seguir, estas ferramentas serão discutidas em detalhes.

Honey pots são sistemas de despistamento projetados para iludir um atacante potencial conduzindo-o para fora de sistemas críticos. Possuem o seguinte propósito:

- Iludir um atacante de forma que este não acesse sistemas críticos;

- Coletar informações sobre a atividade do atacante;

- Encorajar o atacante a ficar no sistema tempo suficiente para que os administradores possam formular uma resposta adequada.

Estes sistemas são preenchidos com informação falsa, projetada para parecer valiosa, mas a qual um usuário legítimo do sistema não teria acesso. Assim, qualquer acesso aohoney pot é suspeito. O sistema é equipado com sensores e monitores de eventos (event loggers) que detectam estes acessos e coletam informações sobre as atividades do atacante.

Padded cells utilizam uma abordagem diferente. Ao invés de tentar atrair atacantes com dados tentadores, um padded cell opera juntamente com um SDI tradicional. Quando o SDI identifica atacantes potenciais, ele os transfere de forma transparente a um padded cell host. Uma vez que o invasor esteja na padded cell, eles são contidos em um ambiente

\footnotetext{
${ }^{11}$ http://www.tripwiresecurity.com/ (visitado em 04/02/2002).
} 
simulado onde não podem causar danos. Como nos honey pots, este ambiente simulado pode ser preenchido com dados interessantes, projetados para convencer o atacante de que o ataque está se desenvolvendo como planejado. Como noshoney pots, padded cells são bem equipados e oferecem oportunidades únicas para monitorar ações ilítitas. Pesquisadores de SDI vem utilizando mecanismos de padded cells e honey pots desde 1980, mas até recentemente essas técnicas não eram utilizadas com freqüência ${ }^{12}$. É importante buscar auxílio legal antes de decidir-se pela utilização de um destes sistemas no ambiente operacional da organização.

\section{Vantagens:}

- Atacantes podem ser desviados para alvos que não podem danificar.

- Administradores conseguem um tempo adicional para decidir como responder ao ataque.

- As ações do invasor podem ser facilmente e mais extensivamente monitoradas, com os resultados usados para refinar modelos de ameaças e melhorar a proteção dos sistemas.

- Honey pots podem ser efetivos na identificação de pessoal interno que esteja bisbilhotando a rede.

\section{Desvantagens:}

- As implicações legais para o uso de tais mecanismos não são bem definidas (Bace and Mell, 2001).

- Honey pots e padded cells não foram comprovados como tecnologias de segurança aplicáveis (uma comprovação formal).

- Um atacante experiente, uma vez desviado para um sistema simulado, pode ficar furioso (caso descubra) e lançar um ataque mais hostil contra os sistemas de uma organização.

- Um alto grau de habilidade é exigido do administrador ou gerente de segurança que deseje aplicar estas técnicas de forma efetiva e sem oferecer riscos a organização.

\subsection{Características desejáveis de um SDI}

Até o momento, foram apresentados os modelos existentes de SDIs, bem como as vantagens e desvantagens relativas a utilização de cada um deles. Além disso, foram descritas ferramentas cuja finalidade é auxiliar o funcionamento de SDIs, de forma a deixar seu escopo

\footnotetext{
${ }^{12}$ Para uma discussão mais aprofundada no assunto referencie http://rr.sans.org/intrusion/honeypots.php (visitado em 04/02/2002)
} 
de aplicação mais abrangente, além de evitar falhas de segurança inerentes a arquitetura. Esse material é imprescindível para os desenvolvedores de SDIs.

Vale a pena citar que nada foi mencionado com relação a aplicação de SDIs em ambientes computacionais distintos, e com diferenças tecnológicas inerentes a cada um deles. Como deve ser regulado o funcionamento e configuração do SDI com relação a topologia do ambiente sob monitoramento? O que realmente se espera de um sistema desta natureza e por que sua utilidade encontra-se tão em evidência atualmente? Essas são algumas perguntas que deverão ser respondidas ao longo desta seção.

Esta seção tem o objetivo de apresentar as características desejáveis e únicas fornecidas pelos SDIs. Para este propósito, não existe a necessidade de classificação do SDI segundo o modelo proposto anteriormente. As características apresentadas são genéricas o suficiente para serem aplicadas a qualquer SDI existente.

As seguintes características foram definidas por (Crosbie and Spafford, 1995) como desejáveis para um SDI:

- Deve funcionar continuamente com supervisão humana mínima;

- Deve ser tolerante a falhas podendo recuperar-se de panes de sistema (crashes), acidentais ou causadas por atividade maliciosa. Ao iniciar, o SDI deve ter a capacidade de recuperar seu estado anterior e recomeçar sua operação normalmente;

- Deve resistir a subversão. O SDI deve ser capaz de auto-monitoramento e detectar se foi modificado por um atacante;

- Deve impor uma sobrecarga mínima, para evitar interferir com a operação normal dos sistemas sob vigilância;

- Deve ser configurável para implementar precisamente as políticas de segurança dos sistemas que estão sendo monitorados;

- Deve ser adaptável às mudanças no comportamento do sistema e do usuário ao longo do tempo. Por exemplo, aplicações novas sendo instaladas, mudanças no perfil do usuário ou novos recursos disponíveis podem causar alterações nos padrões de utilização do sistema. À medida que aumentam o número de sistemas a serem monitorados e as possibilidades de ocorrência de ataques, as seguintes características tornam-se imprescindíveis:

- O sistema deve ser escalável, possibilitando o monitoramento de um grande número de hosts, enquanto fornece resultados de maneira precisa e oportuna. 
- Deve fornecer a degradação gradual do serviço. Se alguns componentes do SDI pararem de funcionar por algum motivo, os demais serviços devem sofrer um impacto mínimo.

- Deve possibilitar uma reconfiguração dinâmica, permitindo que o administrador efetue mudanças em sua configuração sem a necessidade de reiniciar o SDI inteiro.

Tendo estabelecido as características que regem o bom funcionamento de um SDI, ainda existe a necessidade de delinear algumas diferenças topológicas no sistema. Os SDIs, além da classificação apresentada no modelo proposto por (Bace and Mell, 2001), podem ser classificados como centralizados ou distribuídos (Zamboni and Spafford, 2000).

Para o escopo do trabalho proposto a diferenciação entre estes dois modelos arquiteturais é importante tendo em vista que o objetivo final do trabalho é, em última análise, proporcionar as ferramentas necessárias para a distribuição do SDI desenvolvido no ICMC (Cansian, 1997). As diferenças entre os modelos topológicos supracitados serão apresentadas a seguir.

\subsection{Detecção de intrusão centralizada e distribuída}

Outra forma de classificação para os SDIs refere-se a maneira pela qual seus componentes de sistema são distribuídos. Essa diferença na arquitetura é crítica ditando o funcionamento do sistema como um todo. As tabelas 3.1 e 3.2 tem por objetivo elucidar as diferenças principais entre esses dois modelos e, validar as discussões futuras referentes as alterações realizadas no SDI do ICMC (Cansian, 1997).

\subsubsection{Comparação entre SDIs centralizados e distribuídos}

Em um SDI centralizado a análise dos dados é realizada em um número fixo de lugares, independente da quantidade de hosts sendo monitorados. A posição dos componentes de levantamento de dados é irrelevante, sendo consideradas apenas a posição dos componentes de análise. Alguns SDIs que são classificados como centralizados são: IDES (Denning et al., 1987), (Denning and Neumann, 1985), (Lunt et al., 1988), (Lunt et al., 1992), IDIOT (Crosbie et al., 1996),(Kumar, 1995), NADIR (Hochberg et al., 1993) e NSM (Heberlein et al., 1990).

Em um SDI distribuído a análise dos dados é realizada em um número de posições proporcional ao número de hosts que estão sendo monitorados. Novamente, são consideradas somente as posições e número de componentes da análise de dados. Alguns SDIs que podem ser classificados como distribuídos são: DIDS (Snapp et al., 1991), (Snapp et al., 1992), GrIDS (Cheung et al., 1999), (Staniford-Chen et al., 1996), EMERALD (Porras and Neumann, 1997) e o AAFID (Balasubramaniyan et al., 1998). 
As tabelas 3.1 e 3.2 descreve as vantagens e desvantagens referente a SDIs centralizados e distribuídos, com relação as características desejáveis descritas na seção 3.3. Percebe-se que SDIs centralizados possuem algumas vantagens sobre SDIs distribuídos, mas isso não limita de forma alguma sua aplicação. Em contrapartida, os SDIs centralizados possuem algumas particularidades como, por exemplo, a falta de escalabilidade e a dificuldade em proporcionar uma degradação gradual do serviço; fatores que prejudicam seu funcionamento a longo prazo.

Com isso, o campo de detecção de intrusão tem se voltado nos últimos anos anos ao desenvolvimento e construção de SDIs distribuídos (por exemplo, (Balasubramaniyan et al., 1998), (Bradley et al., 1998), (Hofmeyr, 1999), (Porras and Neumann, 1997), (Staniford-Chen et al., 1996)). Neste contexto, será discutida uma abordagem para a construção de um SDI distribuído usando a tecnologia de agentes autônomos como base. Pretende-se erradicar as falhas particulares a SDIs centralizados (mencionado anteriormente) além de conferir ao SDI do ICMC uma maior modularidade e fácil movimentação de alguns de seus componentes ao longo da rede.

\subsection{Sumário}

A pesquisa em deteç̧ão de intrusão encontra-se ainda em sua juventude, tendo sido desenvolvida por aproximadamente 20 anos. Os SDIs existentes, em sua grande maioria, não tem alcançado um bom desempenho na presença de fontes de evidências sujeitas a falhas e frente a invasores mais experientes, que podem encobrir suas ações através de uma grande variedade de métodos sofisticados.

Neste capítulo foram apresentados fortes argumentos que atribuem estas falhas a estrutura rígida e pouco flexível assumida pela maioria dos SDIs (abordagem centralizada). Também foi mostrado que ambientes distintos possuem demandas diferentes, ou seja, é necessário que o SDI possua caráter deliberativo reagindo de forma diferenciada e apropriada de acordo com o contexto no qual estiver inserido (atendendo da melhor forma possível às premissas apresentadas na seção 3.4).

O próximo capítulo irá introduzir e aprofundar os conceitos relativos a tecnologia escolhida para o desenvolvimento do SDI modelado pelo grupo de segurança: a tecnologia de agentes autônomos. Para tanto, será fornecida uma breve introdução as entidades conhecidas como agentes e o contexto no qual estão inseridos para o desenvolvimento do sistema. Esse capítulo será de suma importância para a descrição do trabalho relativo a adaptação da sonda de captura estática para o ambiente de redes chaveadas. 


\begin{tabular}{|c|c|c|}
\hline Característica & Centralizado & Distribuído \\
\hline Execução contínua & $\begin{array}{l}\text { Um número relativamente } \\
\text { pequeno de componentes } \\
\text { precisa ser mantido execu- } \\
\text { tando. }\end{array}$ & $\begin{array}{l}\text { Mais difícil pois um grande } \\
\text { número de componentes } \\
\text { precisa ser mantido execu- } \\
\text { tando. }\end{array}$ \\
\hline Tolerante a falhas & $\begin{array}{l}\text { O estado do SDI é ar- } \\
\text { mazenado em uma entidade } \\
\text { central, tornando simples } \\
\text { sua recuperação após uma } \\
\text { falha de sistema. }\end{array}$ & 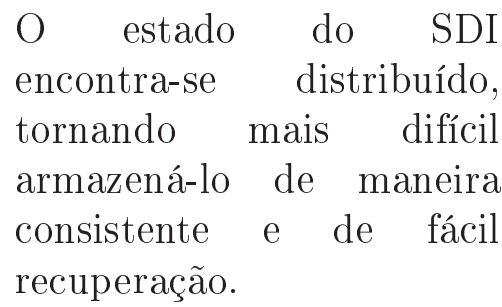 \\
\hline Resistência a subversão & $\begin{array}{l}\text { Um número menor de com- } \\
\text { ponentes precisa ser mon- } \\
\text { itorado. Entretanto, estes } \\
\text { componentes são maiores } \\
\text { e mais complexos, tor- } \\
\text { nando seu monitoramento e } \\
\text { manutenção mais difícil. }\end{array}$ & $\begin{array}{l}\text { Um número maior de com- } \\
\text { ponentes precisa ser moni- } \\
\text { torado. Entretanto, devido } \\
\text { a sua quantidade, podem } \\
\text { realizar referência cruzada } \\
\text { (cross-check) entre si. Eles } \\
\text { também são menores e } \\
\text { menos complexos. }\end{array}$ \\
\hline Sobrecarga mínima & $\begin{array}{l}\text { Provoca pouca ou nenhuma } \\
\text { sobrecarga ao sistema, ex- } \\
\text { ceto aqueles onde os com- } \\
\text { ponentes de análise es- } \\
\text { tão executando, onde uma } \\
\text { grande carga é imposta. } \\
\text { Pode haver a necessidade } \\
\text { de utilização de hosts dedi- } \\
\text { cados. }\end{array}$ & $\begin{array}{l}\text { Provoca pouca sobrecarga } \\
\text { nos sistemas, pois os com- } \\
\text { ponentes executando são } \\
\text { menores, entretanto, essa } \\
\text { carga extra é imposta na } \\
\text { maioria dos sistemas sob } \\
\text { monitoramento. }\end{array}$ \\
\hline Configuração & $\begin{array}{l}\text { Mais fácil de } \\
\text { globalmente, } \\
\text { ao menor número devido } \\
\text { componentes. } \\
\text { ser difícil o ajuste de } \\
\text { características específicas } \\
\text { dos diferentes hosts sob } \\
\text { monitoramento. }\end{array}$ & $\begin{array}{l}\text { Cada componente pode es- } \\
\text { tar localizado no conjunto } \\
\text { de hosts que está sendo } \\
\text { monitorado, tornando o } \\
\text { ajuste de tarefas específicas } \\
\text { mais simples. }\end{array}$ \\
\hline Capacidade de adaptação & $\begin{array}{l}\text { Através da concentração de } \\
\text { informação em menos lu- } \\
\text { gares, é mais fácil detec- } \\
\text { tar mudanças no comporta- } \\
\text { mento global. O comporta- } \\
\text { mento local é mais difícil de } \\
\text { ser analisado. }\end{array}$ & $\begin{array}{l}\text { Os dados são distribuídos, } \\
\text { o que pode tornar o ajuste } \\
\text { de mudanças globais de } \\
\text { comportamento mais difí- } \\
\text { cil. Mudanças locais são } \\
\text { mais facilmente detectadas. }\end{array}$ \\
\hline
\end{tabular}

Tabela 3.1: Comparação entre SDIs centralizados e distribuídos com respeito as características desejáveis descritas na seção 3.3. 


\begin{tabular}{|c|c|c|}
\hline Característica & Centralizado & Distribuído \\
\hline $\begin{array}{l}\text { Degradação gradual do } \\
\text { serviço }\end{array}$ & $\begin{array}{l}\text { Caso um dos componentes } \\
\text { de análise pare de fun- } \\
\text { cionar, é muito provável } \\
\text { que o SDI como um todo } \\
\text { pare de funcionar também. } \\
\text { Cada componente constitui } \\
\text { um ponto único de falha. }\end{array}$ & $\begin{array}{l}\text { Se um componente de } \\
\text { análise parar de funcionar, } \\
\text { parte da rede pode parar } \\
\text { de ser monitorada, mas } \\
\text { o restante do SDI pode } \\
\text { continuar suas funções. }\end{array}$ \\
\hline Reconfiguração dinâmica & $\begin{array}{l}\text { Um pequeno número de } \\
\text { componentes analisa todos } \\
\text { os dados. A reconfiguração } \\
\text { deles requer que o SDI seja } \\
\text { reinicializado. }\end{array}$ & $\begin{array}{l}\text { Componentes individuais } \\
\text { podem ser reconfigurados } \\
\text { e reiniciados sem afetar o } \\
\text { restante do SDI. }\end{array}$ \\
\hline Modularidade (scalable) & $\begin{array}{l}\text { O tamanho dos SDIs é } \\
\text { limitado pelo número de } \\
\text { componentes removidos. À } \\
\text { medida que o número de } \\
\text { hosts sob monitoramento } \\
\text { aumenta, os componentes } \\
\text { de análise irão precisar de } \\
\text { mais recursos de proces- } \\
\text { samento e armazenamento } \\
\text { para suportar a carga. }\end{array}$ & $\begin{array}{l}\text { Um SDI distribuído pode } \\
\text { se adaptar a um número } \\
\text { maior de hosts através } \\
\text { da adição de componentes } \\
\text { quando necessário. O grau } \\
\text { de escalabilidade pode ser } \\
\text { limitado pela necessidade } \\
\text { de comunicação entre os } \\
\text { componentes, e pela ex- } \\
\text { istência de componentes de } \\
\text { coordenação centrais. }\end{array}$ \\
\hline
\end{tabular}

Tabela 3.2: Comparação entre SDIs centralizados e distribuídos com respeito as características desejáveis descritas na seção 3.3 (continuação). 
No presente trabalho, o paradigma de detecção de intrusão é abordado seguindo o modelo distribuído apresentado no capítulo 3. A arquitetura distribuída utiliza unidades pequenas e independentes, conhecidas como agentes, para detectar o comportamento suspeito. Esse esquema possui vantagens quando comparado a arquiteturas monolíticas (como ficou claro na seção 3.4) em termos de modularidade (scalable), eficiência, tolerância a falhas e facilidade de configuração. A proposta base refere-se ao estudo realizado por (Bernardes, 1999) para a construção de um sistema estruturado usando agentes móveis.

O objetivo desse trabalho é estudar as tecnologias necessárias para expandir a área de influência do agente de captura estático, situado na primeira camada do modelo (explicado em maiores detalhes no capítulo 5) e sua relação com os demais agentes dessa camada. Serão feitas considerações de suma importância referentes a aplicação do SDI em redes chaveadas, atividade de difícil implementação no sistema original (Cansian, 1997).

\subsection{Breve introdução a tecnologia de agentes}

Um agente de software segundo (Bradshaw, 1997) apud (Zamboni and Spafford, 2000) pode ser definido como:

“... Uma entidade de software que funciona de maneira contínua e autônoma em um ambiente particular... com a habilidade de conduzir atividades de forma flexível e inteligente, sensível a mudanças no ambiente... Em condições favoráveis, um agente que trabalha continuamente... estaria capacitado a aprender a partir de suas experiências. Além 
disso, é esperado que um agente que habita um determinado ambiente juntamente com outros agentes e processos, seja capaz de se comunicar com eles, e, talvez, se deslocar de um local a outro ao fazer isso."

No presente contexto, um agente autônomo (de agora em diante agente) pode ser definido como um agente de software que execute uma determinada função de monitoração de segurança em um host.

Os agentes são referenciados como autônomos porque são entidades auto-suficientes (independently running); ou seja, sua execução é programada somente pelo sistema operacional, e não por um outro processo. Os agentes podem ou não necessitar dos dados produzidos por outros agentes para executar seu trabalho. Além disso, os agentes podem receber comandos de controle de alto nível de outras entidades (como indicações para começar/encerrar a execução ou mudar alguns parâmetros operacionais). Nenhuma dessas características prejudica a definição de autonomia do agente.

\subsubsection{Utilizando agentes autônomos na construção de um SDI dis- tribuído}

Considerando o fato de que agentes são entidades auto-suficientes, eles podem ser adicionados, removidos e reconfigurados sem alterar outros componentes e sem a necessidade de reiniciar o SDI. Os agentes podem ser testados isoladamente antes de serem inseridos em um ambiente estruturado. Também podem pertencer a um grupo que desempenhe funções simples possuindo a capacidade de trocar informações de forma a derivar resultados mais complexos do que qualquer um deles seria capaz de obter sozinho.

O desempenho de um SDI construído usando agentes autônomos com relação às características desejáveis listadas na seção 3.4 pode ser ilustrado como mostrado em (Zamboni and Spafford, 2000):

- Execução contínua - Se um SDI é constituído por um certo número de agentes autônomos, alguns deles podem ser pegos on-line para manutenção ou por outras razões, enquanto outros permanecem executando, promovendo assim, uma funcionalidade de detecção de intrusão contínua.

- Tolerância a falhas - O armazenamento e recuperação de estados globais ainda é problemático, como descrito na seção 3.4 para SDIs distribuídos. Agentes autônomos, entretanto, estariam aptos a manutenção de estados locais e recuperação ao iniciar.

- Resistência a subversão - A capacidade de monitoramento próprio (self-monitoring) em agentes autônomos é um problema difícil, sendo tema de pesquisas atuais (Farmer 
et al., 1996) apud (Zamboni and Spafford, 2000). Uma possibilidade é aceitar agentes mediante verificação, realizando uma checagem periódica feita por outros agentes. Se um agente coleta informações de rede relacionadas ao host no qual está executando, o sistema fica mais suscetível a possibilidade de ataques de inserção e evasão (Ptacek and Newsham, 1998), que são uma forma de subversão, e ao qual SDIs network-based estão geralmente sujeitos.

- Sobrecarga mínima - Agentes bem projetados podem impor uma carga mínima ao sistema sob análise. Além disso, os agentes podem ser habilitados e desabilitados, tornando possível o uso de recursos somente para as tarefas necessárias em um determinado instante.

- Configuração - Um agente pode ser configurado (ou ainda implementado) especificamente para as necessidades do host onde irá executar. Agentes autônomos, desta forma, permitem habilidades de configuração de granulosidade fina.

- Capacidade de adaptação - Cada agente tem um conhecimento específico que o torna capaz de se adequar a mudanças no comportamento local. Possuindo uma visão em alto nível do estado do sistema, existe também a possibilidade de adaptação às mudanças no comportamento global. Uma forma de realizar isso seria através da adição ou remoção automática de agentes, para o monitoramento de eventos que são considerados relevantes em um certo período de tempo.

- Modularidade (scalable) - Os agentes são engendrados para os hosts que precisam ser monitorados. Assim, um SDI baseado em agentes pode ter sua complexidade incrementada através do desenvolvimento de novos agentes, à medida que esses se tornem necessários. Os mecanismos de comunicação podem constituir o gargalo entre os agentes e os componentes de coordenação central, caso existam. Outro problema a ser considerado refere-se às capacidades de processamento desses componentes. Ambos os problemas podem ser resolvidos através de esquemas propostos para a construção de SDIs (Hofmeyr, 1999), (White et al., 1996) sem a necessidade de uma entidade central de controle. Isso minimiza a quantidade desnecessária de comunicação entre componentes (Hofmeyr, 1999). Mesmo ao usar esquemas tradicionais de comunicação, os SDIs podem tornar-se modulares através da organização de agentes em uma estrutura hierárquica. Essa idéia foi proposta em (M. Crosbie, 1995) e também foi usada em (Staniford-Chen et al., 1996).

- Degradação gradual do serviço - Se um agente parar de funcionar por alguma razão, podem ocorrer os seguintes casos: 
- Se o agente produzir resultados por conta própria, somente os seus resultados serão perdidos. Todos os outros agentes irão continuar suas funções normalmente.

- Caso os dados produzidos pelo agente sejam necessários por outros agentes, aquele grupo de agentes pode ser prejudicado. Mesmo assim, as dependências de dados entre agentes são conhecidas de antemão, de tal forma que as conseqüências da falha podem ser previstas.

Em todo caso, existe o dano a pelo menos um grupo de agentes. Assim, se os agentes são organizados corretamente em grupos mutuamente independentes, a degradação do serviço provida pelo SDI será gradual e proporcional ao número de agentes que param de funcionar.

- Reconfiguração dinâmica - a habilidade para iniciar e encerrar agentes independentemente cria a possibilidade de reconfigurar o SDI sem a necessidade de reiniciá-lo. Se for preciso iniciar a coleta de um novo tipo de dado ou monitorar novos tipos de ataques, os agentes apropriados podem ser iniciados sem atrapalhar aqueles que já estão em funcionamento. De forma similar, agentes que não são mais necessários podem ser encerrados, e agentes que precisam ser reconfigurados podem receber os comandos apropriados sem a necessidade de reiniciar o SDI inteiro.

- Benefícios adicionais - Utilizar agentes como entidades de coleta e análise de dados também promove as seguintes vantagens adicionais:

- Já que um agente pode ser programado arbitrariamente, ele pode obter seus dados a partir de um registro de auditoria, através da sondagem do sistema onde está inserido, através da captura de pacotes da rede, ou a partir de qualquer outra fonte adequada. Assim, um SDI baseado em agentes pode cruzar as fronteiras tradicionais entre SDIs host-based e network-based.

- Como agentes podem ser encerrados e iniciados sem perturbar o resto dos componentes do SDI, eles podem ser atualizados à medida que mais funcionalidades são necessárias. Desde que sua interface externa permaneça compatível, outros componentes nem mesmo precisam saber que o agente foi atualizado.

- Se os agentes forem implementados como processos separados em um host, cada um pode ser desenvolvido na linguagem de programação mais apropriada para a tarefa que deve ser desempenhada. 


\subsubsection{Taxonomia dos Agentes}

Essa seção apresenta uma tentativa de classificar os tipos de agentes existentes, em diferentes classes, através da apresentação de uma taxonomia de agentes. Os conceitos aqui exibidos são baseados no trabalho desenvolvido por (Pereira Filho, 2001) em seu projeto de mestrado.

Em (Nwana, 1996) são apresentadas várias dimensões para a classificação dos agentes existentes. Primeiramente, os agentes podem ser classificados pela sua habilidade de se mover através da rede de computadores (mobilidade). Podem ser estáticos ou móveis. A segunda dimensão refere-se ao modo de funcionamento deliberativo ou reativo do agente. Um agente deliberativo possui um modelo de raciocínio simbólico interno, que permite o planejamento e negociação das tarefas com outros agentes, de modo a coordenar a execução. Agentes reativos, por outro lado, apresentam um comportamento do tipo estímulo/resposta: o agente responde ao estado atual do ambiente no qual está imerso, não possuindo o modelo de raciocínio simbólico. A terceira dimensão envolve a classificação relativa às diversas propriedades ideais e fundamentais que um agente deveria apresentar. Em (Nwana, 1996) é citada uma lista de três propriedades: autonomia, aprendizagem e cooperação. A quarta dimensão é relacionada com o papel assumido pelo agente na aplicação, por exemplo, agentes de informação para WWW. A quinta dimensão refere-se a categoria dos agentes híbridos, que combinam duas ou mais das outras dimensões citadas em um único agente.

Considerando o desenvolvimento de aplicações, os agentes podem aparecer em várias das dimensões descritas anteriormente. Em (Nwana, 1996) a combinação dessas várias dimensões é reduzida a uma lista arbitrária, genérica o bastante para cobrir a maioria dos tipos de agentes em investigação atualmente. São identificados sete tipos de agentes:

- Agentes colaboradores - Enfatizam a autonomia e a cooperação com outros agentes para executar tarefas para seus donos. Exemplos incluem agentes baseados no paradigma crenças-desejos-intenções sugerido por muitos autores da área de inteligência artificial distribuída;

- Agentes de interface - Enfatizam a autonomia e a aprendizagem. A metáfora chave que dá suporte a esses agentes refere-se ao exemplo do assistente pessoal que colabora com o usuário em um mesmo ambiente de trabalho. O objetivo principal é migrar da manipulação direta da interface. pelo usuário para a delegação de tarefas aos agentes de interface Isso facilitaria a utilização por usuários novatos, uma vez que muitas tarefas são muito complexas ou trabalhosas e exigem treinamento intensivo para sua execução correta;

\footnotetext{
${ }^{1} \mathrm{O}$ termo taxonomia refere-se ao estudo dos princípios gerais de classificação científica. Fonte: Merriam-Webster OnLine - Webster Dictionary, http://www.m-w.com/dictionary (visitado em 06/02/2002).
} 
- Agentes móveis - São processos capazes de "vagar" através de redes de comunicação, interagindo com máquinas, coletando informações e retornando após executar as funções atribuídas pelo usuário. Apesar de mobilidade não ser uma condição necessária ou suficiente para o conceito de agente, os agentes móveis apresentam uma série de vantagens sobre os similares estáticos, como por exemplo: redução dos custos de comunicação, independência considerando a limitação imposta pelo uso de recursos locais, coordenação mais fácil, computação assíncrona, ambiente de desenvolvimento natural para serviços de comércio eletrônico, arquitetura flexível para computação distribuída, além de fornecerem uma nova abordagem, atraente e distinta para o desenvolvimento e projeto de aplicações (Bernardes, 1999);

- Agentes de informação - Realizam funções de gerenciamento, manipulação e ordenação de informações oriundas de várias fontes distribuídas. A necessidade por agentes desse tipo específico advém da quantidade enorme de informações disponíveis e que precisam ser pesquisadas. Esses agentes utilizam-se de outras tecnologias, tais como índices de busca on-line (Altavista, InfoSeek, Lycos, etc), para compilar a informação sobre algum assunto requisitado pelo usuário e retornar o resultado esperado;

- Agentes reativos - Representam uma categoria especial de agentes que não possuem nenhuma forma de representação simbólica interna, agindo de acordo com o estado atual do ambiente em que estão imersos através de estímulos e respostas. Esses agentes normalmente são simples e se comunicam de maneira básica, proporcionando o aparecimento de padrões de comportamento complexos, a partir da interação entre os diversos agentes. São compostos por módulos autônomos que desempenham tarefas bem específicas e lidam com representações próximas do nível físico (dados de sensores) ao invés de representações simbólicas de alto nível. Algumas vantagens seriam robustez, flexibilidade e adaptação frente as técnicas clássicas utilizadas na implementação de agentes inteligentes;

- Agentes híbridos - Esses agentes são o resultado da utilização integrada de várias filosofias existentes. Por exemplo, um agente que implementa tanto o comportamento reativo, quanto o deliberativo, poderia apresentar respostas mais rápidas a mudanças no seu ambiente aplicando o comportamento reativo, enquanto outros problemas orientados a metas e que não exijam tal agilidade seriam tratados pelo comportamento deliberativo;

- Agentes inteligentes - São agentes capazes de apresentar todas as características citadas relativas a autonomia, aprendizagem e cooperação. Em realidade, representam apenas o desejo atual dos pesquisadores. 
É possível encontrar sistemas que utilizem dois ou mais tipos de agentes. Em (Nwana, 1996), essas aplicações são referenciadas como sistemas de agentes heterogêneos.

\subsection{Agentes Móveis}

Agentes móveis podem ser definidos como:

"Agentes que possuem a capacidade de se mover através da rede. Devem estar aptos a executar operações em qualquer máquina preparada para recebê-los no âmbito da rede, independente da plataforma utilizada. Esse fato motiva a aplicação da linguagem Java como ferramenta para a implementação dos agentes móveis, permitindo sua utilização em redes heterogêneas" (adaptado a partir de (Pereira Filho, 2001)).

Em modelos baseados nesse princípio, um agente é enviado pelo usuário, que delega a ele a responsabilidade pelo cumprimento da tarefa desejada. Nesses ambientes, o agente irá migrar para o servidor, interagindo com ele localmente, retornando em seguida os resultados obtidos (Oyamada and Ito, 1998) apud (Pereira Filho, 2001). Um agente pode executar as tarefas a ele designadas mesmo com o host de origem desativado. Quando uma tarefa demanda um processamento intenso, o agente pode ser executado em outra máquina mais robusta, tornando-se uma ferramenta interessante para balanceamento de carga.

Os agentes móveis são constituídos de código, estado e atributos. O código de um agente móvel é o programa que define o seu comportamento. Esse deve necessariamente, ser escrito em uma linguagem independente de plataforma (código binário portável), permitindo assim a mobilidade do agente. O estado do agente é utilizado para que ele possa retomar suas atividades a partir do ponto onde foi interrompido, após se mover de um servidor a outro. O estado armazena o ponto de execução e as variáveis necessárias para a realização das tarefas. Finalmente, os atributos são utilizados para descrever o agente aos seus servidores; incluindo um identificador único, um endereço para onde serão enviados resultados intermediários, mensagens de erro ou relatórios relativos ao comportamento malicioso, o tempo e a história do agente, além de impor limitações quanto a mobilidade, limites de domínios nos quais pode trafegar e limites de tempo de ação sob a forma de um prazo de expiração.

Os ambientes que abrigam os agentes, denominados de servidores, devem oferecer todo o suporte à realização das tarefas desejadas. Para que isso ocorra, os agentes devem ser capazes de interagir com os servidores, comunicar-se entre si e se mover através da rede. Outra função de extrema importância dos sistemas de agentes é garantir a segurança, tanto dos servidores quanto dos agentes neles hospedados. 
A comunicação entre os agentes e servidores pode ser síncrona quando as partes envolvidas se encontram no instante anterior ao início da transferência de dados propriamente dita. Esse tipo de comunicação é adequado em situações onde a transferência de dados necessita de confirmação imediata. Caso contrário, a comunicação é dita assíncrona (Oyamada and Ito, 1998) apud (Pereira Filho, 2001).

Em termos de organização, a arquitetura de um sistema de agentes (ou objetos) móveis é composta por quatro componentes:

- Host - Um computador e sistema operacional constituem o ambiente computacional $(\mathrm{AC})$;

- O sistema de execução (run-time system), sistemas de agentes (ou objetos) móveis;

- O conjunto de computações sendo executadas em um AC, e;

- A rede ou subsistema de comunicação que interliga os vários ACs executando em hosts diferentes (Vitek and Tschudin, 1997).

Os componentes da arquitetura interagem uns com outros para implementar o comportamento dos agentes e, dependendo das permissões e restrições associadas a essas interações podem ocorrer problemas de segurança (Bernardes, 1999).

\subsubsection{O modelo de comunicação dos aglets}

Na seção anterior, o modelo de comunicação dos agentes móveis foi apresentado de forma genérica. Para o escopo deste trabalho, o ambiente de desenvolvimento utilizado foi o ASDK (Aglets Software Development $K i t^{2}$ ) e esta seção tem por objetivo detalhar seu modelo de comunicação. Os agentes criados nesse ambiente denominam-se aglets e comunicam-se via passagem de mensagens.

O mecanismo de passagem de mensagem permite que os aglets criem e troquem mensagens de forma flexível. Segundo esse padrão, o modelo não assume a manipulação de mensagens concorrentes ${ }^{3}$. Isto significa que todas as mensagens são manipuladas isoladamente (uma por vez).

\subsubsection{A camada de comunicação}

A camada runtime dos aglets não transfere agentes diretamente pela rede. Ao invés disso, utiliza uma camada de comunicação. A grande vantagem desta arquitetura é tornar

\footnotetext{
${ }^{2}$ Escolha justificada através do trabalho desenvolvido em (Pereira Filho, 2001).

${ }^{3}$ Para maiores detalhes vide (Lange and Oshima, 1998), capítulo 6.
} 
a camada runtime independente do mecanismo de transporte. A camada de comunicação define e implementa um conjunto de métodos genéricos que suporta um esquema de mensagens inter-agentes e transporte do estado dos agentes e bytecode associado, independente do sistema de agentes.

\subsubsection{API de comunicação}

A API de comunicação usada pelo ambiente runtime dos aglets é derivada do padrão MASIF (Mobile Agent System Interoperability Facility ${ }^{4}$ ) da OMG (Object Management Group ${ }^{5}$ ), permitindo a operação conjunta entre vários sistemas de agentes. Essa API abstrai a camada de comunicação através da definição de interfaces e fornecimento de representações simples de dados. Embora não seja uma verdadeira interface CORBA (Common Object Request Broker Architecture ${ }^{6}$ ), é fácil implementar um wrapper que verdadeiramente utilize objetos MASIF.

Essa abordagem foi escolhida considerando as seguintes desvantagens decorrentes da dependência de um protocolo ou mecanismo de transporte específico:

- Exigir que um agente móvel use um protocolo específico não seria tecnicamente apropriado, a menos que o protocolo fosse invasivo. Assim, o mecanismo de comunicação da rede torna-se transparente.

- Alguns ambientes Java, como o PersonalJava, não suportam RMI (Remote Method Invocation) nem CORBA em suas APIs. Assim sendo, seria desejável que o ambiente runtime escolhesse os mecanismos de comunicação seguindo os padrões do ambiente escolhido.

Dois objetos CORBA são definidos no MASIF:MAFAgentSystem e MAFFinder. O objeto MAFAgentSystem define métodos para criação, transferência e gerenciamento de agentes. Para enviar um agente, o emissor primeiro localiza o objeto do sistema de agentes remoto por meio de serviços CORBA normais e pela chamada receive_agent() nesse objeto remoto, com argumentos que contém o código e o estado do agente. O objetoMAFFinder define um serviço de nomes para localizar agentes em transição (roaming).

\subsubsection{Protocolo de transferência de agentes}

O protocolo de transferência de agentes Agent Transfer Protocol (ATP) é um protocolo de nível de aplicação simples, modelado segundo o HTTP. O ATP é projetado para transmitir

\footnotetext{
${ }^{4}$ http://www.hpl.hp.com/personal/Dejan_Milojicic/ma4.pdf (visitado em 23/07/2002).

${ }^{5}$ http://www.omg.org/(visitado em 23/07/2002).

${ }^{6} \mathrm{http}: / /$ www.corba.org/ (visitado em 23/07/2002.
} 
um agente independente do sistema de agentes. A linha de solicitação especifica o método de requisição, e os campos de cabeçalho contém os parâmetros do pedido. O ATP define os seguintes métodos para a requisição:

- Dispatch: Solicita a um sistema de agentes destino a reconstrução de um agente a partir do conteúdo de um pedido e o início de sua execução. Se o pedido for bem sucedido, o emissor deve finalizar o agente e liberar quaisquer recursos consumidos por ele.

- Retract: Solicita que um sistema de agentes destino envie o agente especificado de volta ao emissor. O receptor é responsável por reconstruir e reiniciar o agente. Se o agente for transferido com sucesso, o receptor deve terminar o agente e liberar quaisquer recursos consumidos por ele.

- Fetch: É similar ao método GET no HTTP. Solicita que o receptor recupere e envie qualquer informação identificada.

- Message: É usado para passar a mensagem para o agente identificado por intermédio de um agentID e retorna um valor de resposta. Embora o protocolo adote a forma solicitação/resposta ele não define quaisquer regras para a comunicação entre agentes.

Normalmente, um servidor ATP irá tentar fazer uma conexão direta ahosts na rede. Entretanto, muitas redes são protegidas por umfirewall que previnem a abertura de conexões diretas via socket a nós externos. Assim sendo, umaglet não pode ser enviado ou recuperado de forma direta através de um firewall. Para solucionar esse problema, o ATP também suporta uma técnica chamada HTTP tunneling (figura). Esta técnica permite que uma solicitação ATP seja enviada para fora do firewall como um HTTP POST request e recuperada posteriormente como uma resposta HTTP. Além disso, o servidor ATP pode ser configurado para aceitar pedidos ATP HTTP-wrapped com o conteúdo type application/x-atp. Se um servidor ATP receber um pedido HTTP-wrapped, ele irá responder com uma resposta HTTP da mesma forma.

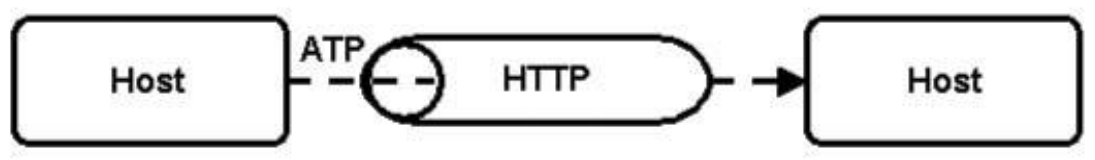

Figura 4.1: HTTP tunneling do ATP.

Como o firewall permite apenas conexões one-way para o meio exterior, um aglet enviado para fora do firewall não pode buscar uma classe dentro do escopo protegido pelo frewall. Certifique-se de que todas as classes estão armazenadas no fluxo de dados e são transferidas ao destino através de referências àquelas classes dentro do objeto, ou coloque-as 
no arquivo jar. Isso ocorre pois é impossível para um aglet retornar ao interior protegido pelo firewall. Para que um aglet retorne a rede protegida é preciso utilizar o recurso de recuperação (retraction) para trazer o aglet de um local remoto.

\subsection{Sumário}

Foram apresentadas as vantagens decorrentes da utilização de um SDI construído com base no modelo de arquitetura distribuído em detrimento de um sistema centralizado. A tecnologia de agentes foi considerada a mais adequada e, por conseguinte, escolhida para a implementação do sistema (com base em estudos anteriores realizados pelo grupo de segurança). Nesse contexto, agentes autônomos foram definidos como entidades desoftware que executam uma determinada função de monitoração de segurança em umhost. A flexibilidade proporcionada por este modelo prevê a inclusão e remoção de agentes dinamicamente, sem a necessidade de interromper o sistema para a realização de modificações/atualizações.

Foi realizada uma análise comparativa do modelo escolhido, apresentando suas principais características frente a um sistema centralizado equivalente. Para isso, uma série de fatores ilustrados em (Zamboni and Spafford, 2000) (execução contínua, tolerância a falhas, resistência a subversão, sobrecarga mínima, configuração, capacidade de adaptação, modularidade, degradação gradual do serviço, reconfiguração dinâmica) foram referenciados.

Além disso, foi descrita uma proposta de taxonomia para a classificação dos tipos de agentes existentes (Nwana, 1996) em diferentes classes. Dentre os conceitos exibidos, a descrição fornecida para agentes móveis é de suma importância para o desenvolvimento do trabalho. A característica destacada é a capacidade de mobilidade no âmbito da rede, independente da plataforma utilizada.

Para complementar a discussão de agentes móveis relevante para o presente trabalho, foi inserida a descrição do protocolo de comunicação utilizado pelosaglets. Essa implementação de agentes móveis será discutida em maiores detalhes no capítulo referente a arquitetura do sistema.

O próximo capítulo apresenta a arquitetura do sistema proposto, baseada em agentes móveis. O modelo utilizado para o sistema foi inspirado nos cenários apresentados por (Bernardes, 1999) e, o ambiente de agentes foi escolhido com base no trabalho desenvolvido por (Pereira Filho, 2001). 


\section{Arquitetura do sistema: original e novas inclusões}

O objetivo principal desse capítulo é apresentar o modelo do sistema proposto em (Bernardes, 1999) em sua forma original e mostrar as modificações realizadas no decorrer do presente trabalho. As alterações propostas concentram-se na camada de vigilância do modelo; visando principalmente as funcionalidades desenvolvidas para o agente de captura de pacotes (maiores detalhes na seção 5.1).

\subsection{Estrutura original do modelo}

Os resultados obtidos no trabalho de mestrado de Mauro César Bernardes (Bernardes, 1999) foram usados como fundamento principal para o desenvolvimento do presente trabalho. Bernardes fornece a descrição de uma arquitetura modular baseada em agentes móveis para aplicação em sistemas detectores de intrusão (SDIs). Essa arquitetura representa a ferramenta principal para o desenvolvimento da solução desejada: um sistema de captura móvel e distribuído aplicável a redes chaveadas.

Segundo o modelo proposto em (Bernardes, 1999), o SDI é composto por um conjunto de pequenos processos (agentes) que podem agir de forma independente. São projetados para se moverem pelo ambiente no qual estão inseridos, observando o comportamento do sistema computacional alvo. Os agentes cooperam entre si via passagem de mensagens, notificando quando uma ação é considerada suspeita, podendo executar ações reativas. 
Uma vez que os agentes são independentes, eles podem ser adicionados e removidos do sistema dinamicamente, dispensando a necessidade de um processo de adaptação penoso de todo o sistema ou, a interrupção de sua atividade. Assim, a qualquer sintoma de uma nova forma de ataque, agentes especializados podem ser desenvolvidos, acoplados ao sistema e configurados para atender uma política de segurança específica.

O principal conceito relacionado ao sistema é a simplicidade. Cada agente é uma entidade única que irá desempenhar uma atividade específica e cooperar com outros agentes de forma eficiente e flexível. Quando uma atividade for considerada suspeita por um agente, ele irá informar ao sistema sua suspeita de uma possível intrusão. Nesse momento, será acionado um agente (ou um conjunto de agentes) com um maior grau de especialização naquele tipo de suspeita.

A figura 5.1 apresenta o modelo proposto em (Bernardes, 1999) para o SDI. Foge ao escopo deste trabalho uma descrição detalhada desse modelo; entretanto, será fornecida uma breve descrição do sistema para contextualizar as discussões posteriores.

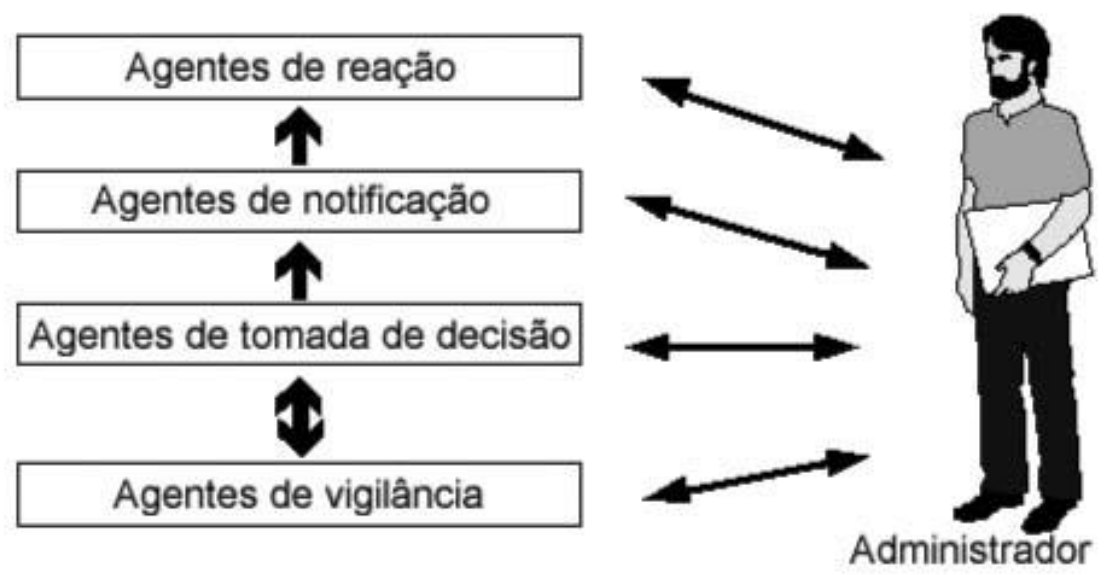

Figura 5.1: Arquitetura de um sistema de agentes móveis.

\section{Camada 1 - Agentes de Vigilância}

Essa camada representa o primeiro nível de agentes do sistema proposto. É composta por um conjunto de agentes móveis especializados (dotados de uma fração mínima da inteligência do sistema) e agentes estáticos (as sondas de captura de pacotes). Os agentes estáticos são responsáveis pela coleta de informações da rede. São eles que possuem acesso direto as informações presentes na rede e selecionam os pacotes segundo um filtro pré-configurado.

Os agentes móveis desempenham o papel de 'canal de comunicação assíncrono' entre os diversos agentes de captura estáticos situados em segmentos de rede distintos. Com isso, consegue-se ampliar o escopo de aplicação do SDI, efetuando a comunicação de seus módulos 
através de segmentos distintos da rede. Além disso, são responsáveis pela análise inicial dos alarmes gerados pelas sondas de captura. Caso o nível de segurança pré-estabelecido seja ultrapassado ${ }^{1}$, agentes da camada superior são contactados e, conforme a situação, disparam agentes especializados através do ajuste de sondas de captura com um filtro específico para cada situação. A camada de agentes de vigilância é o foco do presente trabalho e será discutida em detalhes na próxima seção.

\section{Camada 2 - Agentes de Tomada de Decisão}

São responsáveis por exercer todas as funções de tomada de decisão no sistema (motor de análise), constituindo a 'inteligência' do mesmớ. Um agente dessa camada irá receber uma mensagem ou um conjunto de dados dos agentes da camada inferior (a camada de vigilância) e, com base no exame criterioso dessas informações, poderá identificar uma intrusão (ou tentativa). Pode acionar novos agentes de vigilância para a coleta de informações complementares.

\section{Camada 3 - Agentes de Notificação}

Essa é a camada menos carregada em quantidade de agentes. São responsáveis, com base nas mensagens recebidas da camada 2, por notificar o administrador da rede e acionar os agentes da próxima camada (agentes de reação). Dessa forma, toda vez que os agentes de tomada de decisão identificarem um nível de periculosidade acima do aceitável ou a necessidade de atualização de algum novo padrão identificado, os agentes de notificação entrarão em ação.

\section{Camada 4 - Agentes de Reação}

Essa camada apresenta um conjunto de agentes que serão acionados pelos agentes da camada anterior ou pela ação direta do administrador. São responsáveis pelo emprego de contra medidas, recuperação e reconfiguração do sistema. Esses agentes representam a última linha de defesa do sistema.

Vale a pena observar que, as reações adotadas devem ser consideradas com extremo cuidado. A capacidade de reação de um SDI também pode ser explorada por um atacante. Em um sistema marcado pela forte dependência por essa característica, é possível realizar ataques a este módulo (também conhecido como countermeasure-box ou C-box (Ptacek and Newsham, 1998)) com o intuito de gerar reações adversas a sistemas legítimos. Esse padrão de ataque é quase imperceptível e pode tornar o invasor imune às medidas de segurança empregadas pelo sistema.

\footnotetext{
${ }^{1}$ Como ilustrado no modelo proposto em (Cansian, 1997).

${ }^{2}$ Assunto abordado em outro trabalho em desenvolvimento no grupo de segurança (Ambrósio, 2002).
} 


\subsection{Ambiente de implementação do modelo}

Uma estação gerenciadora de segurança possui os quatro contextos que representam as camadas do SDI. Cada camada constitui um contexto do sistema (o modelo proposto é mostrado na figura 5.1). O sistema foi desenvolvido utilizando o ASDK (Aglets Software Development Kit) e os conceitos relacionados são inspirados nas definições fornecidas por Danny Lange e Mitsuru Oshima (Lange and Oshima, 1998); autores do ambiente.

O contexto supracitado, pode ser definido como:

"Um objeto estacionário que promove os meios para a manutenção e gerenciamento de aglets (agentes) em execução, em um ambiente uniforme, onde o sistema hospedeiro é seguro contra aglets maliciosos... Contextos são nomeados e assim, podem ser localizados a partir de uma combinação contendo seu nome e o endereço do servidor." (Lange and Oshima, 1998)

No ASDK, a representação para um contexto é implementada através do servidor Tahiti $^{3}$. O servidor Tahiti é uma implementação dessa arquitetura contendo um daemon de rede cuja função é monitorar a rede em busca de agentes e um gerenciador de segurança que protege a máquina hospedeira.

As estações sob vigilância são portadoras de uma instância do ambienteTahiti cuja função é executar os agentes enviados pela estação gerenciadora. Em um primeiro momento, os agentes enviados são responsáveis pela busca de dados preliminares que indiquem intrusões (agentes da camada de vigilância). Os dados carregados pelos agentes são de cunho gerencial. Transmitem unicamente informação de controle. A formatação desses alertas poderia seguir o padrão proposto pelo MITRE (brevemente apresentado na seção 2.2.3).

\subsection{Novas inclusões ao sistema: camada de agentes de vigilância}

Os agentes dessa camada constituem os alicerces sob os quais toda a lógica do sistema é estruturada. Com base nas informações fornecidas (principalmente pelo agente de captura), os demais agentes do sistema irão tomar suas decisões. Segundo o modelo apresentado em (Bernardes, 1999), esses agentes realizam ações de monitoramento, coleta de informações, testes de ambiente e ajustes de configuração a partir de perfis de segurança, alocados de forma estratégica no ambiente ao qual se quer proteger.

\footnotetext{
${ }^{3}$ A utilização do ASDK (Aglets Software Development Kit) e seus componentes incluindo o servidor de agentes Tahiti é justificada através do trabalho desenvolvido em (Pereira Filho, 2001)
} 
Para apresentar as funcionalidades desenvolvidas para o agente de captura descrito no modelo, foi necessário modelar o comportamento de todos os demais agentes presentes nessa camada do sistema. Assim, foi possível determinar as alterações necessárias para a adaptação do agente de captura projetado inicialmente para atender as necessidades do sistema desenvolvido em (Cansian, 1997) e atualizá-lo de forma a se adequar aos cenários descritos em (Bernardes, 1999). As atualizações propostas para o agente de captura englobam alterações em sua arquitetura original de modo a se adequar ao ambiente de agentes móveis e um estudo relativo a aplicação da tecnologia de sniffing em ambientes de rede chaveados.

Um modelo contendo as principais interações da camada de vigilância foi detalhado. Vale a pena destacar que as interações (intercâmbio de informações) entre os agentes dessa camada foram desenvolvidas de modo a prover os dados necessários ao agente de captura. As especificações dos agentes fornecidas a seguir, visam atender as necessidades do agente de captura. Alguns agentes foram inseridos de modo a incrementar as funções previstas no modelo original (agente de interface e agente de pré-seleção de dados). As funções dos demais agentes baseiam-se em (Bernardes, 1999); entretanto, o detalhamento alcançado foi realizado para atender as necessidades previstas para o presente trabalho.

\subsubsection{Agente de interface}

Em termos de funções acumuladas, esse é o agente da camada de vigilância que possui o maior conjunto de ações especificadas. Entretanto, vale a pena observar que as funções desempenhadas por ele são de cunho gerencial. Pode ser considerado a espinha dorsal da camada de vigilância. Efetua os processos de envio (dispatching) e recuperação (retracting) dos agentes. O envio dos agentes é realizado no momento de início do sistema e a recuperação, quando for necessária a atualização de um determinado agente.

Os métodos diretamente relacionados com essas atividades (Lange and Oshima, 1998) são:

public final void Aglet.dispatch(URL destination)

Envia o agente (ou aglet) ao local (contexto) especificado pelo argumentodestination.

AgletContext.retractAglet (URL contextAddress, AgletID aid)

O método retractAglet, no contexto do agente de interface, permite que os agentes previamente disparados sejam recuperados de maneira assíncrona. Os parâmetros aid e contextAddress referem-se a um identificador (único) para o agente e seu contexto origem respectivamente. 
Como fica claro no modelo de SDI especificado em (Bernardes, 1999) (figura 5.1), o administrador possui participação ativa em todas as camadas do sistema. O agente responsável por processar as informações recebidas/fornecidas pelo administrador na camada de vigilância é o agente de interface. Os dados fornecidos pelo administrador ao agente de interface incluem:

- Lista de hospedeiros;

- Lista de usuários;

- Lista de serviços;

- Dados de limiar de recursos;

- Lista de estações de captura;

- Dados/atualizações sobre scans;

- Dados/atualizações sobre backdoors;

- Dados sobre a política de segurança.

A explicação detalhada sobre cada um destes atributos será fornecida na subseção correspondente ao agente responsável por processá-los. No decorrer do funcionamento do sistema, o administrador possui participação ativa, podendo inserir novos dados ou atualizar dados antigos, sem a necessidade de reinício do sistema inteiro. Para a introdução desses dados, basta efetuar a recuperação (retracting) do agente relacionado e inserir os dados a serem modificados.

Caso algum agente da camada de vigilância julgue necessário contatar a camada de agentes de tomada de decisão para obter maiores informações sobre uma determinada suspeita, a circunstância é encaminhada ao agente responsável na camada superior. Existindo a necessidade de refinamentos na coleta da informação, os dados são enviados ao agente de interface que irá disparar o agente solicitado com os parâmetros definidos pela camada superior.

\subsubsection{Agente de verificação de hospedeiros}

É responsável pela verificação dos hospedeiros em execução no ambiente. Esse agente pode transpor segmentos de rede desde que existam elementos roteadores para direcionar o tráfego. É de extrema importância em três circunstâncias: 
- Inicialização do sistema - No momento de inicialização do sistema, o agente de verificação de hospedeiros precisa de um indicativo dostatus (online/offline) das estações pertencentes a 'rede de vigilância' (as máquinas da rede que abrigam um ambiente servidor de agentes). Ele utiliza uma lista contendo uma relação de hospedeiros legítimos do sistema e a utiliza como itinerário. Caso a estação de gerenciamento sendo introduzida possua as permissões necessárias, o servidor sendo visitado atualiza sua entrada contendo o status dessa estação e declara-se online. Caso contrário, declara-se offline e não aceita os agentes provenientes dessa estação. O mecanismo de autenticação entre os ambientes de agentes móveis ainda não foi especificado. Após realizar sua verificação pelo status dos servidores do sistema, retorna a estação gerenciadora e atualiza sua lista local.

- Atualização da lista de hospedeiros - O agente de verificação de hospedeiros também pode ser usado para atualização da lista de hospedeiros presentes no sistema. Caso o administrador julgue necessário adicionar/remover estações monitoradas, ele pode atualizar a lista de hospedeiros do agente de verificação de hospedeiros na estação gerenciadora por intermédio do agente de interface. Para isso, o agente de verificação de hospedeiros é ativado e é requisitada a atualização de sua lista de hospedeiros original com base nos novos dados fornecidos. Existem duas possibilidades:

- Atualização de dados - Implica na remoção da lista de hospedeiros utilizada anteriormente no sistema.

- Inserção de dados - Anexa os novos dados a lista original.

- Divulgação de informação de hospedeiros a outros agentes- As lista de agentes legítimos presentes no sistema devem ser divulgadas a outros agentes dessa camada sob determinadas circunstâncias. Isso será explicado posteriormente.

Os modelos de dispersão (ou envio) de agentes utilizados pelo agente de verificação de hosts podem ser:

- Envio de clones - Envio de cópias do agente a todos os hosts legítimos, com cada um deles realizando sua verificação e retornando a estação gerenciadora para atualizar sua base de dados local. Após cumprir sua meta, o clone é destruído. A função do ASDK relacionada a clonagem de agentes é:

public final Object Aglet.clone()

- Utilização de itinerário - Sendo uma entidade móvel autônoma, um agente baseado em itinerário pode navegar independentemente através de múltiplos hosts. Ele deve, especificamente, estar apto a lidar com exceções (exceptions) como por exemplo a 
existência de hosts desconhecidos enquanto tenta enviar (dispatch) agentes a novos destinos. Também pode ser necessário modificar seu próprio itinerário, dinamicamente, dependendo de informações locais presentes nos sistemas alvo (como descrito em (Lange and Oshima, 1998), capítulo 8).

Os benefícios inerentes a cada uma dessas soluções não são objeto de estudo deste trabalho. A grosso modo, a flexibilidade do modelo baseado em itinerário pode ser compensada pela velocidade de resposta do modelo baseado em envio de clones. Para efeito dessa discussão, a escolha de qualquer um dos padrões descritos não irá influenciar na obtenção do resultado final pretendido para o sistema.

Como pôde ser observado, a função original desse agente foi ampliada. Optou-se por anexar as funções de atualização e divulgação, apenas para manter a coerência com a arquitetura proposta em (Bernardes, 1999). Vale a pena observar que, as funções anexadas a esse agente podem ser delegadas a outros agentes. Por exemplo, poderiam ser criados dois novos agentes, mais simples, sob a tutela do agente de verificação de hospedeiros incumbidos das funções de atualização e divulgação da lista de hospedeiros. As vantagens referentes a essas estratégias podem ser avaliadas em trabalhos futuros.

\subsubsection{Agentes de verificação de usuários conectados ao sistema}

São responsáveis pela obtenção de uma lista contendo os usuários conectados a um servidor, a hora de início e a origem do acesso. Além disso, é responsável pela manutenção de uma base de dados que contém informações sobre usuários legítimos do sistema. Esses dados incluem:

- Nome de usuário;

- Lista de domínios válidos para cada usuário.

Alterações/atualizações na base de dados contendo a lista de usuários e/ou a lista de domínios válidos, podem ser realizadas pelo administrador por intermédio do agente de interface. A lista de usuários pode ser inteiramente fornecida pelo administrador e mantida na estação gerenciadora ou baseada na lista obtida a partir de algum serviço de autenticação de usuários (como o NIS) presente no sistema. Também pode ser uma combinação desses métodos.

O agente de verificação de usuários conectados ao sistema é enviado (dispatching) pela estação gerenciadora de segurança, através do agente de interface, às estações sob monitoramento. Os endereços dessas estações são obtidos a partir do agente de verificação de hospedeiros. Ao chegar ao destino, coleta as informações relativas aos usuários conectados 
naquele instante e seu domínio de origem. Os modelos de dispersão usados para a especificação desse agente seguem os padrões apresentados na seção anterior (agente de verificação de hospedeiros).

Devido a natureza sensível das informações coletadas (bem como o acúmulo dos dados

e conseqüente 'inchaço' do agente), é recomendável que o modelo baseado em envio de clones seja utilizado em detrimento do modelo baseado em itinerário. A obtenção desses dados pode ser realizada, por exemplo, através da utilização de um comando who em uma estação Unix like.

Após coletar as informações sobre os usuários no sistema remoto, o clone retorna a estação gerenciadora, registra os dados obtidos e é eliminado. Esses dados podem ser armazenados em um arquivo específico para cada endereço verificado. A execução desse agente deve ser periódica.

\subsubsection{Agentes de verificação de usuários suspeitos}

Uma vez concluída a atividade dos agentes de verificação de usuários conectados ao sistema, esse agente efetua uma comparação entre a lista contendo os usuários válidos e a lista contendo os usuários conectados naquele instante. Em caso de identificação positiva, os dados são informados a um agente responsável na camada superior ou ao administrador. A implementação desse agente encontra-se bastante incipiente no momento. Sua função básica é identificar usuários 'estranhos' que não tenham sido previamente cadastrados no sistema.

Futuramente deve ser realizado um estudo entre a relação existente entre os agentes de verificação de usuários suspeitos e os agentes de configuração de profiles. Talvez seja necessária a inserção de um novo agente que realize uma operação de matching entre os perfis de usuário existentes e o comportamento corrente do usuário. Isso poderia caracterizar um mecanismo de identificação por anomalia anexado ao SDI original.

Cada identificação positiva é armazenada em um arquivo específico para o sistema verificado. Isso possibilita, a longo prazo, uma análise de histórico no sistema.

\subsubsection{Agentes de sondagem (scanning)}

Ao ser disparado pelo agente de interface, o agente de scanning recebe um endereço alvo para sondagem ou é requisitado a fazer uma busca no sistema inteiro. É recomendável que seu modelo de dispersão seja baseado em itinerário para evitar algum comprometimento do sistema. Com isso, a avaliação é realizada em uma máquina por vez, seguindo uma lista de endereços.

É composto por um conjunto de agentes que, através de tentativas de quebra de segurança, irão validar os serviços, processos e demais atividades que vão contra a política 
de segurança do ambiente. Empregam os mesmos princípios aplicados a ferramentas de avaliação de vulnerabilidades (discutidas na seção 3.2). Sua grande vantagem é a característica de expansão. Ao contrário de uma ferramenta comum, esse agente não possui todas as características de sondagem concentradas em um único 'programa central'. Esse agente é composto por uma entidade central que contém referências a outros agentes que possuem funções específicas para desempenhar um determinado tipo de avaliação.

Por exemplo, sob sua tutela podem estar agentes de sondagem de portas, agentes de busca por vulnerabilidades em um dado serviço e assim por diante. Cada um é especializado em detectar uma falha específica. Com o passar do tempo, novos furos de segurança serão detectados. Para que esse agente possa identificá-los basta inserir um agente especializado na detecção desta nova falha.

As falhas de sistemas descobertas são registradas e armazenadas na estação gerenciadora. Uma forma interessante para guardar essa informação é classificando-a por endereço. Assim, cada máquina possuiria um histórico de eventos detectados.

No momento de identificação de um determinado evento, seus dados podem ser enviados ao agente de interface com o propósito de informar o administrador ou o agente de tomada de decisão responsável por obter maiores informações. É um agente de execução periódica.

\subsubsection{Agente especializado em identificação de backdoors}

Com base nos padrões conhecidos e divulgados, irá rastrear o sistema em busca de backdoors. Esse agente deverá ser bastante flexível quanto a sua capacidade de reconfiguração, relevante a inserção de novos conhecimentos adquiridos. Observe que esse tipo de ataque pode ser caracterizado como um subconjunto dos ataques descanning, porém, possuem uma complexidade maior ${ }^{4}$.

Com relação a estrutura, esse agente segue o mesmo padrão utilizado pelo agente de scanning. Uma entidade central que possui vários subordinados sob sua tutela. Seu modelo de dispersão também é baseado em itinerário. Assim como o agente descanning, esse agente possui execução periódica. As vantagens e a motivação para o uso desta arquitetura já foi apresentada na discussão relativa ao agente de scanning e não será repetida.

Dentre os agentes sob o comando do agente especializado em identificação de backdoors, existe um responsável pela obtenção de uma lista de vulnerabilidades identificadas pelo agente de scanning na máquina sob proteção, com o objetivo de procurar por padrões que indiquem a presença de algum backdoor conhecido (data reasoning).

\footnotetext{
${ }^{4}$ Backdoors são caracterizados pela exploração de um conjunto de vulnerabilidades com o objetivo de estabelecer um ponto de entrada pré-determinado para o invasor.
} 
Caso falhe nessa primeira tentativa, então é realizada uma série de sondagens em busca de padrões conhecidos que caracterizem um determinadobackdoor. Essas explorações são realizadas através de agentes especializados na identificação de backdoors conhecidos no sistema. Para cada backdoor conhecido existe um agente especializado em sua detecção.

Caso uma falha seja encontrada pode ser notificada ao administrador (por intermédio do agente de interface), ou ao agente responsável na camada superior. Esse agente deve ser executado periodicamente.

\subsubsection{Agente de verificação de serviços}

Agente responsável pela verificação dos serviços em execução em máquinas servidoras em um dado instante. Efetua a manutenção de uma base dados que irá armazenar/disponibilizar uma lista contendo os serviços em execução. Seu padrão de armazenamento de informações segue os moldes descritos em agentes anteriores.

Esse agente é enviado às máquinas servidoras monitoradas pelo sistema (esse dado pode ser obtido a partir do agente de verificação de hospedeiros). Sua função é análoga ao comando ps disponível em sistemas Unix. Uma instância desse agente é enviada a cada estação sob proteção. O modelo de dispersão seguido pode ser via envio de clones ou através da utilização de um itinerário pré-definido (como visto na seção 5.3.1). Possui execução periódica.

\subsubsection{Agente de validação de serviços}

É o responsável pela validação dos serviços em execução. Cabe a ele a configuração do perfil que autoriza a execução de um ou mais serviços em uma máquina/servidor do ambiente. Obtém as informações sobre os serviços sendo executados a partir do agente de verificação de serviços. Caso identifique um serviço clandestino em execução, registra o fato e emite um aviso ao agente de monitoria de serviços com o intuito de obter maiores informações sobre a razão para a execução de tal serviço.

Esse agente deve permanecer na máquina sob vigilância a menos que seja solicitado explicitamente pela estação gerenciadora de segurança. Possui execução periódica. O modelo seguido pode ser via envio de clones (como visto na seção 5.3.1).

\subsubsection{Agente de monitoria de serviços}

É o responsável por monitorar as requisições de entrada dos serviços da rede. A lista de serviços (válidos) a serem monitorados é obtida a partir do agente de validação de serviços. 
Esse agente deve possuir uma base de conhecimento contendo a descrição do comportamento previsto para os serviços sob vigilância.

Caso identifique algo suspeito, notifica o administrador por intermédio do agente de interface, ou encaminha os dados preliminares sobre o serviço ao agente especializado da camada superior (a decisão de encerrar o serviço ou não, não cabe a esse agente).

O funcionamento desse agente é semelhante ao de um wrapper (como visto na seção 2.3.2). Esse agente deve permanecer na máquina sob vigilância a menos que seja solicitado explicitamente pela estação gerenciadora de segurança (ou seu timeout se esgote). O agente de monitoria de serviços possui execução periódica. O modelo de dispersão utilizado pode ser via utilização de itinerário (como visto na seção 5.3.1).

\subsubsection{Agente de verificação de utilização de recursos do sistema}

Agente responsável por monitorar a utilização de recursos de sistema como CPU e disco rígido, em momentos considerados estratégicos e não-críticos. Esse agente pode ser utilizado para efetuar um balanceamento de carga em nível de aplicação, levando em consideração principalmente a atividade crítica desempenhada pelo agente de captura.

Outra ação que pode ser anexada a esse agente (embora aumente consideravelmente sua complexidade) é a capacidade de correlacionar a utilização do recurso a um perfil de usuário. Essa informação é de suma importância para as funções desempenhadas pelo agente de configuração de profiles.

Para cada recurso monitorado pode ser criado um agente específico de monitoramento sob sua tutela. Após recolher as informações do sistema, retorna a estação gerenciadora e armazena os dados. A partir desses dados é possível compor um histórico de utilização do sistema. O modelo seguido para sua disseminação pode ser via envio de clones ou através do uso de itinerário (como visto na seção 5.3.1).

\subsubsection{Agentes de configuração de profiles}

Com base na percepção de novas formas de intrusão (variações do perfil de utilização dos usuários), procede com as devidas (re)configurações do sistema. Os arquivos utilizados por esse agente irão conter informações que refletem padrões de utilização normal do sistema. Alguns exemplos de atributos considerados nos perfis de usuário são: os horários de conexão dos usuários, estatísticas de utilização de dispositivos do sistema, procedência da sessão, entre outros.

As informações pertinentes aos horários de conexão e procedência da sessão podem ser obtidas a partir do agente de verificação de usuários conectados ao sistema. As estatísticas 
de utilização de dispositivos estão disponíveis por intermédio do agente de verificação de

utilização de recursos do sistema. Através dessas informações, o agente de configuração de profiles pode estabelecer um perfil para cada usuário do sistema, ou para cada sistema monitorado, utilizando os conceitos envolvidos em detecção de intrusão por anomalia citados na seção 3.1.3.

Caso detecte atividade suspeita, ele informa o agente responsável na camada superior, ou notifica o administrador através do agente de interface. Esse agente pode ser estático pois as informações necessárias ao seu funcionamento estão disponíveis na estação gerenciadora. Possui execução periódica.

\subsubsection{Agente de pré-seleção de dados}

Outra necessidade presente na camada de vigilância é a realização de uma triagem inicial dos dados coletados, de modo a minimizar a análise desnecessária de eventos, que estejam em conformidade com o padrão de utilização normal do sistema. Com isso, introduz-se mais um nível de filtragem de modo a delegar apenas a atividade de análise efetiva aos agentes da camada superior. Essa função era realizada pelo módulo de pré-seleção e sistema especialista (PSE) na implementação original do SDI desenvolvido no ICMC (Cansian, 1997). A proposta desse agente é portar as atividades realizadas pelo PSE, utilizando as vantagens inerentes ao emprego de código móvel.

Ele é responsável pelo disparo dos agentes estáticos distribuídos pelos ambientes servidores, configurados para captura, ao longo da rede. Para que isso seja realizado, alguns parâmetros são ajustados pelo agente de interface através de arquivos previamente definidos ou por intervenção direta do administrador. Esses parâmetros incluem:

- Uma lista contendo as estações de captura definidas para a rede de vigilância;

- Um filtro de captura padrão a ser utilizado pelo agente de captura.

A lista contendo as estações de captura deve ser comparada a lista dehosts legítimos do sistema (obtida pelo agente de verificação de hospedeiros) por ser um subconjunto da mesma. Isso é realizado para evitar a possibilidade de uso de estações que estejamoffline. É recomendado que as estações de captura executem apenas os agentes relacionados diretamente a captura de pacotes (agente de pré-seleção de dados e agente de captura); além de alguns agentes coadjuvantes. Os agentes considerados imprescindíveis se resumem ao agente de verificação de hospedeiros, o agente de verificação de utilização de recursos do sistema e o agente de interface. A utilização de servidores dedicados é recomendada para evitar o consumo de recursos críticos como HD ou CPU. 
Pode ser implementado um mecanismo de balanceamento de carga primário em nível de aplicação através da utilização dos dados fornecidos pelo agente de verificação de utilização de recursos do sistema. Com isso, caso o dispositivo de armazenamento ou a utilização de CPU encontre-se acima do limiar determinado, o agente de pré-seleção poderá utilizar uma lista redundante (contendo mais de uma estação de captura definida por segmento) para efetuar uma busca pela estação que atenda ao padrão de carga estabelecido. Note que este é um mecanismo de balanceamento de carga primário. O objetivo não é localizar a estação com menor carga e sim uma estação que atenda os parâmetros esperados para desempenhar a atividade de captura de forma satisfatória.

O modelo de disseminação utilizado para esse agente segue um itinerário pré-estabelecido (como visto na seção 5.3.1). Não existe a necessidade de efetuar um \&roadcast' de agentes como realizado por alguns dos agentes anteriores (através do modelo de clonagem). Após encontrar a estação adequada, o agente de pré-seleção de dados notifica a estação gerenciadora sua posição e inicia o agente de captura.

O agente de captura é configurado com um filtro pré-definido (ou estabelecido pelo administrador), cujo objetivo é minimizar a quantidade de tráfego a ser processado. Os pacotes inicialmente capturados são enviados ao agente de pré-processamento de dados através de comunicação via sockets ${ }^{5}$. Caso alguma suspeita seja detectada, o agente de captura é interrompido, os dados pertinentes a tentativa de intrusão armazenados, e o agente de pré-seleção de dados retorna a estação gerenciadora para informar o ocorrido ao administrador (por intermédio do agente de interface) ou encaminhar uma mensagem ao agente responsável situado na camada superior. Esse agente deve ser executado periodicamente.

\subsubsection{Proposta para a detecção preliminar dos ataques}

Como dito anteriormente, o agente de pré-seleção realiza uma filtragem inicial dos dados que possam representar interesse, como por exemplo, que tipo de protocolo deve ser monitorado, quais os serviços mais críticos, ou quais destinos ou origens devem ser considerados ou descartados. Os dados sobre esses eventos, provenientes dos pacotes previamente filtrados, são então analisado pelo agente de pré-seleção. A análise é baseada em estruturas de decisão e utiliza as seguintes informações:

- Quais os caminhos esperados de conexão (origem e destino da conexão), e quais podem representar risco;

- Quais as portas de origem e destino e, por conseqüência, quais os serviços envolvidos;

\footnotetext{
${ }^{5}$ Esse foi o mecanismo encontrado para efetuar a comunicação entre os módulos do programa escritos em linguagens de programação distintas - Java (código móvel) e linguagem C (código estático).
} 
- Sensibilidade das máquinas e confiabilidade dos domínios.

Estes dados servem como elementos de análise para monitoração dos eventos de risco, e vão determinar quando o sistema deve começar a capturar todos os dados de uma determinada conexão, para localizar as assinaturas de ataque (o processamento/desenvolvimento de assinaturas de ataques são atividades desenvolvidas por elementos da camada superior). Esses eventos são armazenados numa lista de monitoração (figura 5.2), que os mantém durante um tempo definido. Os dados colocados nessa lista tratam-se de vetores que incluem origem e destino da conexão, portas envolvidas, um 'nível de segurança' (NS) e um indicador horário. Cada conexão ou evento suspeito, é representado por um vetor na lista de monitoração.

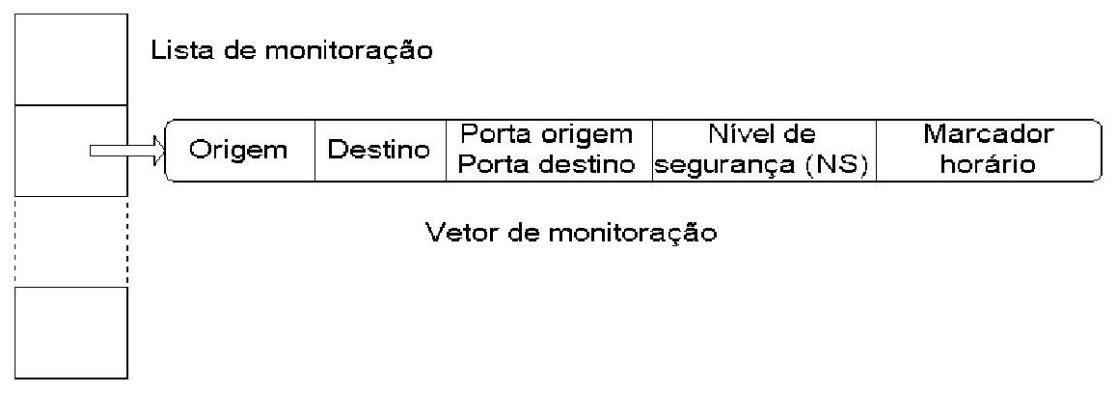

Figura 5.2: Representação do vetor de monitoração.

O nível de segurança (NS) é um valor numérico incrementado à medida que são monitorados eventos de interesse provenientes de uma dada origem. Esses eventos podem ser, por exemplo:

- Uma mesma origem fazendo acesso repetidamente a um mesmo destino na rede sob monitoramento;

- Um mesmo domínio de origem (ou subconjunto desse domínio) fazendo acesso, ou tentando fazer acesso a uma ou mais máquinas destino, na rede sob monitoramento.

Um exemplo para ilustração do uso do NS: o sistema detecta umfinger vindo do host externo A para o host B, na rede sob monitoramento e inclui um vetor para este evento na lista de monitoração, com um valor de nível de segurança pré-determinado para o finger $(\mathrm{NS}=2)$. Ao detectar um novo evento, por exemplo, um telnet (NS = 15), a lista de monitoração é pesquisada e, encontrando-se uma entrada proveniente da mesma origem/destino, o nível de segurança desse vetor existente é acrescido do valor do nível de segurança dotelnet, ficando com NS $=17$. Nesse caso, não é criado um novo vetor na fila. Pode ocorrer outra situação em que o evento detectado vem de um domínio (ou subrede) de onde já houve algum outro evento anterior (já registrado na lista), mas não necessariamente vindo da mesma máquina, nem possivelmente com o mesmo destino dentro da rede sob vigilância. Nesse caso um 
novo vetor é inserido na lista de monitoração, mas com o nível de segurança equivalente, acrescido de um peso indicando que já existe alguma ocorrência vinda daquele domínio. Outras variações podem ser facilmente expandidas, conforme necessário, a partir das duas situações principais descritas ${ }^{6}$.

A lista de monitoração é periodicamente verificada, dentro de um intervalo de tempo padronizado. Quando o campo do nível de segurança de um vetor atinge um limite pré-estabelecido, o agente de pré-seleção determina que o agente de captura passe a monitorar e capturar todos os dados daquela conexão ou, opcionalmente, de todas as conexões vindas daquele domínio. Há ainda a possibilidade de realizar diferentes tipos de buscas e verificações na fila, considerando-se não apenas o limite do NS para um par origem-destino, mas também no caso de domínios ou intervalos de endereços. Estas buscas podem resultar não apenas em atividades de monitoramento, mas também em ações de registro e auditoria, conforme a necessidade.

O agente de pré-seleção abre um socket para o agente de captura, cuja função é inserir os dados relevantes à análise de endereço origem, destino e serviços, para uma classificação segundo os níveis de segurança adotados. No ambiente de desenvolvimento, o pacote capturado contém: o cabeçalho Ethernet, o cabeçalho IP e por último o pacote de dados encapsulado nele, que pode ser tanto TCP, ICMP ou UDP. Em caso de redes chaveadas o pacote pode ainda possuir um cabeçalho $(\mathrm{tag})$ que contém dados referentes a VLAN no qual está inserido (maiores detalhes no capítulo 6).

Para a análise destes pacotes é necessário ter um acesso simplificado aos dados dos cabeçalhos. Para tal, deve-se mapear o pacote em certas estruturas de memória que seguem o formato especificado para esses protocolos. Para isso, utiliza-se os tipos de dados fornecidos pela linguagem de desenvolvimento (no caso do agente de captura, a linguagem $\mathrm{C}$ ). Olinux fornece bibliotecas de sistema contendo os mapeamentos de cabeçalho necessários. Elas oferecem toda uma gama de funcionalidades, para o acesso aos cabeçalhos (headers) e campo de dados (payload) dos pacotes. Vale a pena observar que graças a modularidade do agente de captura (inspirada no modelo proposto pelo tcpdump ${ }^{7}$ é possível inserir o mapeamento de novos pacotes sem alterar significativamente o código original. As seguintes características foram conferidas ao sistema:

- Flexibilidade-O sistema original apresentava uma tremenda dificuldade para inserção de novos protocolos de rede devido a característica centralizada de seu código. Com a estrutura do sniffer inspirada no modelo do tcpdump, tornou-se prática a inserção de novos campos de cabeçalho ao sistema. Basta, para isso, incluir novas bibliotecas

\footnotetext{
${ }^{6}$ As considerações sobre nível de segurança são de natureza empírica, como está registrado em (Cansian, 1997).

${ }^{7}$ Ferramenta open source disponível em ftp://ee.lbl.gov/tcpdump.tar.Z (visitado em 11-03-2001).
} 
contendo os mapeamentos relativos a cada novo cabeçalho. Essa solução é bem mais prática do que o código original.

- Suporte à integração com o sistema de agentes móveis - Como será visto posteriormente, a comunicação com o agente de captura estático (implementado em linguagem C) é imprescindível ao sistema. Esse agente deverá se comunicar com o agente de pré-seleção responsável por seu monitoramento.

- Filtro de pacotes dinâmico - Essa característica está diretamente relacionada com o ítem anterior. O 'filtro de pacotes dinâmico' refere-se ao disparo de agentes estáticos por agentes de pré-seleção de acordo com a situação.

De posse dos pacotes capturados, o agente de pré-seleção de dados começará a análise quanto ao tipo de serviço utilizado. As regras definidas (Cansian, 1997) para o desenvolvimento do agente de pré-seleção são:

- Pacotes TCP são tratados se representam uma conexão do tipo FTP, telnet, SMTP (mail), HTTP, Finger, POP3, rexec, rlogin, rsh e lpr,

- Pacotes UDP que representam conexões do tipobootp, sunrpc, rwho, syslog, talk, route e NFS são analisados;

- Pacotes ICMP que não representam ping serão descartados.

Caso o pacote atenda a essas regras, procede-se a análise e controle das conexões. Em (Cansian, 1997) utilza-se uma tabela de controle de conexões indexada segundo uma função hash. Essa função retorna o número da máquina em relação a sua rede, ou seja o último octeto de um número IP. Por exemplo, a máquina 143.107.231.211 teria uma entrada na posição 211 do vetor principal da tabela. Esta indexação está representada na figura 5.3.

Cada posição desta tabela será um ponteiro para uma lista que irá conter informações mais detalhadas sobre as conexões de todos os hosts que foram enquadrados neste índice pela hash. Cada nó desta lista possui, além do endereço do host correspondente (host origem), uma lista com todas as conexões realizadas por este na rede local, contendo um nível de segurança (NS) e uma referência ao próximo nó (próximohost). Cada nó da lista conexões conterá o IP da máquina em que foi feita a conexão (host destino), as respectivas portas de origem e destino (porta origem e porta destino) o tempo inicial (TS) e o último tempo de acesso (TL). Esta estrutura está representada na figura 5.4.

Os valores dos níveis de segurança definidos no projeto para cada um dos possíveis eventos e serviços de rede, estão listado na tabela 5.1. 


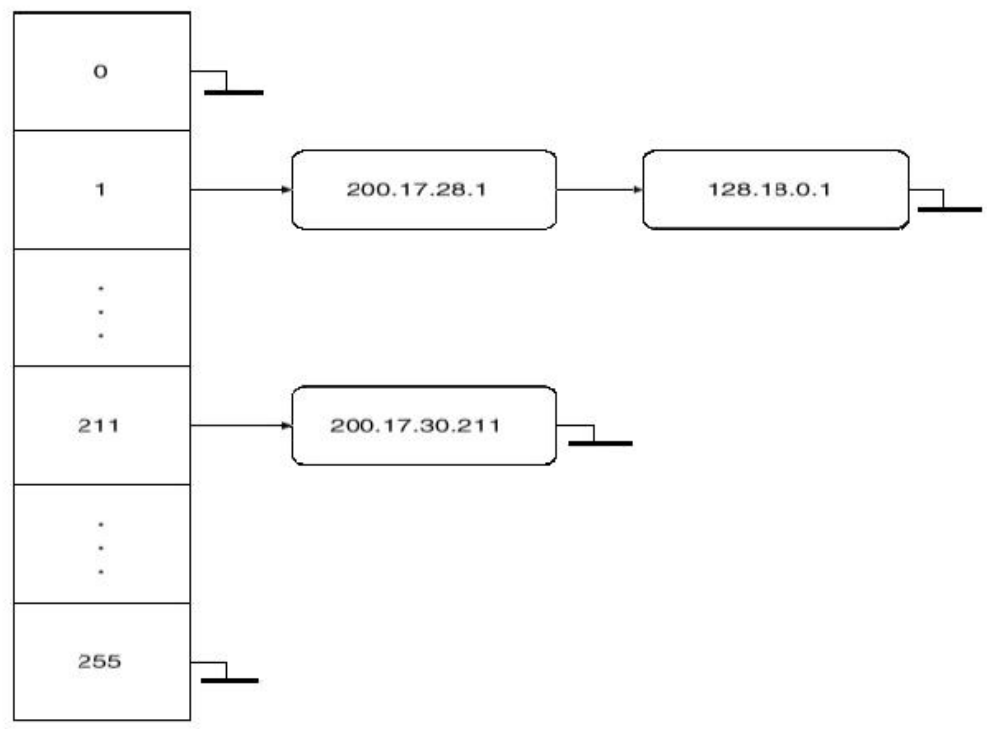

Figura 5.3: Representação da Tabela de Controle de Conexões (TCC).

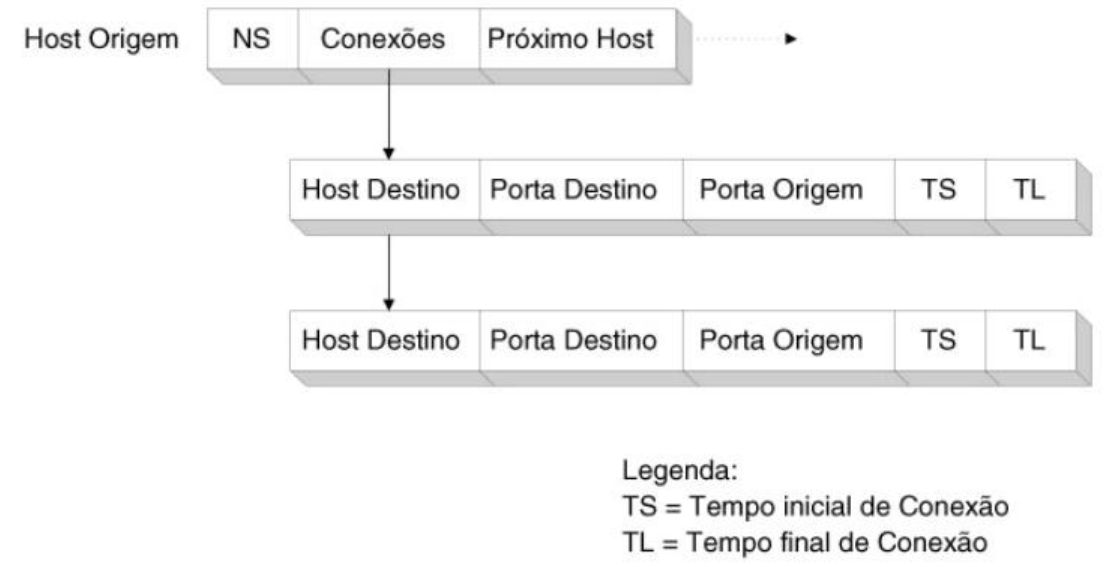

Figura 5.4: Estrutura interna da TCC.

Esses valores foram calculados com base nas capacidades de cada serviço. Otelnet, por exemplo, oferece mais capacidade (e portanto mais risco de intrusão) do que of inger, portanto possui um NS maior. Os valores de TS e TL são importantes para se proceder uma análise periódica e cíclica da tabela. Assim, certas conexões serão removidas após um determinado tempo de vida, uma vez que se decida que elas não são mais relevantes para a análise de intrusão.

Baseado nos níveis de segurança, o administrador da rede define um limiar máximo (threshold) para o valor de NS. Se o NS de uma entrada ultrapassar este limiar, o host e o domínio ao qual este pertença passam a ser considerados potencialmente perigosos para a rede. Neste momento o agente de pré-seleção envia um alerta para o agente especializado da camada superior. 


\begin{tabular}{|c|c|c|}
\hline Protocolo / Porta & NS & Serviço \\
\hline TCP / 21 & 15 & FTP \\
TCP $/ 23$ & 15 & Telnet \\
TCP $/ 25$ & 5 & SMTP \\
UDP $/ 67$ & 10 & Bootp \\
TCP $/ 79$ & 2 & Finger \\
TCP $/ 110$ & 5 & Pop3 \\
UDP $/ 111$ & 10 & SunRPC \\
TCP $/ 512$ & 5 & Exec \\
UDP $/ 513$ & 10 & Rlogin \\
TCP $/ 514$ & 15 & Rsh \\
TCP $/ 515$ & 10 & Lpr \\
UDP $/ 520$ & 10 & Route \\
UDP $/ 2049$ & 15 & NFS \\
Outras & 1 & Outras portas não listadas (default) \\
\hline
\end{tabular}

Tabela 5.1: Valores de NS, referentes as portas, adotados no agente de pré-seleção para determinar o disparo automático do agente de captura.

\subsubsection{Agente de captura de pacotes}

Agente que trabalha em modo promíscuo na rede efetuando a captura de pacotes presentes no barramento. Esse agente representa a base de todas as funções dependentes de fontes de informação network based do sistema baseadas em detecção por uso indevido (ou signature based). Devido a natureza complexa desse agente, não foi possível implementá-lo utilizando apenas código Java como o restante do sistema.

Isso se deve a descoberta tardia de uma solução para captura de pacotes em Java ${ }^{8}$. Graças a esse empecilho, as atividades relativas a captura de pacotes foram realizadas através da implementação parcial do sistema em linguagem C ANSI utilizando-se uma API específica para captura de pacotes. É importante ressaltar que, ao contrário do restante do sistema (que é multi-plataforma), a aplicação representada pelo agente de captura estático é específica de ambientes UNIX like.

Esse agente estático reside em uma estação servidora de agentes cuja função específica será efetuar a captura de pacotes em um segmento de rede. Como foi dito anteriormente, a estação de captura não precisa ser um servidor dedicado, entretanto, devido a natureza delicada dos dados coletados, essa condição evita a utilização dos recursos por outros agentes de natureza menos crítica. A priori, devem ser executados na estação de captura apenas as instâncias do agente de captura (estático e móvel) e os agentes coadjuvantes necessários ao seu funcionamento.

\footnotetext{
${ }^{8}$ Jpcap - uma biblioteca para captura de pacotes utilizada para o desenvolvimento de aplicações em java. Referência: http://jpcap.sourceforge.net (visitado em 06/04/2002). A última versão desta biblioteca foi liberada em 31/03/2002.
} 
Na implementação do agente de captura estático foi utilizada a biblioteca de funções libpcap v0.4 (Jacobson et al., 1992) para a comunicação com o dispositivo de rede. A libpcap é uma implementação do BPF (BSD Packet Filter) rápida, eficiente e de simples utilização. Esta biblioteca é também bastante versátil pois permite a captura não apenas de pacotes Ethernet, mas também de pacotes PPP (Point-to-Point Protocol) e SLIP (Serial Line Protocol), IPX, SPX entre outros, bastando para isso que o programador conheça o seu formato.

\subsubsection{BSD Packet Filter}

Muitas versões do UNIX possuem ferramentas para captura de pacotes, tornando possível o uso de estações de trabalho para o monitoramento da rede. Como esses monitores são executados no nível do usuário, os pacotes devem ser copiados do núcleo do sistema operacional (kernel) para o nível do usuário antes de poderem ser analisados.

Este processo de cópia pode ser minimizado desenvolvendo-se um agente no kernel chamado de filtro de pacotes (packet filter), o qual descarta os pacotes desnecessários o mais rápido possível. O packet filter original do UNIX havia sido desenvolvido sobre um filtro baseado em pilhas, caracterizado por baixa performance nos atuais processadores RISC. O BPF (BSD Packet Filter) (Jacobson et al., 1992) usa uma nova abordagem, com um filtro baseado em registradores; abordagem 20 vezes mais rápida do que a implementação original. O BPF também usa uma estratégia de straightforward buffering, que torna sua performance até 100 vezes mais rápida do que o NIT da Sun (Sun Microsystems Inc., 1990) executando na mesma máquina.

O BPF possui dois componentes principais: o interceptador de rede (network tap) e o filtro de pacotes. O interceptador de rede coleta cópias dos pacotes do dispositivo de rede e as entrega às aplicações que as estão monitorando. O filtro decide se o pacote será aceito e em caso positivo, quanto do mesmo será copiado para a aplicação.

Quando um pacote chega a interface de rede, olink-level device driver envia o mesmo para uma pilha de protocolos do sistema. Mas quando o BPF está "escutando" esta interface, o driver primeiro chama o BPF. Este por sua vez envia o pacote para cada filtro associado com cada processo monitorando a rede. Cada filtro decide se o pacote será aceito e quantos bytes deverão ser lidos. Para cada filtro que aceita o pacote, o BPF copia a quantidade de dados pedida para o buffer associado (figura 5.5). O controle então é devolvido ao dispositivo de rede, e os procedimentos normais do protocolo de comunicação seguem adiante.

Como normalmente os processos de monitoramento devem verificar cada pacote na rede, e o tempo entre os pacotes pode ser de apenas alguns microssegundos, não é possível fazer uma chamada de leitura do sistema por pacote. Assim, o BPF coleta os dados de vários pacotes e os retorna como uma única unidade. Quando o processo de monitoramento faz a 


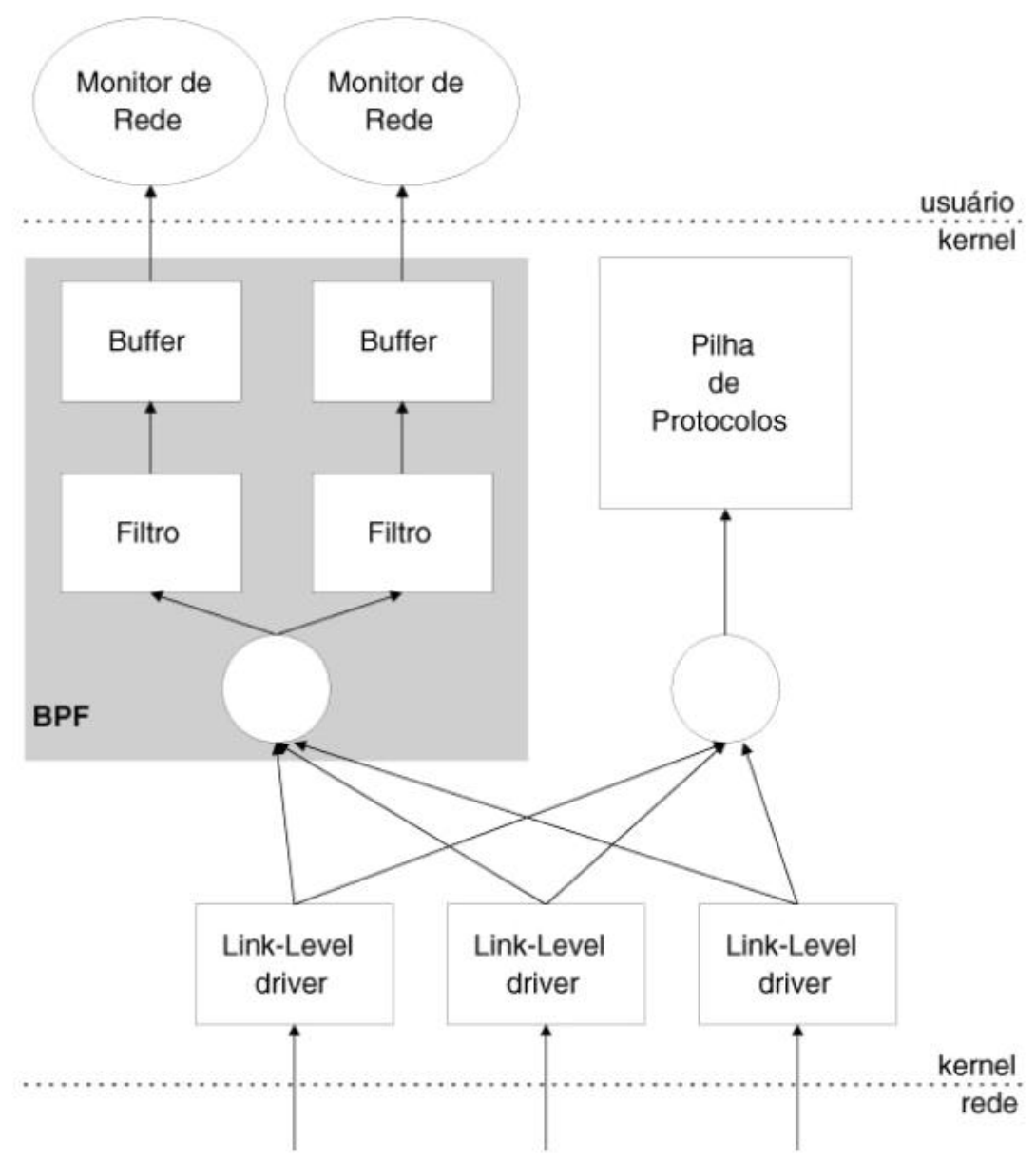

Figura 5.5: Funcionamento do BPF.

leitura, encapsula os dados capturados de cada pacote com um cabeçalho que inclui umtime stamp, um comprimento e um deslocamento para o alinhamento dos dados.

Como os processos de monitoramento precisam apenas de um pequeno subconjunto do tráfego de rede, um grande aumento de performance é conseguido filtrando os pacotes indesejados no lugar onde o DMA (Direct Memory Access) do dispositivo de rede os coloca, ao invés de copiá-los para algum outro buffer do kernel e filtrá-los depois. Então, se o pacote não é aceito, somente os bytes necessários para o processo de filtragem são referenciados.

O modo de operação normal do dispositivo de rede não permite o acesso a pacotes que não sejam destinados à máquina onde o sistema está sendo executado. No entanto, existe um modo de operação, chamado de modo promíscuo (Hunt, 1998), que permite o acesso a todos os pacotes trafegados em um mesmo segmento de rede. O modo promíscuo, entretanto, é garantido apenas ao usuário supervisor da máquina (conhecido como root). Por tal motivo o agente de captura estático deve ser executado com prioridade de supervisor. 


\subsubsection{Biblioteca de captura - libpcap}

Utilizando as funções fornecidas pela libpcap, o dispositivo de rede é colocado em modo promíscuo e é definido um filtro de pacotes para a interface. O agente passa a receber uma cópia de cada pacote para o qual a regra definida no filtro é verdadeira. Um exemplo de filtro definido como portador de uma instrução a ser compilada nokernel é:

"tcp or udp or icmp and ( not src net <rede_local>)"

Isso significa que somente pacotes do tipo TCP, UDP ou ICMP, cujo endereço origem não seja nenhuma máquina pertencente à rede que o sistema esteja monitorando, serão capturados.

As principais funções da libpcap utilizadas para a implementação do agente são:

pcap_t *pcap_open_live( char *device, int snaplen, int promisc, int to_ms, char *errbuf )

pcap_open_live é utilizada para retornar um descritor que referenciará o dispositivo de rede. device é uma cadeia de caracteres que especifica o dispositivo a ser aberto,snaplen especifica o número máximo de bytes a serem capturados, promisc indica se o dispositivo deve ser ajustado para modo promíscuo ou não, to_ms especifica o timeout de leitura entre pacotes em milisegundos, errbuf é usado para retornar uma mensagem de erro no caso de falha da função ao abrir o device.

char *pcap_lookupdev ( char *errbuf )

pcap_lookupdev retorna uma seqüência de caracteres que indicará o dispositivo de rede apropriado a ser utilizado. Essa informação é usada como a opçãodevice nas funções pcap_open_live e pcap_lookupnet descritas acima. Caso ocorra um erro, a função retorna NULL e errbuf é preenchida com uma mensagem de erro apropriada.

int pcap_compile ( pcap_t *point_device, struct bpf_program *filter, char *string, int optimize, u_long netmask )

pcap_compile é usada para compilar a instrução de filtragem contida em string dentro da estrutura filter do tipo bpf_program (estrutura interna da biblioteca libpcap) que será usada depois em pcap_setfilter. O campo point_device é o descritor retornado 
por pcap_open_live. O campo optimize define se deve ou não ser feita uma otimização no resultado final da compilação do filtro. O camponetmask é a máscara da rede local.

int pcap_setfilter ( pcap_t *point_device, struct bpf_program *filter)

pcap_setfilter é usada para ativar o filtro filter compilado com a função anterior na interface de rede referenciada por point_device.

int pcap_dispatch ( pcap_t *point_device, int qt, pcap_handler callback, u_char *user )

pcap_dispatch é utilizada para coletar e processar pacotes, qt especifica o número máximo de pacotes a serem processados antes de retornar. Se qt for igual a -1 a função processa todos os pacotes recebidos em um único buffer; se qt for igual a 0 a função processa todos os pacotes até que ocorra um erro ou um EOF (End of File) seja atingido. callback é um ponteiro para a função que será chamada para tratar os pacotes coletados pela pcap_dispatch. Essa função necessariamente deve possuir três parâmetros: um ponteiro do tipo u_char o qual é passado pela pcap_dispatch (parâmetro user) para identificação da origem do pacote, um ponteiro para uma estrutura pcap_pkthdr que receberá algumas informações sobre o horário em que o pacote foi coletado e um ponteirou_char (que é o pacote capturado). O número de pacotes lidos é o retorno da função e se for igual a -1 indica um erro.

As estruturas pcap_t e pcap_handler são internas à biblioteca e não serão discutidas aqui. u_char e u_long são, respectivamente, unsigned char e unsigned long.

No momento em que o agente de captura estático é iniciado, ele obtém a partir de sua contra-parte móvel, os dados referentes ao filtro que será compilado nokernel. Em seguida, ele desempenha (rigorosamente nessa ordem) as seguintes tarefas:

- Verifica se está executando com prioridade de supervisor;

- Identifica o filtro padrão;

- Inicializa o processo como daemon;

- Salva o número do processo (pid) para um arquivo de referência (lockfile);

- Procura por um dispositivo de rede (função pcap_lookupdev);

- Inicializa o dispositivo encontrado (função pcap_open_live); 
- Obtém o endereço e a máscara da rede (função pcap_lookupnet);

- Compila a instrução de filtragem (função pcap_compile);

- Ativa o filtro no kernel para a interface de rede (função pcap_setfilter);

Caso alguma destas tarefas falhe, a execução é interrompida imediatamente. Em caso de sucesso é utilizada a função pcap_dispatch que enviará os pacotes capturados a uma outra função definida para enviá-los aos módulos seguintes onde serão feitas as análises.

\subsubsection{Mensagens de comunicação entre o agente de captura e o agente de pré-seleção de dados}

Como foi dito anteriormente, a comunicação entre o agente estático e o agente de pré-seleção é realizada via sockets devido a utilização de linguagens de programação distintas para a implementação do sistema. O agente de pré-seleção deve possuir a capacidade de criar o socket (lado servidor) para se comunicar com o agente de captura estático (lado cliente). O protocolo de comunicação escolhido para a implementação dosocket foi o TCP/IP devido a natureza crítica dos dados a serem transmitidos pelo canal. O canal deve ser confiável, pois deve garantir a entrega dos pacotes sendo transmitidos pelo agente de captura estático.

Em resumo, o mecanismo utilizado para a criação dosocket pelo lado servidor respeita os seguintes passos:

1. Abrir um socket servidor (ServerSocket) em uma porta acima de 1023;

2. Criação de um objeto socket (a partir de ServerSocket para ouvir (listen) e aceitar (accept) conexões;

3. Abertura de canais de entrada e saída (streams). Isso é realizado através dos objetos BufferedReader para o canal de entrada e PrintWriter para o canal de saída;

4. Utilização do método readLine() (de BufferedReader) para a monitoração do canal de entrada;

5. Utilização do método println() (de PrintWriter) para a comunicação com o sniffer.

O agente estático (sniffer), por sua vez, realiza os seguintes passos para se comunicar com o socket criado pelo agente móvel:

1. Criação do socket (socket (AF_INET, SOCK_STREAM, 0)) e obtenção de uma referência para acessar o mesmo (file descriptor); 
2. Efetua a conexão ao socket Java criado pelo agente móvel. Utiliza o nome do host e a porta para efetuar essa tarefa $($ connect ()$)$;

3. Utiliza as funções read() e write() para realizar o controle do canal de comunicação. O canal de entrada é usado para o recebimento de instruções (de incialização ou ainda parâmetros de encerramento para o programa) e o canal de saída para a geração de relatórios ao agente móvel.

Outra opção, mais elegante para a realização da comunicação entre o agente móvel e o agente estático advém da utilização de Java Native Interface (JNI). O JNI é a solução da Sun para a transposição de código nativo (por exemplo códigoC) em uma classe Java (java class). Basicamente, é definido um ponto de referência para o qual uma classe Java pode efetuar uma chamada a uma biblioteca carregada estaticamente, que irá executar a parcela de código nativo e retornar novamente a classe original. Uma abordagem mais aprofundada em JNI foge ao escopo do trabalho e será relegada a um trabalho futuro. Além disso, com o surgimento de uma biblioteca para a captura de pacotes implementada emJava, o esforço despendido para a conversão do estado atual de desenvolvimento para a abordagem JNI pode revelar-se desnecessária.

\subsubsection{Comportamento do sistema}

De posse da especificação dos agentes da camada de vigilância, é possível apresentar uma descrição do comportamento do sistema. A característica principal do agente de captura desenvolvido reside na obtenção de informações utilizando um sistema de análise com inteligência limitada (agente de pré-seleção), fornecendo apenas um subconjunto da informação capturada (informações de cabeçalho) para os agentes inteligentes situados na camada superior (motor de análise). Esses agentes inteligentes irão avaliar as informações obtidas, funcionando como 'gatilhos' para a ativação de outros agentes de captura com filtros ajustados de forma a refinar suas conclusões (figura 5.6).

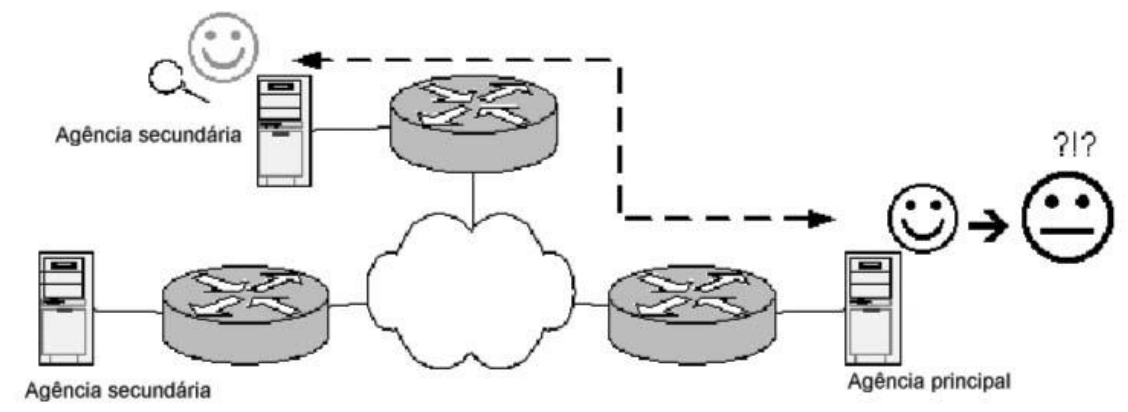

Figura 5.6: Exemplo de uma execução do agente de captura (Tavares et al., 2002). 
O sniffer descrito na seção 5.3.13 pode ser anexado a um agente móvel (que pode ser o próprio agente de pré-seleção) e configurado com filtros pré-determinados (que caracterizam o tipo de protocolo monitorado, o serviço utilizado, etc.) pelo administrador do sistema ou pelos agentes da segunda camada. A função desse filtro é selecionar as informações essenciais para o motor de análise evitando o exame desnecessário de informação pelo agente de pré-seleção, o que poderia acarretar uma possível lentidão em sua transmissão. À medida que o motor de análise necessitar de informações mais específicas, novos agentes de captura são requisitados.

No exemplo da figura 5.6, o agente é ativado pelo administrador ou por um agente responsável (situado na camada de vigilância ou na camada superior) e enviado a uma agência localizada em outro segmento de rede. Após a captura das informações e constatação de algum evento suspeito, o agente de pré-seleção retorna à agência de origem e transmite os dados obtidos ao motor de análise. Dependendo da situação e das informações capturadas, o agente inteligente localizado na camada superior decidirá o curso de ação a ser seguido. Dentre as opções viáveis, pode ocorrer o envio de outros agentes de captura configurados com filtros apropriados, ou ainda, o acionamento de outros agentes inteligentes especializados.

A anexação do agente de captura ao agente móvel é interessante em um ambiente broadcast. Isso permite a conversão de qualquer estação secundária portando o ambiente de agentes móveis em uma estação de captura. Em caso de aplicação aswitches, essa solução não é muito interessante pois a estação de captura é uma máquina específica conectada a porta de captura. Com isso, o transporte ou permanência do agente para a estação de captura não é importante.

\subsection{Considerações sobre a arquitetura descrita}

Com relação a arquitetura descrita, foram feitas considerações sobre a inserção de novos agentes no sistema e a manutenção de alguns trechos através da inserção de agentes especializados (como no caso dos agentes de verificação de backdoors e scanning). Deve ser realizado um estudo para a solução do problema de aging dos agentes previamente inseridos. Quando esses agentes são considerados obsoletos? É necessária uma política para a remoção de agentes visando evitar o 'inchaço' descontrolado das camadas do SDI descrito.

Além disso, existe a necessidade de revisão dos procedimentos de comunicação entre os agentes de captura e pré-seleção de dados. No presente contexto, o agente de pré-seleção interrompe a execução do agente de captura e com isso existe a possibilidade de novos ataques deixarem de ser registrados. Para isso, o par agente de pré-seleção/agente de captura deve ser substituído por algo semelhante a agente de monitoramento/agente de captura. 
O agente de monitoramento passa a ser um novo nível de abstração entre o agente de pré-seleção e o agente de captura. As atividades de controle do agente de captura seriam conferidas a esse novo agente isolando as funções de pré-seleção da responsabilidade de controle do agente de captura.

\subsection{Sumário}

O objetivo desse capítulo foi apresentar o contexto no qual o SDI do ICMC está inserido. Com isso, foi apresentada a arquitetura modular do sistema introduzida em (Bernardes, 1999). Para o escopo desse trabalho, a camada de maior relevância no modelo é a camada de vigilância, pois é nela que se encontram os alicerces de todo o sistema. Dessa forma, inspirado nos cenários previamente modelados, foi desenvolvida uma especificação detalhada para a camada de vigilância e a interação entre seus agentes.

Os resultados obtidos em (Pereira Filho, 2001) são utilizados para tecer considerações sobre a implementação do sistema. Assim sendo, o ambiente de desenvolvimento considerado foi o ASDK (Aglets Software Development Kit). Além disso, o uso desses agentes leva-nos a acreditar que vantagens serão alcançadas em detrimento de sistemas tradicionais. Por exemplo, a modularidade proporcionada é ímpar quando comparada a outras soluções. Isso fica bastante claro nas especificações, por exemplo, do agente de scanning e do agente de verificação de backdoors. Para expandir o escopo da aplicação basta introduzir novos agentes especializados.

As considerações aplicadas para o agente de captura englobam a utilização da biblioteca de captura de pacotes (libpcap) e a utilização de código C para o seu desenvolvimento. A conseqüência imediata do desenvolvimento desse agente foi a introdução de um novo agente, cuja origem remonta ao trabalho desenvolvido em (Cansian, 1997). O agente de pré-seleção, entre outras funções, desenvolve o papel de filtro inicial para os pacotes capturados pelo agente de captura. Sua introdução no sistema fez-se necessária, principalmente considerando ambientes com volume de tráfego elevado no qual o sistema pode ser aplicado. O estudo do cabeçalho desempenhado pelo agente de pré-seleção é um fator de suma importância para minimizar a análise indiscriminada de payload.

O próximo capítulo terá o objetivo de apresentar as limitações inerentes a arquitetura de SDIs com relação infraestrutura da rede sob vigilância. Considerações mais detalhadas sobre o comportamento do agente de captura serão realizadas de forma a reforçar a necessidade por um sistema desta natureza. 
74 CAPÍTULO 5. ARQUITETURA DO SISTEMA: ORIGINAL E NOVAS INCLUSÕES 


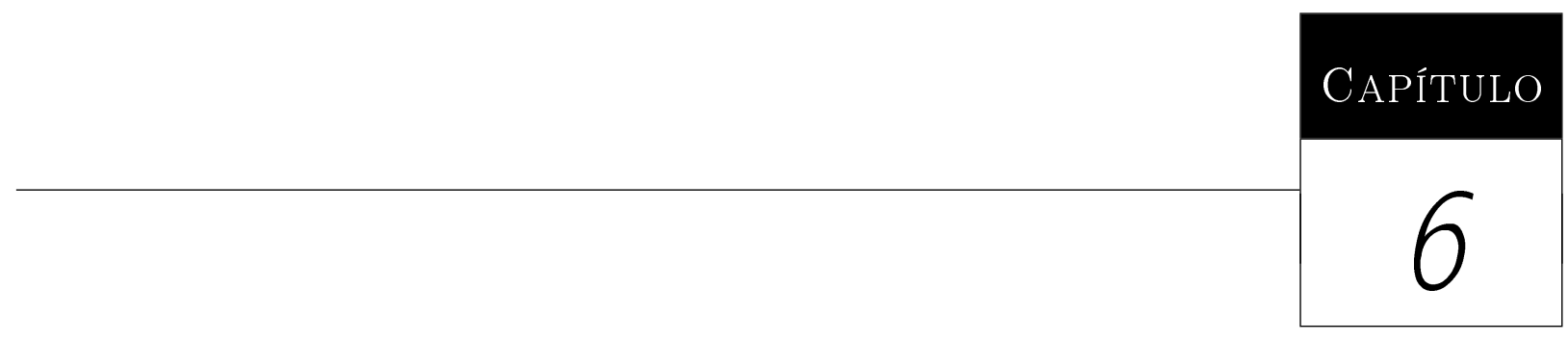

\section{Infraestrutura de hardware e sua influência no sistema}

Apesar de ser uma parcela bastante reduzida do sistema, pode-se dizer que, a partir da especificação do funcionamento da camada de vigilância (principalmente com relação a comunicação entre agentes), é possível realizar um procedimento análogo para o desenvolvimento das demais camadas. Os passos relativos a especificação da camada de vigilância e de seus agentes foram apresentados no capítulo 5. Nessa camada, o agente que representa o foco de estudo é o agente de captura. Qual o impacto da infraestrutura da rede sobre esse agente? Por ser de vital importância para a coleta de informações da rede, foi realizado um estudo procurando indícios de que o funcionamento desse agente seria aplicável a arquitetura de rede chaveada. De certa forma, as limitações e progressos relativos ao agente de captura possuem impacto direto sobre todo o sistema.

\subsection{Agente de captura baseado em análise de vulnera- bilidades}

Um dos maiores problemas existentes em redes de computadores é a complexidade crescente de sua topologia. Com isso, sua arquitetura tem se tornado mais hierarquizada através da separação dos domínios de colisão em segmentos distintos da rede. Apesar dos benefícios inerentes ao emprego de novos equipamentos (como switches, roteadores, etc.), a aplicação de técnicas de captura para o monitoramento de redes tem se tornado cada vez mais ineficaz. 
A maior polêmica sobre a tecnologia de sniffing gira em torno de sua aplicação em dispositivos de chaveameto (switches). Ao contrário de um HUB, o switch verifica a quem o pacote é endereçado e estabelece uma conexão particular entre os participantes da sessão. Mesmo assim, o receptor analisa o endereço do frame para determinar se, de fato, aquele pacote lhe pertence.

Embora essa dupla verificação cause uma pequena sobrecarga no host, esse é um processo necessário para evitar a migração não autorizada de máquinas (como por exemplo notebooks) de um segmento de rede a outro. Com isso, é fácil observar que uma rede chaveada não pode ser monitorada através do emprego de mecanismos de software convencionais utilizados em redes broadcast. Isso se deve a não existência de tráfego compartilhado no meio. Perceba também que, dentre os benefícios supracitados, o acréscimo ao nível de segurança da rede não é considerado. Caso o switch não seja configurado de maneira apropriada, ele constitui um meio tão vulnerável quanto uma rede compartilhada. É possível explorar as vulnerabilidades de um dispositivo mal configurado e, dessa forma, conseguir um resultado similar ao obtido por um sniffer em ambiente broadcast.

Essa seção irá apresentar algumas tecnologias consideradas para aplicação no agente estático de captura de pacotes (o sniffer). Nesse conjunto encontram-se implementações desenvolvidas puramente em software (muito semelhantes as ferramentas de análise de vulnerabilidades mencionadas no capítulo 3).

\subsubsection{Vulnerabilidades de switches}

O desenvolvimento de redes chaveadas está diretamente relacionado a necessidade por maior largura de banda. Embora exista um acréscimo significativo ao nível de segurança da rede, essa não é a principal motivação para a utilização dessa tecnologia. Uma investigação mais detalhada revela que existem vários métodos disponíveis para osniffing de redes chaveadas. Alguns deles, descritos em (Sipes, 2000), são:

- ARP Spoofing;

- MAC Flooding;

- MAC Duplicating.

Essas três opções serão discutidas em maiores detalhes a seguir. Note que existem outras maneiras de realizar o sniffing de redes chaveadas, que são descritas na documentação das ferramentas mencionadas posteriormente. Para o escopo da discussão referente aos ataques, serão considerados três nós em uma rede chaveada: A, B e C. A e C serão as entidades que desejam efetuar uma comunicação legítima, enquanto B será o nó hostil. 


\subsubsection{ARP Spoofing}

Uma das operações básicas do protocolo Ethernet refere-se a geração de requisições (request) e respostas (reply) ARP (Address Resolution Protocol). Em geral, quando um nó A deseja se comunicar com um nó $\mathrm{C}$, ele envia uma requisição ARP. O nó $\mathrm{C}$ irá enviar uma resposta ARP que irá incluir o endereço MAC. Mesmo em um ambiente chaveado, a requisição ARP inicial é enviada via broadcast. É possível para um nó B compor e enviar uma resposta ARP não solicitada ao nó $\mathrm{A}$. Esta falsa resposta $\mathrm{ARP}$ irá especificar que o nó $\mathrm{B}$ tem o endereço MAC do nó C. Com isso, o nó A irá inconscientemente enviar o tráfego ao nó $\mathrm{B}$, já que este declara que possui o endereço MAC desejado. Algumas ferramentas disponíveis são especializadas no envio de falsos pacotes ARP a classes de máquinas (por exemplo, servidores NFS, HTTP, etc.). Um exemplo deste tipo de ferramenta é o dsniff (visto na seção 3.2), recomendada para capturar tipos de tráfego específicos. Outras ferramentas concentram-se nos pedidos ARP em geral e enviam respostas falsas logo em seguida. O programaparasite ${ }^{1}$ pertence a essa categoria e captura o tráfego de toda a rede. Para que esse tipo de ataque funcione, é necessária a habilidade de enviar (forward) frames recebidos aos seus hosts origem. Isso é possível através de algum tipo de IP forwarding em nível de kernel ou aplicação.

\subsubsection{MAC Flooding}

Como já foi mencionado, switches são os responsáveis pelo estabelecimento de circuitos virtuais de um nó a outro. Para isso, eles devem manter uma tabela de tradução (translation table) que seja capaz de rastrear que endereços (especificamente, que endereços MAC) estão disponíveis em qual porta física. A quantidade de memória para essa tabela de tradução é limitada. Esse fato permite que o switch seja explorado para fins de sniffing. Em alguns switches, é possível efetuar um bombardeio com dados contendo endereços MAC aleatórios. Como o switch não sabe como lidar com o excesso de dados, ocorrerá um erro de falha de abertura de conexão (fail open). A conseqüência disso é que, ele se converterá em um HUB e irá efetuar um broadcast dos pacotes recebidos em todas as portas. Com isso, um sniffer genérico de rede irá ser o suficiente para a conclusão do serviço.

\subsubsection{MAC Duplicating}

Considerando que todos os frames em uma rede chaveada são roteados baseados em seus endereços MAC, a habilidade de personificar outro host seria bastante vantajosa. Esse é o objetivo do ataque conhecido como MAC duplicating. O nó B é reconfigurado de forma a possuir o mesmo endereço MAC da máquina cujo tráfego deseja-se capturar. Isso é possível em uma máquina linux, caso o indivíduo possua acesso privilegiado ao comando ifconfig.

\footnotetext{
${ }^{1}$ Disponível em http://packetstorm.widexs.nl/sniffers/parasite-0.5.tar.gz (visitado em 14/02/2002)
} 
O ataque de MAC duplicating difere do ARP spoofing pois, em realidade, o switch é levado a acreditar que existem duas portas com o mesmo endereço MAC. Considerando que os dados serão enviados a ambas as portas, não é necessário nenhuma prática de IPforwarding.

\subsubsection{Considerações sobre as técnicas de ataque descritas}

A primeira pergunta a ser feita é: 'Por que a técnica de captura de pacotes funciona tão bem quando aplicada a SDIs network based convencionais?'. Isso ocorre porque o sniffing realizado em redes broadcast é passivo (não existe alteração de tráfego). O monitoramento é transparente às máquinas sob vigilância.

As técnicas de ataque apresentadas na seção anterior poderiam ser usadas em SDIs, assim como acontece com outras ferramentas de segurança. Um exemplo são as técnicas utilizadas em ferramentas de avaliação de vulnerabilidades (como visto no capítulo 3). Os métodos descritos são os mesmos usados em ataques de scanning; entretanto, o contexto é fundamentalmente diferente.

No caso das técnicas apresentadas para captura de pacotes em switches, existiria a possibilidade de seu emprego em SDIs, não fosse o fato de que o tráfego da rede é adulterado e, em geral, a integridade do switch é comprometida. No caso da primeira abordagem (ARP spoffing), ao 'envenenar' as tabelas de roteamento internas, o tráfego que seria dirigido a uma máquina legítima é redirecionado a outra estação. O problema é que a máquina alvo sendo personificada perde os pacotes destinados a ela. Talvez essa técnica fosse melhor utilizada em padded cells ${ }^{2}$.

Considerando a técnica de MAC flooding, o problema resultante é causada pela quebra do paradigma de chaveamento. Com isso, perdem-se todas as vantagens inerentes ao uso de um switch e retorna-se ao ambiente broadcast conhecido. Essa não é uma questão a ser considerada.

O princípio de MAC duplicating seria interessante considerando-se apenas uma única máquina sob vigilância (talvez um servidor de alta disponibilidade da rede). Nesse caso é possível obter a captura passiva desejada. Entretanto, graças ao número elevado de máquinas a serem monitoradas em um switch tradicional, percebe-se que essa é um prática inviável. Segundo essa técnica não é possível proteger um grande número de máquinas através do processo de personificação efetuado por uma única estação gerenciadora de segurança.

\footnotetext{
${ }^{2}$ Em caso de um ataque confirmado em uma dada máquina, as tabelas de roteamento doswitch seriam deliberadamente envenenadas (considerando que o mesmo não perceba o fluxo de pacotes incomum gerado) com o intuito de confinar as ações desencadeadas pelo ataque a um ambiente controlado. As implicações dessa situação não são relevantes para o escopo do trabalho e não serão referenciadas.
} 


\subsubsection{Mecanismos de proteção contra os ataques descritos}

As técnicas de ataque apresentadas contra switches consideram equipamentos com configuração padrão (out of the shelf). Existem alguns métodos que podem ser utilizados para proteção contra esses ataques. Esses procedimentos são aplicáveis tanto a redesbroadcast quanto a ambientes chaveados.

\subsubsection{Algoritmos de Spanning Tree}

É um mecanismo que impede redes de grande porte com inúmerosswitches de entrarem em colapso devido a duplicação espontânea de MACs. Esses algoritmos permitem a formação de caminhos redundantes na rede sem a presença de ciclos (loops). Para que o algoritmo funcione de maneira adequada em switches de camada 2 ou 3, deve-se garantir que apenas um caminho ativo exista entre duas estações ${ }^{3}$.

Basicamente, é escolhido um switch na rede para ser o elemento raiz (root) e, a partir dele, é criado um grafo contendo um caminho único entre ele e os demais switches. É precisamente a implementação desse algoritmo que permite que uma rede chaveada, mesmo na iminência de um ataque a seus elementos chaveadores, continue funcionando sem a criação de ciclos. Caso o switch root falhe, é possível configurar um switch alternativo para assumir o seu lugar.

Diferente dos antigos bridges spanning tree, a aplicação desse algoritmo em switches é mais apurada, permitindo um controle em nível de portas. Uma rota pode ser construída de forma otimizada, priorizando-se os links mais rápidos de cadahop.

\subsubsection{IP Filtering}

Através da habilitação de IP filtering no switch, é possível definir o tráfego que será explicitamente permitido em cada porta. A adoção dessa medida pode representar um esforço monumental para as atividades de implantação e gerenciamento, especialmente se o ambiente for dinâmico.

\subsubsection{Port Security}

Se o switch possuir a capacidade para implementar segurança por porta, isto será de grande ajuda para proteção contra ataques de ARP spoofing e MAC flooding. Esse atributo previne efetivamente que o switch reconheça mais de um endereço MAC por porta física. Assim, como em outros procedimentos de segurança, o acesso ao ambiente é restrito,

\footnotetext{
${ }^{3}$ Fonte: http://www.cisco.com/univercd/cc/td/doc/product/lan/cat5000/rel_5_2/config/spantree.pdf
} 
aumentando a necessidade por um processo de gerenciamento, ou ainda, por um processo de auditoria.

\subsubsection{Routing Security}

O roteamento deve ser praticado apenas pelos roteadores designados. Isso significa que nenhuma estação deve possuir permissão para executar um protocolo de roteamento considerando o fato de que essas podem ser comprometidas. Além disso, deve ser ressaltado que qualquer manutenção dos mecanismos de rede deve ser executada através de uma conexão segura (SSH2 por exemplo) e não através de um telnet que expõem o nome e senha do administrador sem nenhum tratamento pela rede.

\subsection{Descrição dos recursos do switch}

Como ficou claro na seção anterior, não é possível implementar uma solução para a aplicação em switches puramente baseada em software. A solução adotada precisa utilizar recursos de hardware inerentes ao dispositivo, além do sistema descrito no capítulo anterior. Uma observação importante, é que os recursos para a análise de tráfego em mais baixo nível (em nível de cabeçalho de pacote e payload) disponíveis em switches ainda são muito limitados. Recursos, como por exemplo, listas de controle de acesso (ACLs) não podem ser aplicados a porta de captura. A aplicação deste recurso relegaria aohardware mais um nível de pré-filtragem do tráfego, auxiliando a coleta de informações realizada pela sonda de captura. Isso representaria um ganho de desempenho considerável para o sistema, que teria suas funções de filtragem implementadas em software simplificadas. Infelizmente, esse tipo de regra é apenas empregada para os canais de entrada (ou seja, nas portas que originam a sessão) e não em portas de destino, como é o caso de uma porta de captura ou espelhamento.

Atualmente o nível de gerenciamento dos switches chegou a um patamar no qual atividades complexas de gerenciamento podem ser implementadas no próprio dispositivo ou através da instalação de módulos dedicados (módulos dehardware acopláveis). De um modo geral, o mecanismo de software para análise de tráfego é baseado nas técnicas utilizadas em redes broadcast. Um sensor, ajustado em modo promíscuo (Hunt, 1998), é acoplado a uma porta de captura para a qual todo o tráfego (ou parte dele) é redirecionado. Para que esse mecanismo funcione efetivamente, é necessário que o dispositivo possua suporte a portas de captura para o redirecionamento de tráfego.

De maneira bastante sucinta, as tecnologias que serão discutidas ao longo do capítulo, relativas às características inerentes ao switch e que podem ser usadas em benefício do SDI proposto, são: 
- VLANs (Virtual LANs) - Permitem a construção de domínios de colisão sem a restrição de conexões físicas.

- Portas de captura ou espelhamento (Port mirroring) - Condiciona um switch a copiar todo o tráfego associado com uma ou mais portas a uma porta destino, denominada porta de captura ou de espelhamento. A porta de captura pode ser conectada a um analisador de rede ou sonda RMON (Remote Monitoring) para a análise de pacotes.

Os conceitos relacionados a VLANs serão utilizados posteriormente nas discussões referentes a configuração da porta de captura no switch. Esses ítens são de suma importância e serão abordados em detalhes. A aplicação dessas características particulares constituem o elemento chave para a obtenção de uma solução diferenciada para captura de pacotes em switches. Vale a pena observar que, apesar de genérica, essa solução é baseada na utilização de um dispositivo de chaveamento particular (Extreme Networks, inc., 2000).

\subsubsection{Características do sistema inerentes aos switches}

Essa seção tem por objetivo descrever em detalhes as características mencionadas na seção anterior. Todas elas são inerentes ao hardware do switch e, para o contexto desse trabalho, tem por objetivo minimizar a quantidade de tráfego a ser analisado pela sonda de pacotes.

\subsubsection{VLANs (Virtual LANs)}

O termo VLAN é usado para caracterizar uma coleção de dispositivos que se comunicam como se estivessem presentes na mesma rede local (LAN física). Qualquer conjunto de portas (incluindo todas as portas do switch) é considerado uma VLAN. Nesse caso, contudo, os segmentos de rede não são restritos pelo hardware que os conecta fisicamente. São definidos dinamicamente através da classificação em grupos de usuários que possuem características semelhantes.

Uma VLAN pode ser definida como um grupo independente de localização e topologia (location and topology independent) que se comunica como se estivesse na mesma rede local. Sua utilização, no switch, facilita muitas atividades dispendiosas de administração com um conseqüente aumento de eficiência nas operações de rede.

Os benefícios decorrentes da utilização de VLANs podem ser resumidos da seguinte forma:

- VLANs auxiliam no controle do tráfego- Com as redes tradicionais, o congestionamento pode ser causado pelo tráfego broadcast que é dirigido a todos os dispositivos 
de rede, sem levar em consideração se isso é necessário. VLANs aumentam a eficiência da rede porque cada VLAN pode ser ajustada para conter apenas aqueles dispositivos que devem efetivamente se comunicar.

- VLANs proporcionam um acréscimo à segurança- A comunicação fica limitada a dispositivos membros de uma determinada VLAN. Caso seja necessária a comunicação inter-VLANs o tráfego deve cruzar um dispositivo de roteamento.

- VLANs facilitam a mudança e o deslocamento de dispositivos- Em redes tradicionais, os administradores desperdiçam muito tempo com mudanças e modificações de equipamentos. Se usuários se moverem para uma subrede diferente, os endereços de cada estação devem ser atualizados automaticamente.

\subsubsection{Características de VLANs}

Os atributos de VLAN incluem os seguintes campos:

- Nome;

- VLANid;

- Como a VLAN foi criada (manualmente ou via GVRP - Generic VLAN Registration Protocol);

- Endereço IP;

- Endereço IPX (caso configurado);

- Informação STPD (Spanning Tree Protocol Domain);

- Informação de protocolo;

- Informação referente ao perfil de QoS;

- Portas atribuídas;

- Status (Tagged/untagged) para cada porta;

- Como as portas foram adicionadas à VLAN (manualmente ou via GVRP). As VLANs podem ser classificadas seguindo os seguintes critérios:

- Porta física - Em VLANs baseadas em porta, um nome de VLAN é fornecido a um grupo de uma ou mais portas no switch. Após a designação de uma determinada porta, esta pode pertencer apenas ao grupo designado. 
- Tag 802.1Q - O processo de tagging refere-se a inserção de um marcador (ou tag) no frame ethernet. O tag contém o número de identificação de uma VLAN específica, chamado de VLANid. A vantagem estratégica de tagged VLANs é a habilidade de uma porta ser membro de múltiplas VLANs. Isso pode ser particularmente útil caso exista um dispositivo (como um servidor) que deva pertencer a múltiplas VLANs. O dispositivo deve possuir um NIC (Network Interface Card) que suporte o tagging 802.1Q.

- Protocolos - VLANs baseadas em protocolos habilitam a definição de um filtro de pacotes que é usado pelo switch como o critério de comparação para determinar se um pacote particular pertence a uma determinada VLAN. VLANs baseadas em protocolo são usadas mais freqüentemente em situações onde segmentos de rede contém hosts executando múltiplos protocolos. Caso seja necessário, é possível definir um filtro de protocolo específico baseado em EtherType, Logical Link Control (LLC), e/ou SubNetwork Access Protocol (SNAP). Até 6 protocolos podem ser parte de um filtro de protocolos.

- Endereços MAC - Permitem que portas físicas sejam mapeadas no endereço MAC origem adquirido na Forwarding Database ${ }^{4}$ (FDB). Essa característica permite designar um conjunto de portas que tenham sua associação de VLAN (VLAN membership) determinada dinamicamente pelo endereço MAC da estação que está ligada à porta física. O endereço MAC origem convertido ao mapeamento VLAN (source MAC address-to-VLAN mapping) pode ser configurado offline ou dinamicamente no switch.

- Uma combinação desses critérios.

\subsubsection{Portas de captura ou espelhamento (Port mirroring)}

De um modo geral, o mecanismo para análise de tráfego é inspirado nas técnicas utilizadas em redes broadcast. Um sensor (o dispositivo onde a análise de tráfego é efetuada), ajustado em modo promíscuo, é acoplado a uma porta de captura para a qual todo o tráfego (ou parte dele) é redirecionado. Para que este mecanismo funcione efetivamente em um switch é necessário que o dispositivo possua suporte a portas de captura ou (espelhamentơ). Esse método permite que o tráfego analisado seja baseado em monitoramento de portas do switch, VLANs ou algum tipo de tráfego designado pelo usuário.

- Porta física - Todos os dados que passam pela porta, sem levar em consideração a configuração da VLAN, são copiados para a porta de captura.

\footnotetext{
${ }^{4} \mathrm{E}$ uma base de dados contendo todos os endereços MAC recebidos em todas as suas portas. O switch usa a informação nesta base para decidir se um frame deve ser enviado (forwarded) ou filtrado.

${ }^{5}$ Designadas como Switch Port Analyzers ou SPAN ports nos equipamentos da Cisco
} 
- VLAN - Todos os dados provenientes de uma VLAN particular, sem levar em consideração a configuração da porta física, são copiados para a porta de captura.

- Porta virtual - Todos os dados específicos para uma VLAN, em uma porta específica, são copiados para a porta monitora.

Pode ser definida apenas uma única porta de captura ${ }^{6}$, possuindo até oito filtros de captura (mirroring filters) (Extreme Networks, inc., 2000). Uma vez que a porta é especificada como uma porta de captura, ela não pode ser usada para outras funções. Por esse motivo, a estação de captura acoplada possui outra interface (além da interface usada para captura) para efetuar uma conexão única para o envio de mensagens de controlê (figura $6.1)$.

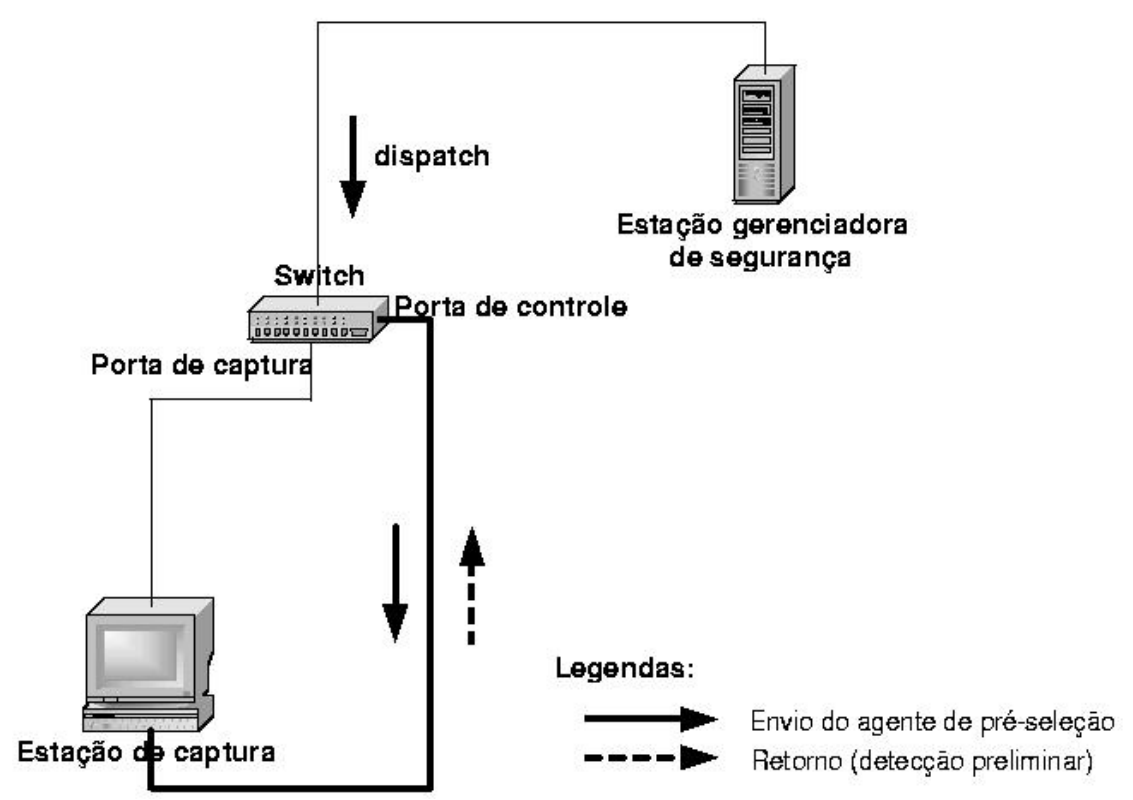

Figura 6.1: Posicionamento da estação de captura .

Em caso de uso de VLANS, os frames são encapsulados utilizando o padrão 802.1Q ou o ISL (Inter-Switch Link $^{8}$ ).

Independente da forma de encapsulamento, este mecanismo torna possível o envio de pacotes pertencentes a múltiplas VLANs multiplexadas em uma única conexão do switch

\footnotetext{
${ }^{6} \mathrm{O}$ número de portas de captura varia dependendo do dispositivo. Existem dispositivos que aceitam apenas uma única porta de captura no dispositivo enquanto outros aceitam uma porta de captura por módulo do switch.

${ }^{7}$ Baseado em dados coletados em: http://www.cisco.com/univercd/cc/td/doc/product/lan/cat6000/ios127xe/config/span.pdf

${ }^{8} \mathrm{Um}$ mecanismo proprietário da Cisco para encapsular pacotes com informações de VLAN e prioridade quando transmitidos pelo backbone. Permite que dois dispositivos se comportem como uma única entidade lógica.
} 


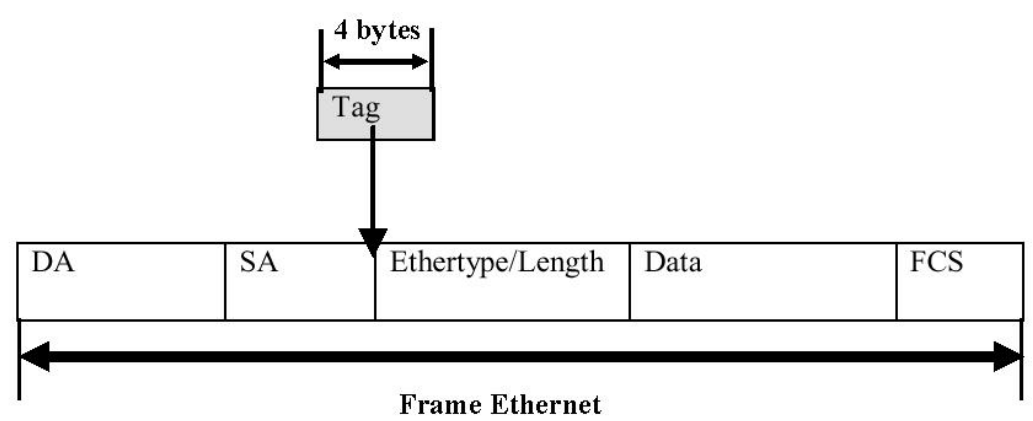

\begin{tabular}{|l|l|l|l|l|l|l|l|l|}
\hline \multicolumn{2}{|c|}{} & \multicolumn{5}{|c|}{ Tag Header } & \multicolumn{3}{|c|}{} \\
\cline { 2 - 8 } & TPID & \multicolumn{3}{|c|}{ TCI } & 1 \\
\hline $\begin{array}{l}48 \\
\text { bits }\end{array}$ & $\begin{array}{l}48 \\
\text { bits }\end{array}$ & 16 bits & 3 bits & 1 bit & 12 bits & 16 bits & $\begin{array}{l}\text { Variable } \\
\text { length }\end{array}$ & $\begin{array}{l}32 \\
\text { bits }\end{array}$ \\
\hline DA & SA & TPID & Priority & CFI & $\begin{array}{l}\text { VLAN } \\
\text { ID }\end{array}$ & $\begin{array}{l}\text { Length/ } \\
\text { Type }\end{array}$ & $\begin{array}{l}\text { Data with } \\
\text { PAD FCS }\end{array}$ & FC \\
\hline
\end{tabular}

Figura 6.2: Mapeamento de pacote encapsulado pelo 802.1q.

para enviar o tráfego a uma sonda acoplada a porta de monitoramento. Os delimitadores são tags especiais no caso do padrão 802.1Q (figura 6.2) e um encapsulamento completo do pacote no caso do padrão ISL. Este padrão também é usado para expandir a influência de uma VLAN a outros switches. Através de uma única ligação ao invés de $\mathbf{n}$ ligações (onde $\mathbf{n}$ é o número de VLANs interconectadas entre switches), é possível conectar um grande número de $\mathrm{VLANs}^{9}$

Para a aplicação do sistema em switches, uma série de fatores devem ser considerados, como por exemplo, formas de filtrar o tráfego redirecionado a porta de captura, de modo a otimizar o processamento da sonda. Infelizmente, observou-se que com os recursos atuais isso não foi possível. Os switches estudados não apresentavam características como:

- Emprego de listas de controle de acesso (Access Control Lists - ACLs) a porta de captura;

- Filtros de pacotes avançados de modo a minimizar o tráfego;

- Utilização de mais de uma porta de captura por módulo do switch.

\footnotetext{
${ }^{9}$ Esta prática é denominada truncking pela Cisco. Para maiores informações vide www-1.cisco.com/warp/public/473/27.html
} 
O último ítem mencionado é implementado em alguns core switches ${ }^{10}$ e merece atenção especial. Podem ser monitoradas portas contendo tráfego de entrada, saída ou ambos. Qualquer porta pode operar como porta de captura e, mais de uma porta pode ser usada para essa atividade. No caso desse dispositivo particular, podem ser especificadas até 64 portas para o espelhamento de tráfego. As portas de captura podem ser ajustadas em módulos diferentes ou mais de uma em um mesmo módulo. Por exemplo, as portas $1 / 1$ e $5 / 1^{11}$ podem ser configuradas para monitorar as portas $1 / 2-1 / 8$ na porta $1 / 1$ e as portas $5 / 2$ a $5 / 8$ na porta 5/1. Caso sejam configuradas mais de uma porta de captura no mesmo módulo, o tráfego redirecionado é espelhado a todas elas.

\subsubsection{Outras características do switch - Módulos SDIs}

Atualmente o grau de gerenciamento dos switches chegou a um patamar no qual atividades complexas de gerenciamento podem ser implementadas no próprio dispositivo ou através da instalação de módulos dedicados. Com isso, já existem switches que possuem atividades atribuídas a SDIs incorporadas, que podem desempenhar um conjunto de atividades mínimas para a descoberta de ataques em uma rede chaveada ${ }^{2}$. Como exemplo, pode ser citado o Catalyst 6000 Intrusion Detection System Module(IDSM) da Cisco que monitora pacotes da rede através de captura.

Em geral, a forma de análise empregada por esses módulos é baseada em análise de assinaturas de ataque que ficam armazenadas em uma base de dados estáticd ${ }^{3}$ ). Os pacotes capturados são reconstituídos e comparados a um conjunto de regras que representam atividades intrusivas típicas. Seria extremamente proveitoso incorporar algumas características destes sistemas ao SDI. Uma vantagem desta abordagem seria tirar proveito de atividades automatizadas pelo módulo dedicado, como por exemplo, seus mecanismos de resposta a incidentes. O SDI poderia contribuir nesta 'simbiose' através de um maior grau de adaptabilidade; imprimindo um caráter dinâmico a base de dados de assinaturas de ataque, aproveitando-se dos benefícios proporcionados pela camada de agentes de tomada de decisão.

\footnotetext{
${ }^{10} \mathrm{Um}$ exemplo de dispositivo que possui essa característica é oFastIron 4802 desenvolvido pela Foundry. Fonte: http://www.foundrynet.com/services/documentation/sribcg/Global_Features.html\#24933 (visitado em $22 / 04 / 2002)$

${ }^{11}$ Essa notação refere-se a slot (ou módulo)/porta do switch.

${ }^{12}$ Para maiores detalhes vide:

http://www.cisco.com/univercd/cc/td/doc/product/iaabu/csids/csids5/csidscog/overview.pdf

${ }^{13}$ Esta base deve ser atualizada manualmente, em contraste com o sistema adaptativo proposto pelo em (Cansian, 1997) e (Bernardes, 1999).
} 


\subsection{Sumário}

Como ficou bem elucidado no capítulo referente a discussão de sistemas detectores de intrusão, essa tecnologia possui uma grande dificuldade de adaptação em redes segmentadas. O dispositivo utilizado para subdividir os diversos segmentos de rede é denominadoswitch e foi abordado em detalhes nesse capítulo. Embora proporcione um aumento no nível de segurança da rede, através da separação dos domínios de colisão, esse dispositivo possui suas fraquezas. Caso não seja configurado de forma adequada, é tão vulnerável quanto a arquitetura de uma rede broadcast. Foram descritos os ataques que poderiam ser aplicados em uma solução baseada em avaliação de vulnerabilidades para a captura de pacotes, entretanto, como uma solução dessa natureza quebra o paradigma de chaveamento, foi totalmente desconsiderada.

A solução mais adequada procura usar recursos presentes no switch; mais especificamente referente a portas de captura e VLANs. Infelizmente, as opções de filtro desenvolvidos para portas de captura ainda são muito pobres, delegando toda a responsabilidade de filtragem inicial dos pacotes ao agente de pré-seleção descrito no capítulo anterior. Além dessa opção, existe a possibilidade de utilização de módulos especialistas desenvolvidos para detecção de intrusão, entretanto, devido ao custo do equipamento, não foi possível realizar uma análise mais aprofundada dessa tecnologia.

Com relação ao modelo de SDI, fica claro que o sistema utilizando agentes móveis é flexível o bastante para ser aplicado a uma rede chaveada. Com relação ao desempenho, uma análise mais aprofundada deve ser desempenhada para comprovar a eficácia do sistema em desenvolvimento. 
CAPÍTULO 6. INFRAESTRUTURA DE HARDWARE E SUA INFLUÊNCIA NO 


7

\section{Conclusões e Proposta para Trabalhos Futuros}

Nesse capítulo, além das conclusões obtidas ao longo do projeto, serão apresentadas uma série de propostas de continuidade para o trabalho aqui apresentado. Uma delas, é o desenvolvimento análogo das demais camadas do sistema. Dessa forma, será possível chegar cada vez mais próximo ao processo de implementação final do sistema. A camada de vigilância foi desenvolvida com o objetivo de estudar, principalmente, o comportamento do agente de captura de pacotes, visando a obtenção dos dados necessários para a avaliação de técnicas de captura empregadas em SDIs.

A técnica avaliada no projeto estuda a possibilidade de efetuar a captura de pacotes distribuída pela rede, através da utilização de um agente de distribuição e filtragem móvel denominado agente de pré-seleção de dados. A avaliação dos dados capturados pelo agente estático é realizada por esse agente e limita-se a análise do cabeçalho dos pacotes. Além disso, efetua o disparo do agente de captura estático com um filtro inicial pré-definido ou ajustado pelo agente de interface, nas estações destinadas a vigilância.

A utilização de sockets TCP locais para realizar a comunicação entre o agente de captura e o agente de pré-seleção foi a alternativa escolhida para o intercâmbio de informações entre linguagens de programação distintas. Outra solução considerada baseia-se em Java Native Interface (JNI). Entretanto, o surgimento recente de uma alternativa para a captura de pacotes em Java pode representar uma alternativa mais atraente para a integração entre o agente de captura e o agente de pré-seleção. 
Uma sugestão para a continuidade desse trabalho refere-se ao desenvolvimento de considerações relativas a integração entre o agente de captura e o agente de pré-seleção. Qual seria a forma mais efetiva de comunicação entre esses agentes? Seria portar o módulo de captura para a biblioteca jpcap ou estudar a possibilidade de integração através do uso de JNI? Esse estudo leva a outra sugestão de trabalho posterior visando o estudo de desempenho relacionado a biblioteca de captura Java (jpcap) e a biblioteca de captura desenvolvida em linguagem C (libpcap). Vale a pena observar que, a jpcap é implementada tendo por base a libpcap (segundo consta no site oficial).

Além da análise de desempenho já citada, seria interessante realizar um novo planejamento do agente de captura de pacotes, de modo a considerar a implementação de uma solução verdadeiramente distribuída (pequenos agentes de captura móveis que coletem dados específicos ao longo da rede). Note que, no presente momento a solução utiliza uma entidade estática devido a impossibilidade de estudo anterior da biblioteca jpcap.

Além de considerar a topologia de captura de pacotes do sistema em questão, é necessário levar em conta a arquitetura da rede ao qual o sistema será aplicado. Em caso de o ambiente alvo ser uma rede broadcast, a aplicação do sistema é imediata. Não existe a necessidade de adaptações. Quando o sistema envolve uma estrutura que empregaswitches a situação muda. Nesse caso, ficou claro que não é possível utilizar uma solução baseada exclusivamente em software. Para explicitar isso, foi discutida a possibilidade de utilização de um agente de captura baseado em análise de vulnerabilidades.

Caso seja utilizado um dispositivo suscetível as vulnerabilidades descritas, é possível efetuar um processo de captura rudimentar independente de hardware. Entretanto, esse método quebra totalmente o paradigma utilizado pelos switches (segmentação de domínios). Com isso, o próximo passo foi explorar as características dehardware inerentes ao dispositivo, buscando uma forma de empregar o sistema discutido sem a necessidade de um processo traumático de adaptação ${ }^{1}$.

Os recursos fornecidos para o gerenciamento de segurança em redes, disponíveis em switches, limitam-se a utilização de portas de captura. As possíveis configurações para o redirecionamento de fluxo baseiam-se em monitoramento de portas, VLANs ou algum tipo de tráfego designado pelo usuário. Essas opções são bastante limitadas quando comparadas aos demais recursos de gerenciamento presentes no switch (como ACLs, SLB, etc.). O ideal seria que alguns desses recursos também estivessem disponíveis para a aplicação em portas de captura, de forma a facilitar o trabalho de filtragem desenvolvido pela sonda, ou mesmo integrar algumas das funções realizadas em software ao dispositivo.

Outro problema a ser abordado, que foge ao escopo deste trabalho, refere-se a limitação na interação de SDIs (comerciais ou acadêmicos) desenvolvidos por diferentes fontes (fabri-

\footnotetext{
${ }^{1}$ Isso dificilmente aconteceria devido a abordagem de agentes móveis que vem sendo utilizada.
} 
cantes ou instituições). Não é possível utilizar sistemas heterogêneos de maneira eficiente em um mesmo segmento (ou segmentos) de rede. Isso está diretamente relacionado a forma como os dados de intrusão são traduzidos pelo SDI. Torna-se necessário um mecanismo que permita essa interação entre os sistemas existentes, de forma a propiciar o compartilhamento de dados de intrusão. Com isso, o SDI passaria a assumir a figura de um 'data miner', onde sua função primordial seria coletar dados de comportamento anômalo ao longo da rede.

\subsection{Modelagem do SDI como um sistema de informação}

Sistemas detectores de intrusão (SDIs) não possuem mecanismos eficientes para o compartilhamento dos dados analisados entre si e entre outras ferramentas tradicionalmente utilizadas em segurança. Um projeto de doutorado (continuidade do trabalho desenvolvido em (Bernardes, 1999) encontra-se em andamento no grupo de segurança com o objetivo de utilizar as tecnologias de Data Warehousing e Data Mining no tratamento de dados, informações e conhecimento no processo de tomada de decisão em um ambiente de segurança computacional. O trabalho ainda está em sua fase inicial e não possui uma especificação formal até o momento.

Outra sugestão para um trabalho futuro, refere-se a utilização de um mecanismo para o compartilhamento de informações entre os diversos SDIs existentes. Essa característica pode ser obtida através do emprego do Intrusion Detection Message Exchange Format (IDMEF), que é um padrão que está sendo desenvolvido pelo Intrusion Detection Working Group IDWG $^{2}$, para reportar os eventos considerados suspeitos pelos SDIs.

Este padrão foi desenvolvido com base no XML (Extensible Markup Language), visando definir formatos de dados e procedimentos de intercâmbio para o compartilhamento de informações de interesse para SDIs, sistemas de resposta a incidentes e sistemas de gerenciamento em geral que tenham a necessidade de interagir com SDIs. Desta forma, torna-se possível conquistar a interação desejada. A utilização de um ambiente de rede formado por um panorama heterogêneo quanto aos SDIs utilizados não representaria mais um problema, permitindo que os pontos fortes de cada implementação sejam utilizados. A primeira iniciativa de utilização do padrão IDMEF para a geração de alertas, foi tomada por um sistema de detecção de intrusão open source denominado snort ${ }^{3}$. O estudo dos mecanismos de geração de mensagens utilizados por esse sistema podem representar o primeiro passo para a integração dessa característica ao SDI do ICMC.

\footnotetext{
${ }^{2}$ fonte: http://search.ietf.org/internet-drafts/draft-ietf-idwg-idmef-xml-05.txt

${ }^{3}$ Fonte: http://www.silicondefense.com/idwg/snort-idmef/ (visitado em 19/04/2001).
} 


\section{Referências Bibliográficas}

Ambrósio, D. (2002). Alternativas de Implementação de Reconhecimento de Padrões para Agentes Móveis em Ambiente de Segurança Computacional. Dissertação de mestrado em andamento, ICMC/USP.

Anonymous (1997). Maximum Security - A Hacker's Guide To Protecting Your Internet Site and Network. Sams net.

Axelsson, S. (2000). The base-rate fallacy and the difficulty of intrusion detection. ACM Transactions on Information and System Security, 3(3):186-205.

Bace, R. and Mell, P. (2001). NIST Special Publication on Intrusion Detection Systems. Primer on intrusion detection systems - guidance, Infidel, Inc., Scotts Valley, CA and National Institute of Standards and Technology. http://csrc.nist.gov/publications/nistpubs/800-31/sp800-31.pdf, visitado em 31/01/2002.

Balasubramaniyan, J., Garcia-Fernandez, J., Spafford, E., and Zamboni, D. (1998). An architecture for intrusion detection using autonomous agents. Technical report 98/05, COAST Laboratory. http://www.cerias.purdue.edu/homes/aafid/docs/tr9805.pdf, visitado em $31 / 01 / 2002$.

Bernardes, M. (1999). Avaliação do uso de agentes móveis em segurança computacional. Dissertação de mestrado, ICMC/USP.

Bonifácio, J. (1998). Sistemas de segurança distribuído: integração de firewalls com sistemas de detecção de intrusão. Dissertação de mestrado, ICMC/USP.

Bradley, K., Cheung, S., Puketza, N., Mukherjee, B., and Olsson, R. (1998). Detecting disruptive routers: a distributed network monitoring approach. In Proceedings of the 1998 IEEE Symposium on Security and Privacy.

Bradshaw, J. (1997). An Introduction to software agents AAAI Press/The MIT Press.

Cansian, A. (1997). Desenvolvimento de um Sistema Adaptativo de Detecção de Intrusos em redes de Computadores. Tese de doutorado, Instituto de Física de São Carlos - USP. 
Cheung, S., Crawford, R., Dilger, M., Frank, J., Hoagland, J., Levitt, K., Rowe, J., Staniford-Chen, S., Yip, R., and Zerkle, D. (1999). The design of GrIDS: a graph-based intrusion detection system. Technical report cse-99-2, Department of Computer Science, University of California at Davis, Davis, CA.

Cicilini, R. (1994). Desenvolvimento de um agente snmp para para plataformas rodando dos. Dissertação de mestrado, ICMC/USP.

Crosbie, M., Dole, B., Ellis, T., Irsul, I., and Spafford, E. (1996). IDIOT-Users Guide. Technical report tr-96-050, COAST Laboratory, Purdue University, Computer Science Building, West Lafayette, IN 47907- 1398. Visitado em 1/02/2002.

Crosbie, M. and Spafford, G. (1995). Active defense of a computer system using autonomous agents. Technical report 95-008, COAST Group, Department of Computer Sciences, Purdue University, West Lafayette,IN 47907-1398.

Denning, D., Edwards, D., Jagannathan, R., Lunt, T., and Neumann, P. (1987). A prototype IDES - a real-time intrusion detection expert system. Technical report, Computer Science Laboratory, SRI International.

Denning, D. and Neumann, P. (1985). Requirements and model for IDES - a real-time instrusion detection system. Technical report, Computer Science Laboratory, SRI International.

Extreme Networks, inc. (2000). ExtremeWare Software User Guide, Software version 6.1 Extreme Networks, inc., Santa Clara, California.

Farmer, D. and Venema, W. (1999). Computer forensics analysis class handouts. Online document. http://www.fish.com/forensics/, visitado em 01/02/2002.

Farmer, W., Guttman, J., and Swarup, V. (1996). Security for mobile agents: issues and requirements. In Proceedings of the 19th National Information Sytems Security Conference, vol. 2. National Institute of Standards and Technology.

Garfinkel, S. and Spafford, G. (1996). Pratical Unix \& Internet Security. Computer Security. O’Reilly \& Associates, Inc., second edition edition.

Heady, R., Luger, G., Maccabe, A., and Servilla, M. (1990). The Architecture of a Network Level Intrusion Detection System. Technical report, University of New Mexico, Department of Computer Science, Albuquerque, New Mexico.

Heberlein, L., Dias, G., Levitt, K., Mukherjee, B., Wood, J., and Wolber, D. (1990). A network security monitor. In Proceedings of the IEEE Symposium on Research in Security and Privacy. 
Hochberg, J., Jackson, K., Stallings, C., McClary, J., DuBois, D., and Ford, J. (1993). Nadir: an automated system for detecting network intrusion and misuse. Computers and Security, $12(3): 235-248$.

Hofmeyr, S. (1999). An immunological model of distributed detection and its application to computer security. Ph.d. thesis, University of New Mexico.

Hunt, C. (1998). TCP/IP Network Administration, chapter Chapter 6 and Chapter 11, pages 135,350. Help for UNIX System Administrators. O'Reilly \& Associates, Inc., 2 edition.

Ilgun, K., Kemmerer, R., and Porras, P. (1995). State transition analysis: A rule-based intrusion detection approach. IEEE Transactions on Software Engineering pages 181-199.

Jacobson, C., Leres, C., and Maccane, S. (1992). The bsd packet filter: A new architecture for user level packet capture. Lawrence Berkeley National Laboratory.

Kim, G. and Spafford, E. (1994). The design and implementataion of tripwire: a file system integrity checker. In The Second ACM Conference on Computer and Communications Security, Fairfax, VA. ACM Press, J. Stern (Ed.).

Kumar, S. (1995). Classiffication and detection of computer intrusions Ph.d. thesis, Purdue University, West Lafayette, IN 47907.

Kumar, S. and Spafford, E. (1995). A software architecture to support misuse intrusion detection. In Proceedings of the 18th National Information Security Conference, pages 194-204.

Lange, D. and Oshima, M. (1998). Programming and Deploying Java Mobile Agents with Aglets. Addison-Wesley, 2nd edition.

Lieira, J. (1995). Utilização de áudio e vídeo em ssistema sgerenciadores de rede de computadores. Dissertação de mestrado, ICMC/USP.

Lunt, T., Jagannathan, R., Lee, R., Listgarten, S., Edwards, D., Neumann, P., Javitz, H., and Valdes, A. (1988). Development and application of IDES: a real-time intrusion detection expert system. Technical report, SRI International.

Lunt, T., Tamaru, A., Gilham, F., Jagannathan, R., Neumann, P., Javitz, H., Valdez, A., and Garvey, T. (1992). A real-time intrusion detection expert system (IDES). Technical report, Computer Science Laboratory, SRI International, Menlo Park, California.

M. Crosbie, E. S. (1995). Defending a computer system using autonomous agents. In Proceedings of the 18th National Information Systems Security Conference 
Moraes, S. (1995). Voz em sistemas computacionais: projeto e implementação de módulos de processamento de voz em gerenciamento de redes. Dissertação de mestrado, ICMC/USP.

Morishita, F. (1997). Uma avaliação evolutiva dos protocolos de gerenciamento da internet: Snmpv1, snmpv2 e snmpv3. Dissertação de mestrado, ICMC/USP.

Mouro, R. (1997). Uma arquitetura operacional extensível para ferramentas de gerenciamento de redes. Dissertação de mestrado, ICMC/USP.

Mouro, R., Morishita, F., and Moreira, E. (1997). NetTracker: uma arquitetura operacional extensível para ferramentas de gerenciamento de redes. In Anais do $15^{\circ}$ simpósio brasileiro de redes de computadores, pages 64-174, ICMC/USP, São Carlos, SP.

Mukherjee, B., Heberlein, T., and Levitt, K. (1994). Network intrusion detection. IEEE Network, 8(3):26-41.

Neumann, P. and Porras, P. (1999). Experience with EMERALD to date. In Proceedings of the First USENIX Workshop on Intrusion Detection and Network Monitoring pages 73-80, Berkeley, CA.

Nwana, H. (1996). Software agents: An overview. Knowledge Engineering Revieu, 11(3):205-244. http://citeseer.nj.nec.com/nwana96software.html, visitado em 06/02/2002.

Oda, C. (1994). Desenvolvimento de um sistema monitor gráfico baseado em protocolo de gerenciamento snmp. Dissertação de mestrado, ICMC/USP.

Oyamada, M. and Ito, S. (1998). Aglets: Agentes móveis em java. Online document. www.inf.ufrgs.br/procpar/disc/cmp134/trabs/T2/981/Aglets/aglets.html, visitado em 06/02/2002.

Paxson, V. and Handley, M. (1999). Defending against nids evasion using traffic normalizers. Second International Workshop on the Recent Advances in Intrusion Detection http://downloads.securityfocus.com/library/p56-11.txt, visitado em 01/02/2002.

Pereira Filho, S. (2001). Avaliação para Ambientes Servidores para Agentes Móveis. Dissertação de mestrado, ICMC/USP.

Phung, M. (2000). Data mining in intrusion detection. Online document. http://www.sans.org/newlook/resources/IDFAQ/data_mining.htm, visitado em $01 / 02 / 2002$.

Polla, D., McConnell, J., Johnson, T., Marconi, J., Tobin, D., and Frincke, D. (1998). A frame work for cooperative intrusion detection. In Proceedings of the National Conference on Computer Security Systems, pages 361-373. 
Porras, P. and Neumann, P. (1997). EMERALD: Event monitoring enabling responses to anomalous live disturbances. In Proceedings of the 20th National Conference on Computer Security Systems, pages 719-729.

Ptacek, T. and Newsham, T. (1998). Evasion and Denial of Service: Eluding Network Intrusion Detection. Technical report, Secure Networks, Calgary, Alberta, Canada. http://secinf.net/info/ids/idspaper/idspaper.html, visitado em 01/02/2002.

Reami, E. (1998). Especificação e prototipagem de um ambiente de gerenciamento de segurança apoiado por agentes móveis. Dissertação de mestrado, ICMC/USP.

Sebring, M., Shellhouse, E., Hanna, M., and Whitehurst, R. (1988). Expert systems in intrusion detection: A case study. In Proceedings of the 11th National Computer Security Conference, pages 74-81, NIST-NCSC Baltimore, Maryland. National Institute of Standards and Technology.

Sipes, S. (2000). Intrusion detection faq, why you switched network isn't secure. SANS Institute resouces. http://www.sans.org/newlook/resources/IDFAQ/switched_network.htm, visitado em $25 / 01 / 2002$.

Snapp, S., Brentano, J., Dias, G., Goan, T., Heberlein, L., Ho, C. L., Levitt, K., Mukherjee, B., Smaha, S., Grance, T., Teal, D., and Mansur, D. (1991). Dids (distributed intrusion detection system) - motivation, architecture, and an early prototype. In Proceedings of the 14th National Computer Security Conference, Washington, DC.

Snapp, S., Smaha, S., Teal, D., and Grance, T. (1992). The dids (distributed intrusion detection system) prototype. In Proceedings of the USENIX Summer 1992 Technical Conference, San Antonio, TX.

Staniford-Chen, S., Cheung, S., Crawford, R., Dilger, M., Frank, J., Hoagland, J., Levitt, K., Wee, C., Yip, R., and Zerkle, D. (1996). Grids: a graph based intrusion detection system for large networks. In Proceedings of the 19th National Information Systems Security Conference, vol. 1. National Institute of Standards and Technology.

Sun Microsystems Inc. (1990). Network Information Tap - NIT (4P); SunOS 4.1.1 Reference Manual. Sun Microsystems Inc.

Tan, K., Thompson, D., and Ruighaver, A. (1999). Intrusion detection systems and a view to its forensic applications. Technical report, Department of Computer Science, University of Melbourne, Parkville 3052, Australia. http://www.cs.umbc.edu/cadip/docs/NetworkIntrusion/idsforensics.ps, visitado em 02/04/2002. 
Tavares, D., Castejon, E., Rossi, G., Cansian, A., and Moreira, E. (1999). ACME! (Advanced Counter-Measures Environment), Um Mecanismo de Captura e Análise de Pacotes para Aplicação em Detecção de Assinaturas de Ataque. Anais do Primeiro Simpósio de Segurança em Informática, pages 39-46.

Tavares, D., Pereira Filho, S., Bernardes, M., and Moreira, E. (2002). Especificação de agentes de captura para sistemas detectores de intrusão. Anais do II workshop em segurança de sistemas computacionais, pages 25-32.

Vitek, J. and Tschudin, C. (1997). Mobile Objects Systems: Towards the Programmable Internet, volume 1222. Springer-Verlag, Berlin, Germany.

White, G., Fisch, E., and Pooch, U. (1996). Cooperating security managers: a peer-based intrusion detection system. IEEE Network, pages 20-23.

Zamboni, D. and Spafford, E. (2000). Intrusion detection using autonomous agents. Computer Networks, 34(4):547-570. http://www.elsevier.nl/gej-ng/10/15/22/49/30/25/article.pdf, visitado em $31 / 01 / 2002$. 